SGW-47776

Revision 0

\title{
Aquifer Testing and Rebound Study in Support of the 100-H Deep Chromium Investigation
}

Prepared for the U.S. Department of Energy

Assistant Secretary for Environmental Management

Contractor for the U.S. Department of Energy

under Contract DE-AC06-08RL14788

chr2)

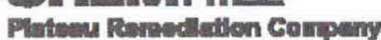

P.O. Box 1600

Richland, Washington 99352 
SGW-47776

Revision 0

\section{Aquifer Testing and Rebound Study in Support of the 100-H Deep Chromium Investigation}

Program/Project: S\&GRP

J. L. Smoot

CH2M HILL Plateau Remediation Company

Date Published

October 2010

Prepared for the U.S. Department of Energy

Assistant Secretary for Environmental Management

Contractor for the U.S. Department of Energy

under Contract DE-AC06-08RL14788

\section{BHFinHL}

Plateou Reresellmation Company

P.O. Box 1600

Richland, Washington

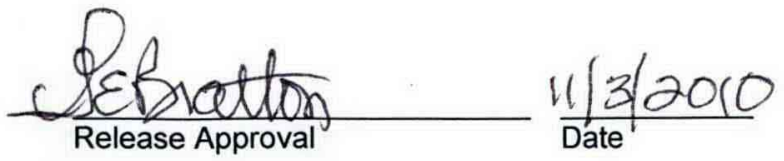


TRADEMARK DISCLAIMER

Reference herein to any specific commercial product, process,

or service by trade name, trademark, manufacturer, or

otherwise, does not necessarily constitute or imply its

endorsement, recommendation, or favoring by the United

States Government or any agency thereof or its contractors or subcontractors.

This report has been reproduced from the best available copy.

Printed in the United States of America

$\therefore \quad \cdots \quad \cdots$ 


\section{Contents}

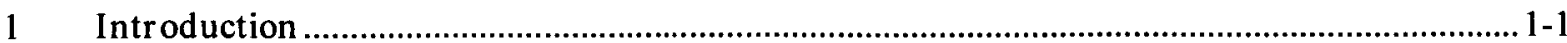

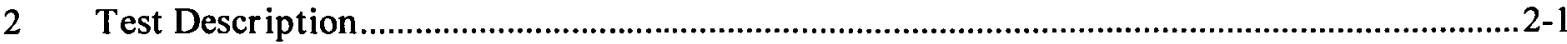

2.1 Water-Level and Barometric Measurements.................................................................... 2-3

2.2 Step-Drawdown Pumping Tests.................................................................................... 2-4

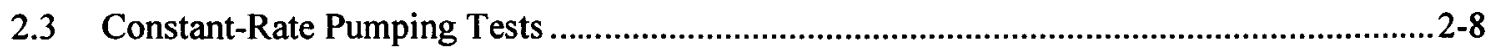

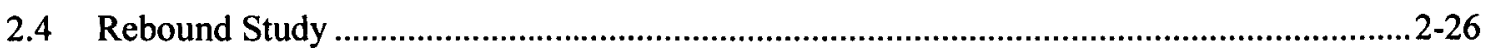

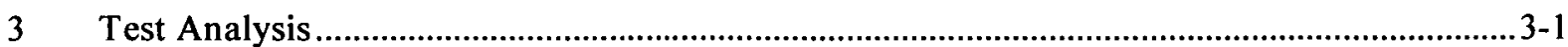

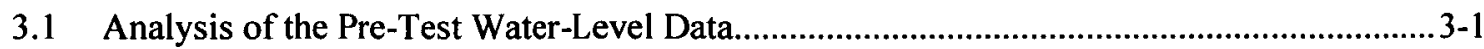

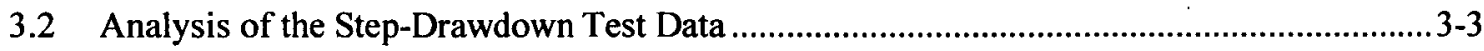

3.3 Analysis of the Constant-Rate Pumping Test Data ....................................................... 3-3

3.4 Comparison to Previous Testing Results............................................................................ 3-6

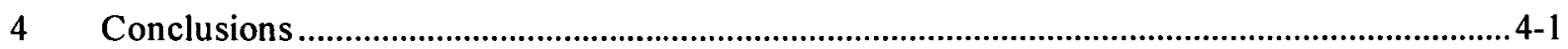

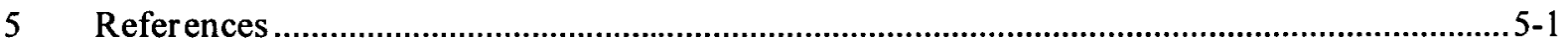

\section{Appendices}
A Test Well Construction Logs and Pump-and-Treat System Map ...............................................A-i
B Step-Drawdown and Constant-Rate Sample Results.
B-i

\section{Figures}

Figure 2-1. Location Map for 100-H Area Wells and Confined Aquifer Tests...................................2-2

Figure 2-2. Step-Drawdown Test Results for Well 199-H3-2C ...................................................2-5

Figure 2-3. Step-Drawdown Test Results for Well 199-H4-12C ....................................................2-6

Figure 2-4. Step-Drawdown Test Results for Well 199-H4-15CS ...............................................2-7

Figure 2-5. Hexavalent Chromium Results for Step-Drawdown Test for Well 199-H3-2C .................2-9

Figure 2-6. Hexavalent Chromium Results for Step-Drawdown Test for Well 199-H4-12C .............2-10

Figure 2-7. Hexavalent Chromium Results for Step-Drawdown Test

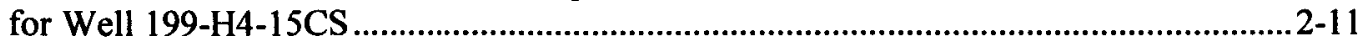

Figure 2-8. Hydrographs for Constant-Rate Pumping Test of Well 199-H3-2C ...............................2-14

Figure 2-9. Hydrograph for Constant-Rate Pumping Test of Well 199-H4-12C ...............................2-15

Figure 2-10. Hydrograph for Constant-Rate Pumping Test of Well 199-H4-15CS ..............................2-16

Figure 2-11. Drawdown Data for Constant-Rate Pumping Test of Well 199-H3-2C ..........................2-17

Figure 2-12. Drawdown Data for Constant-Rate Pumping Test of Well 199-H4-12C .......................2-18

Figure 2-13. Drawdown Data for Constant-Rate Pumping Test of Well 199-H4-15CS .......................2-19 
Figure 2-14. Recovery Data for Constant-Rate Pumping Test of Well 199-H3-2C.............................2-20

Figure 2-15. Recovery Data for Constant-Rate Pumping Test of Well 199-H4-12C ...........................2-21

Figure 2-16. Recovery Data for Constant-Rate Pumping Test of Well 199-H4-15CS ..........................2-22

Figure 2-17. Hexavalent Chromium Sample Results for Constant-Rate Pumping Test of Well 199-H3-2C.

Figure 2-18. Hexavalent Chromium Sample Results for Constant-Rate Pumping Test of Well 199-H4-12C

Figure 2-19. Hexavalent Chromium Sample Results for Constant-Rate Pumping Test of Well 199-H4-15CS.

Figure 2-20. Rebound Study Hexavalent Chromium Concentrations Near Well 199-H3-2C..............2-28

Figure 2-21. Rebound Study Hexavalent Chromium Concentrations Near Well 199-H4-12C.

Figure 2-22. Rebound Study Hexavalent Chromium Concentrations Near Well 199-H4-15CS.

Figure 2-23. Change in Hexavalent Chromium Concentration in 100-H Area Wells, August 25, 2009, Through March 24, 2010.

Figure 3-1. Pre-Test Hydrograph of Well 199-H4-12A and the Columbia River

\section{Tables}

Table 2-1. Summary of Pumping Well Information.............................................................................. 2-3

Table 2-2. Step-Drawdown Test Summary ................................................................................. 2-4

Table 2-3. Summary of Constant-Rate Pumping Tests Performed

Table 2-4. 100-H Area Hydrogeologic Details of Wells Pumped or Monitored During Testing...

Table 2-5. Rebound Study Well List

Table 3-1. Summary of Water-Level Response to Pre-Test River Stage Changes .............................3-3

Table 3-2. Estimates of Aquifer Transmissivity ................................................................................ 3-4

Table 3-3. Summary of Hydrologic Testing Performed in 1987 .....................................................6 
SGW-47776, REV. 0

\section{Terms}

$\begin{array}{ll}\text { bgs } & \text { below ground surface } \\ \text { CERCLA } & \begin{array}{l}\text { Comprehensive Environmental Response, Compensation, and Liability } \\ \text { Act of } 1980\end{array} \\ \text { OU } & \text { operable unit } \\ \text { P\&T } & \text { pump-and-treat } \\ \text { ppb } & \text { parts per billion } \\ \text { RUM } & \text { Ringold upper mud (unit) } \\ \text { SWL } & \text { static water level }\end{array}$


SGW-47776, REV. 0 


\section{Introduction}

The 100-HR-3 Groundwater Operable Unit (OU) second Comprehensive Environmental Response, Compensation, and Liability Act of 1980 (CERCLA) 5-year review (DOE/RL-2006-20, The Second CERCLA Five-Year Review Report for the Hanford Site) set a milestone to conduct an investigation of deep hexavalent chromium contamination in the sediments of the Ringold upper mud (RUM) unit, which underlies the unconfined aquifer in the 100-H Area. The 5-year review noted that groundwater samples from one deep well extending below the aquitard (i.e., RUM) exceeded both the groundwater standard of 48 parts per billion (ppb) (Ecology Publication 94-06, Model Toxics Control Act Cleanup Statute and Regulation) and the federal drinking water standard of $100 \mu \mathrm{g} / \mathrm{L}$ for hexavalent chromium. The extent of hexavalent chromium contamination in this zone is not well understood. Action 12-1 from the 5-year review is to "perform additional characterization of the aquifer below the initial aquitard."

Field characterization and aquifer testing were performed in the Hanford Site's 100-H Area to address this milestone. The aquifer tests were conducted to gather data to answer several fundamental questions regarding the presence of the hexavalent chromium in the deep sediments of the RUM and to determine the extent and magnitude of deeper contamination. The pumping tests were performed in accordance with the Description of Work for Aquifer Testing in Support of the 100-H Deep Chromium Investigation (SGW-41302). The specific objectives for the series of tests were as follows:

- Evaluate the sustainable production of the subject wells using step-drawdown and constant-rate pumping tests.

- Collect water-level data to evaluate the degree of hydraulic connection between the RUM and the unconfined (upper) aquifer (natural or induced along the well casing).

- Evaluate the hydraulic properties of a confined permeable layer within the RUM.

- Collect time-series groundwater samples during testing to evaluate the extent and persistence of hexavalent chromium in the deeper zones. Use data collected to refine the current conceptual model for the $100-\mathrm{H}$ Area unconfined aquifer and the RUM in this area.

- Evaluate the concentration "rebound" in the unconfined aquifer of hexavalent chromium and the contaminants of concern during shutdown of the extraction wells. Measure co-contaminants at the beginning, middle, and end of each pumping test.

The RUM is generally considered an aquitard in the 100-HR-3 OU; however, several water-bearing sand layers are present that are confined within the RUM. The current hydrogeologic model for the 100-H Area aquifer system portrays the RUM as an aquitard layer that underlies the unconfined aquifer, which may contain permeable zones, stringers, or layers. These permeable zones may provide pathways for chromium to migrate deeper into the RUM under certain hydrogeologic conditions. One condition may be the discharge of large volumes of cooling water that occurred near the former $\mathrm{H}$ Reactor, which caused a mound of groundwater to form 4.9 to $10.1 \mathrm{~m}$ ( 16 to $33 \mathrm{ft}$ ) above the natural water table. The cooling water reportedly contained 1 to $2 \mathrm{mg} / \mathrm{L}$ of hexavalent chromium for corrosion prevention.

Three alternate hypotheses for the introduction of hexavalent chromium into the RUM are as follows:

1. Local groundwater with higher concentrations of hexavalent chromium originating from reactor operations at $\mathrm{H}$ Reactor was driven by high heads from groundwater mounding in the unconfined aquifer into the RUM via permeable pathways in the upper surface of the RUM. 
2. Local groundwater with hexavalent chromium was introduced from the unconfined aquifer via well boreholes, either during drilling or as a result of poor well construction, allowing hydraulic communication between the unconfined aquifer and the RUM.

3. Hexavalent chromium migrated across the Horn area within the more permeable zones of the RUM.

The three wells used for the aquifer pumping tests (199-H3-2C, 199-H4-12C, and 199-H4-15CS) exhibit hexavalent chromium contamination in confined aquifer groundwater that may be the result of one of the mechanisms described above. The purpose of the aquifer testing was to gather data to help refine the conceptual model for the source of deep contamination, examine the potential hydraulic connection between the RUM and the unconfined aquifer, evaluate the hydraulic properties of a confined layer within the RUM, and indicate the extent of hexavalent chromium contamination in the RUM.

The results of this study, in conjunction with the recent Horn area investigation (DOE/RL-2008-42, Hydrogeological Summary Report for 600 Area Between 100-D and 100-H for the 100-HR-3 Groundwater Operable Unit), suggest that the first hypothesis is the most reasonable explanation. The results indicate persistent chromium concentrations over the duration of the tests, suggesting a large-scale emplacement of chromium. The concentration decreases upgradient toward the Horn area, suggesting that there is a limit on the eastward extent of contamination. This is consistent with the results of the Horn area investigation, which found locations in the same horizon in the Horn area with no chromium contamination. The potential for bad well construction to have generated the steady, persistent concentrations produced during the test seems unlikely, particularly given the upward groundwater gradient in the study area. 


\section{Test Description}

Testing was conducted at three 100-H Area wells (199-H3-2C, 199-H4-12C, and 199-H4-15CS) completed in the RUM that displayed elevated hexavalent chromium concentrations above the $20 \mu \mathrm{g} / \mathrm{L}$ remedial action objective. The locations for the three wells are illustrated in Figure 2-1 and described in Table 2-1. Each subject test well is part of a group of wells screened at different depth intervals, either in the unconfined aquifer or at depth in the RUM. Borehole log/construction diagrams for the group of wells are presented in Appendix A.

The aquifer pumping tests included step-drawdown and constant-rate pumping tests performed at the three 100-H Area wells during the summer and fall of 2009. A step-drawdown test is typically conducted prior to a constant-rate pumping test to obtain information to design the constant-rate test, determine well efficiencies, and estimate sustainable well production. The step-drawdown tests consisted of a series of three discharge steps in which pumping rates were increased for each step. Constant-rate pumping tests consisted of pumping at a steady discharge rate at each well for an extended period of time and monitoring changes in hexavalent chromium concentrations and water levels.

The 100-H Area pump-and-treat (P\&T) system was partially shut down on August 20, 2009, to facilitate pumping and characterization work. The shutdown occurred one month prior to beginning the first constant-rate pumping test. The 100-H Area P\&T system includes four wells from the 100-D Area that are linked by a transfer line. In granting approval for the study, the Washington State Department of Ecology directed that pumping continue from the 100-D Area wells. Therefore, prior to performing pumping tests at wells $199-\mathrm{H} 3-2 \mathrm{C}$ and $199-\mathrm{H} 4-12 \mathrm{C}$, approximately $265 \mathrm{~L} / \mathrm{min}(70 \mathrm{gal} / \mathrm{min})$ of treated water from the 100-D Area was injected into well 199-H4-17.

The following list summarizes the start and stop times for the different pumping tests and related operations in 2009:

- Normal P\&T operations: January 1 through August 20

- $\quad$ Rebound test period: August 20 through November 11

- Well 199-H4-17 injection: January 1 through November 3 (15:19 hours)

- Normal P\&T operations: November 11 to present

- $\quad$ Step-drawdown pumping tests:

- 199-H3-2C: September 16 (09:15 to $15: 14$ hours)

- 199-H4-12C: September 16 (09:10 to 15:05 hours)

- 199-H4-15CS: October 27 (07:38 to 14:46 hours)

- Constant-rate pumping tests:

- 199-H3-2C: September 21 (09:25 hours) through November 3 (15:13 hours) (62,268-min test)

- 199-H4-12C: September 21 (09:40 hours) through November 3 (15:16 hours) (62,256-min test)

- 199-H4-15CS: October 28 (09:00 to 14:45 hours) (345-min test). 


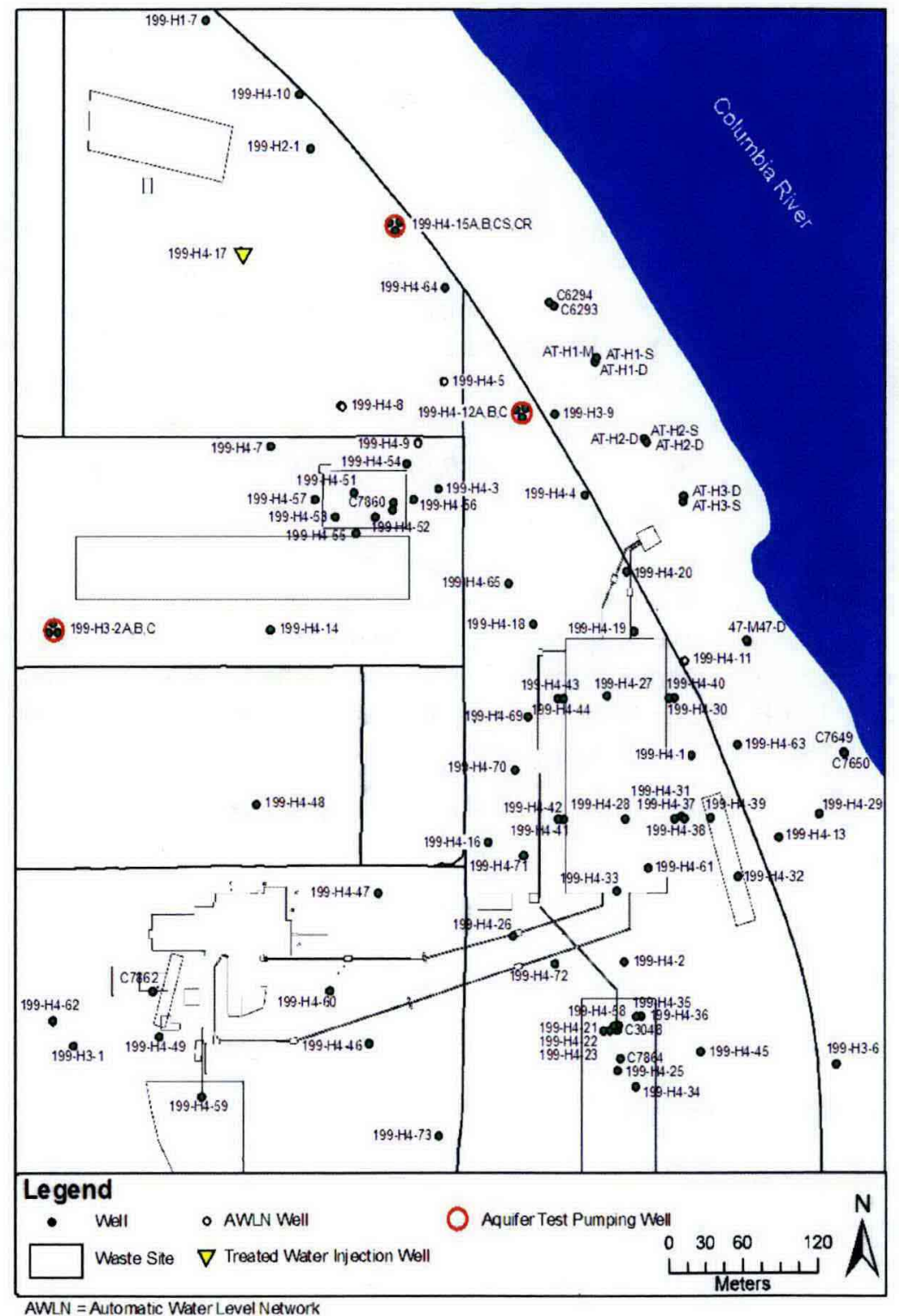

AWLN = Automatic Water Level Network

Figure 2-1. Location Map for 100-H Area Wells and Confined Aquifer Tests 
Table 2-1. Summary of Pumping Well Information

\begin{tabular}{|l|c|c|c|c|c|}
\hline Well Name & $\begin{array}{c}\text { Casing } \\
\text { Diameter } \\
\text { (in.) }\end{array}$ & $\begin{array}{c}\text { Screen } \\
\text { Interval } \\
\text { (ft bgs) and } \\
\text { Slot Size (in.) }\end{array}$ & $\begin{array}{c}\text { SWL Prior to } \\
\text { Pumping Test } \\
\text { (ft bgs) } \\
\text { and Date }\end{array}$ & $\begin{array}{c}\text { Distance to } \\
\text { Shoreline of } \\
\text { Columbia River } \\
\text { (ft) }\end{array}$ & $\begin{array}{c}\text { Hydrostratigraphic } \\
\text { Unit* }\end{array}$ \\
\hline 199-H3-2C & 6 & $\begin{array}{c}100 \text { to } 110 \\
(0.010)\end{array}$ & $\begin{array}{c}40.95 \\
9 / 21 / 2009\end{array}$ & 1,820 & RUM \\
\hline 199-H4-12C & 6 & $\begin{array}{c}72 \text { to } 82 \\
(0.010)\end{array}$ & $\begin{array}{c}38.84 \\
9 / 21 / 2009\end{array}$ & 440 & RUM \\
\hline 199-H4-15CS & 2 & $\begin{array}{c}78 \text { to } 80 \\
(0.020)\end{array}$ & $\begin{array}{c}32.82 \\
10 / 28 / 2009\end{array}$ & 470 & RUM \\
\hline
\end{tabular}

* See well logs in Appendix A and Table 2-4 for specific RUM confined aquifer zone descriptions.

Step-drawdown pumping tests were conducted at wells $199-\mathrm{H} 3-2 \mathrm{C}$ and $199-\mathrm{H} 4-12 \mathrm{C}$ on September 16, 2009, and a step-drawdown test was conducted at well 199-H4-15CS on October 27, 2009. Constant-rate pumping tests occurred at wells 199-H3-2C and 199-H4-12C starting September 21, 2009, and pumping stopped November 3, 2009, for a total duration of 43.2 days each. Water pumped from these two wells was directed to the 100-H Area P\&T system for treatment and injection during the test period. The constant-rate pumping test at well 199-H4-15CS occurred October 28, 2009, for a duration of 0.24 days (345 minutes). The pumped groundwater from well 199-H4-15CS was temporarily stored in a $18,927 \mathrm{~L}(5,000$-gal) tank for subsequent disposal to the P\&T system.

Groundwater pumped from wells 199-H3-2C and 199-H4-2C was directed to the groundwater treatment facility, and the treated water was combined with water already being injected into well 199-H4-17. During testing of the two wells, an average of 378.5 to $416.4 \mathrm{~L} / \mathrm{min}$ (100 to $110 \mathrm{gal} / \mathrm{min}$ ) was injected into shallow aquifer at well 199-H4-17. The injection at well 199-H4-17 ceased on November 3, 2009, at 3:19 p.m., shortly after the conclusion of the pumping tests for wells 199-H3-2C and 199-H4-12C. Pumping and injection at the 100-H Area P\&T system resumed on approximately November 11, 2009. Thus, the general rebound test period occurred between August 20 and November 11, 2009, with no pumping or injection occurring between November 3 at 3:19 p.m. and November 11, and limited pumping and injection occurred between August 20 and November 3, 2009.

\subsection{Water-Level and Barometric Measurements}

Water-level measurements in the pumping and observation wells were conducted using pressure transducers in accordance with SGW-41302, except during step-drawdown tests at wells 199-H3-2C and 199-H4-12C. During these tests, the range of pressures exceeded the transducer specifications, so measurements were made manually using an electronic tape. Pressure transducers were successfully used during constant-rate tests at these wells.

River stage was monitored using a pressure transducer in the Columbia River at the former $100-\mathrm{H}$ Area pump station. Barometric effects were monitored using the barometer contained within the data logger. Barometric pressure records from the Hanford Site Meteorological Station were also obtained and examined for the test period. Barometric effects and barometric efficiency were not calculated from the pre-test data because water-level effects from changes in the Columbia River stage were determined to overwhelm any barometric effects, making estimation of barometric efficiency problematic. 


\subsection{Step-Drawdown Pumping Tests}

Step-drawdown pumping tests were performed at wells 199-H3-2C, 199-H4-12C, and 199-H4-15CS to determine the optimum pumping rate for the constant-rate pumping tests. Each well was pumped at three different pumping rates, with the pumping rates ranging from 7.6 to $152.2 \mathrm{~L} / \mathrm{min}$ ( 2 to $40.2 \mathrm{gal} / \mathrm{min}$ ). One goal of step-drawdown testing is to determine the optimum pumping rate for the long-term pumping tests. SGW-41302 suggested that the constant-rate tests use approximately 50 percent of available drawdown. Available drawdown for a confined aquifer well is defined as the length between static water level and the top of the well screen. Table 2-2 summarizes the results of the step-drawdown tests, including calculated specific capacity (gal $/ \mathrm{min} / \mathrm{ft}$ of drawdown) for the different pumping rates. Step-drawdown graphs for pumping wells 199-H3-2C, 199-H4-12C, and 199-H4-15CS are presented in Figures 2-2 through 2-4. These graphs illustrate the relative amount of drawdown caused by short-term pumping at each of the three wells.

Table 2-2. Step-Drawdown Test Summary

\begin{tabular}{|c|c|c|c|c|}
\hline $\begin{array}{c}\text { Discharge } \\
\text { Rate } \\
\text { (gal/min) }\end{array}$ & $\begin{array}{c}\text { Pumping } \\
\text { Duration } \\
\text { (min) }\end{array}$ & $\begin{array}{c}\text { Final } \\
\text { Drawdown } \\
\text { (ft) }\end{array}$ & $\begin{array}{c}\text { Final Specific } \\
\text { Capacity } \\
\text { (gal/min/ft } \\
\text { Drawdown) }\end{array}$ & $\begin{array}{c}\text { Percentage } \\
\text { Available } \\
\text { Drawdown } \\
\text { Used }\end{array}$ \\
\hline \multicolumn{5}{|c|}{ Well 199-H3-2C } \\
\hline 10.3 & 102 & 9.6 & 1.07 & 17 \\
\hline 20.6 & 102 & 18.20 & 1.13 & 32 \\
\hline 40.2 & 104 & 36.84 & 1.09 & 65 \\
\hline \multicolumn{5}{|c|}{ Well 199-H4-12C } \\
\hline 5.5 & 111 & 3.6 & 1.53 & 12 \\
\hline 10 & 116 & 6.57 & 1.52 & 22 \\
\hline 20.2 & 58 & 13.27 & 1.52 & 44 \\
\hline \multicolumn{5}{|c|}{ Well 199-H4-15CS } \\
\hline 2 & 14 & 1.92 & 1.04 & 4 \\
\hline 3 & 116 & 2.65 & 1.13 & 6 \\
\hline 4 & 149 & 3.39 & 1.18 & 8 \\
\hline
\end{tabular}




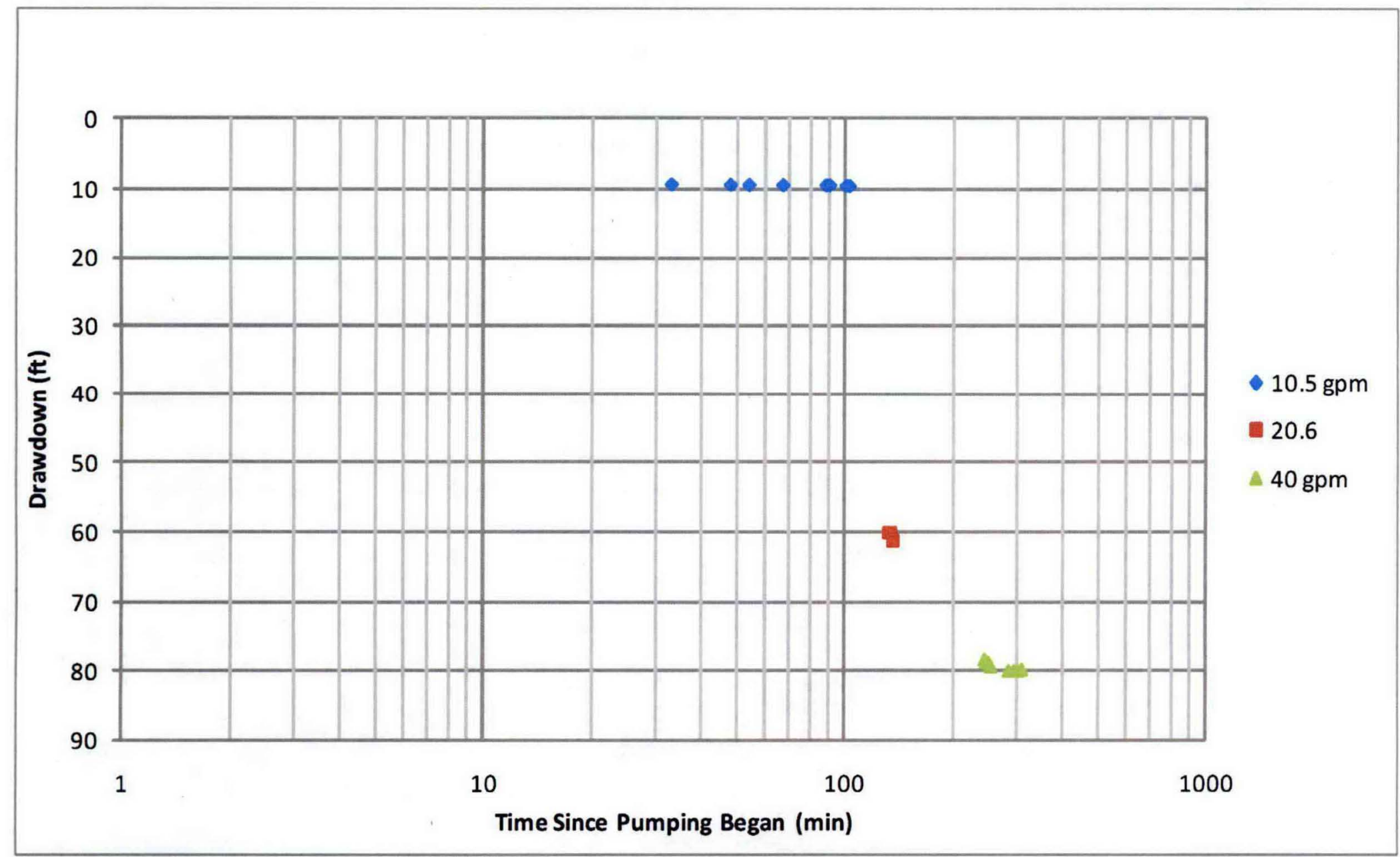

Figure 2-2. Step-Drawdown Test Results for Well 199-H3-2C 


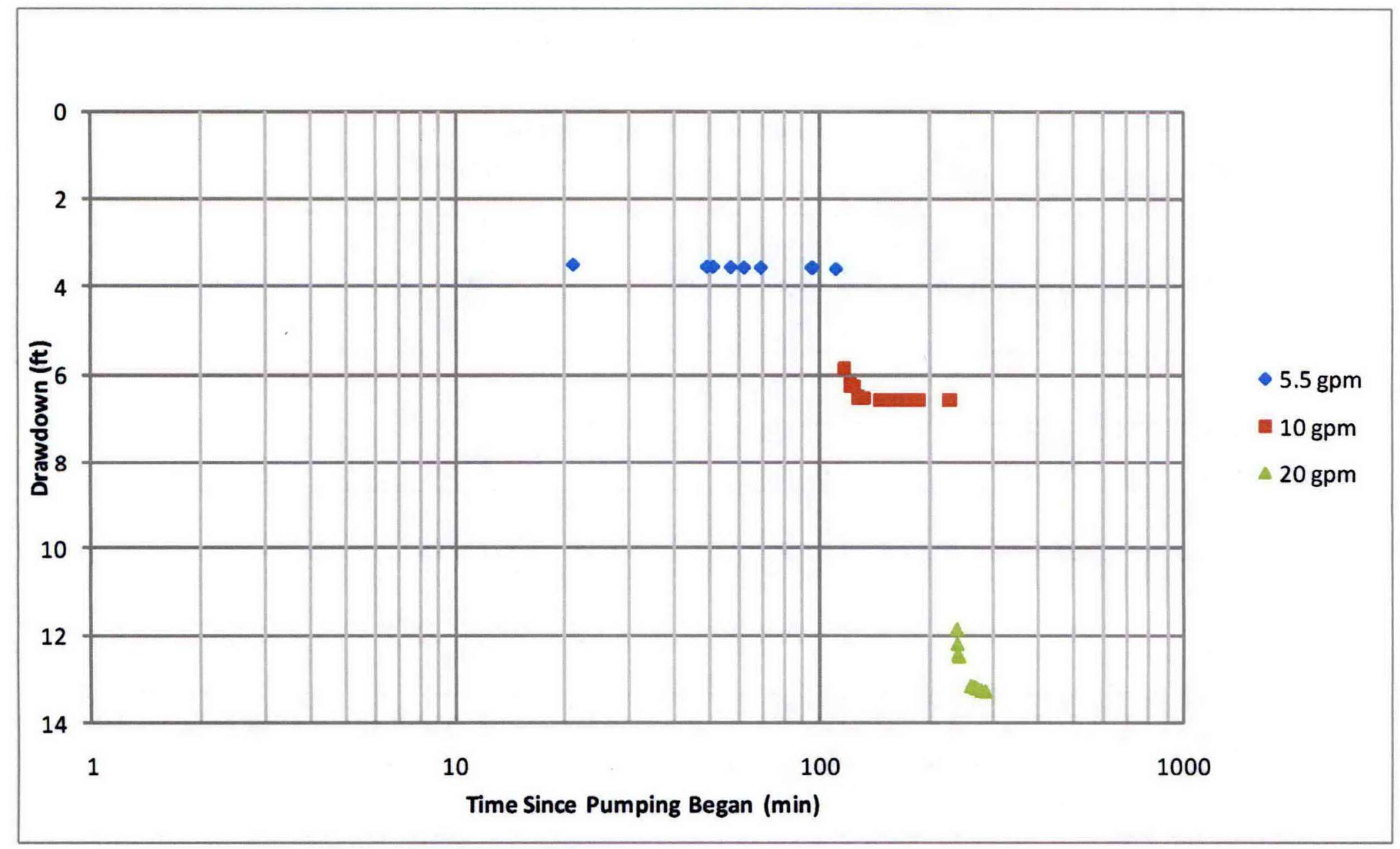

Figure 2-3. Step-Drawdown Test Results for Well 199-H4-12C 


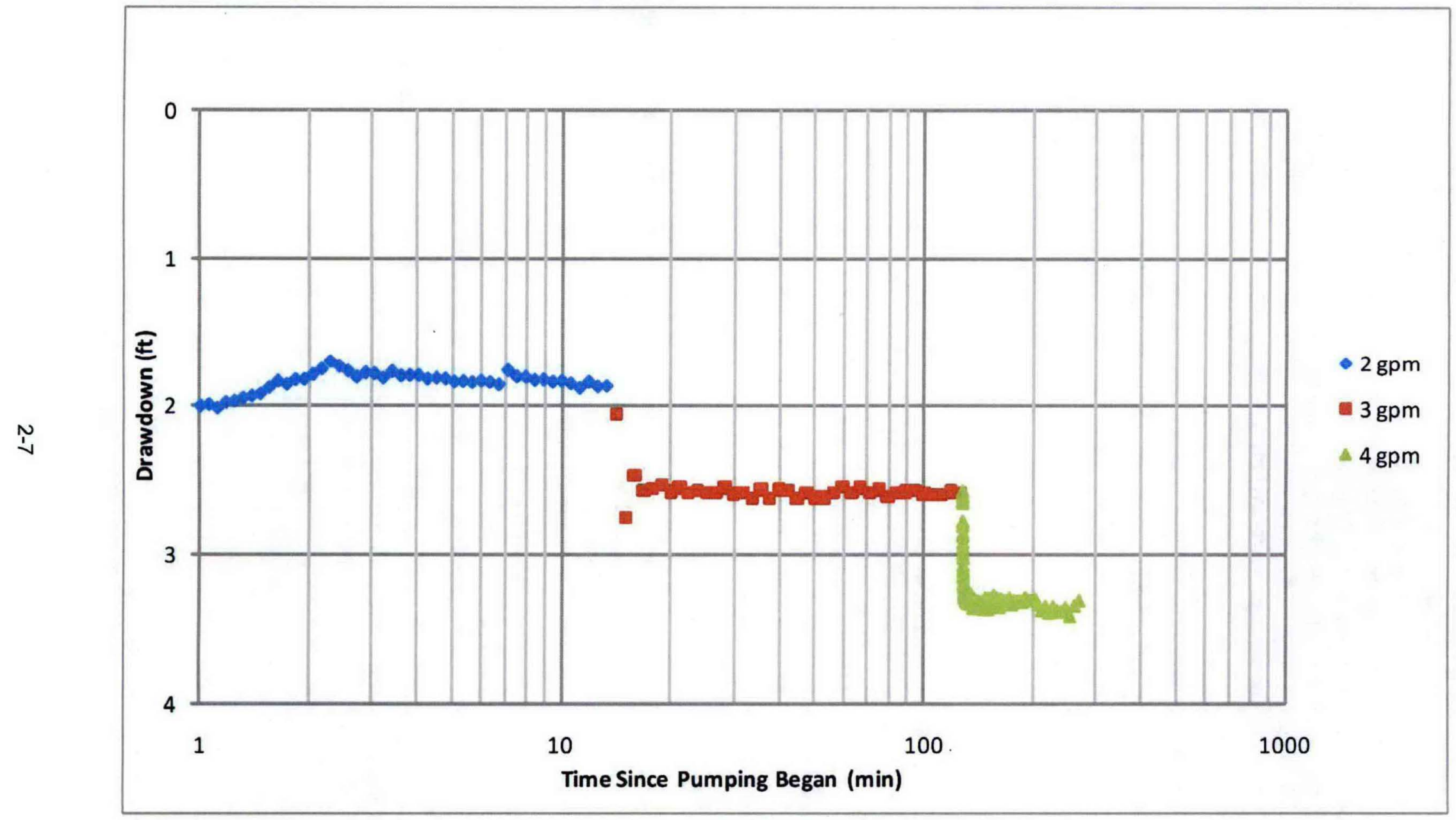

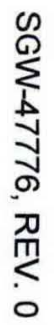

Figure 2-4. Step-Drawdown Test Results for Well 199-H4-15CS 
Water samples for field measurement of hexavalent chromium in wells 199-H3-2C, 199-H4-12C, and 199-H4-15CS were collected from sample ports as routine operation samples (as specified in procedure GRP-FS-04-G-001, Chromium Analysis of Water Samples at Pump and Treat Facilities) during the step-drawdown tests. Hexavalent chromium was measured in the field with a Hach ${ }^{\circledR} 1$ test kit, and the results are shown in Figures 2-5 through 2-7 for each of the wells. Field parameters (turbidity, specific conductivity, temperature, and $\mathrm{pH}$ ) were also measured in the field at each pumping well. Tables $\mathrm{B}-1$ through B-3 in Appendix B present the sample results for each pumping well during the step-drawdown tests; however, no water chemistry or water-level measurements were performed at nearby wells during step-drawdown testing.

\subsection{Constant-Rate Pumping Tests}

The constant-rate pumping tests at wells $199-\mathrm{H} 3-2 \mathrm{C}$ and 199-H4-12C were conducted simultaneously from September 21 through November 3, 2009, for a pumping period of 43.2 days each. A constant-rate pumping test of well 199-H4-15CS was conducted on September 28, 2009, for a pumping period of 0.24 days (5 hours 45 minutes). A shorter duration test at well 199-H4-15CS was conducted due to limitations of the pumping equipment and the temporary water storage reservoir.

Measurements of discharge were continually monitored at the pumping and observation wells for all three constant-rate discharge tests. Table 2-3 presents a summary of the tests performed, including final specific capacity and the observation wells monitored. General well and aquifer details for the pumping and observation wells are presented in Table 2-4, including radial distance to the observation wells. All unconfined observation wells were located within 7.3 to $7.9 \mathrm{~m} \mathrm{(24} \mathrm{to} 26 \mathrm{ft})$ of the pumping well. The term "observation well" in this document describes any well used to observe possible water-level response to pumping at a nearby test well. None of the nearby observation wells used during the three pumping tests monitored the same aquifer zone tested by the pumping wells; shallow unconfined aquifer wells were monitored near RUM pumping wells 199-H3-2C and 199-H4-12C, and both shallow unconfined aquifer and deeper confined zones within the RUM were monitored near pumping well 199-H4-15CS.

The three tests are illustrated three different ways. Arithmetic plots of the water levels in the pumping and nearby observation wells are presented with Columbia River stage in Figures 2-8 through 2-10. Semi-log graphs of water-level drawdown are presented in Figures 2-11 through 2-13. Semi-log graphs of water-level recovery are presented in Figures 2-14 through 2-16.

Time-series groundwater samples were collected for hexavalent chromium analysis from each of the pumped wells. Hexavalent chromium concentrations versus time are illustrated in Figures 2-17 through 2-19. Samples were collected at the well heads and measured using a field test kit for hexavalent chromium. Field parameters (turbidity, specific conductivity, temperature, and $\mathrm{pH}$ ) were also measured in the field at each pumping well. Additional samples for laboratory analysis were collected at 30 minutes, 8 hours, 10 days, and 20 days. Tables B- 4 through B-6 in Appendix B present the analytical results for the each of the wells during the constant-rate tests.

\footnotetext{
$1 \mathrm{Hach}^{\circledR}$ is a registered trademark of the Hach Company, Loveland, Colorado.
} 


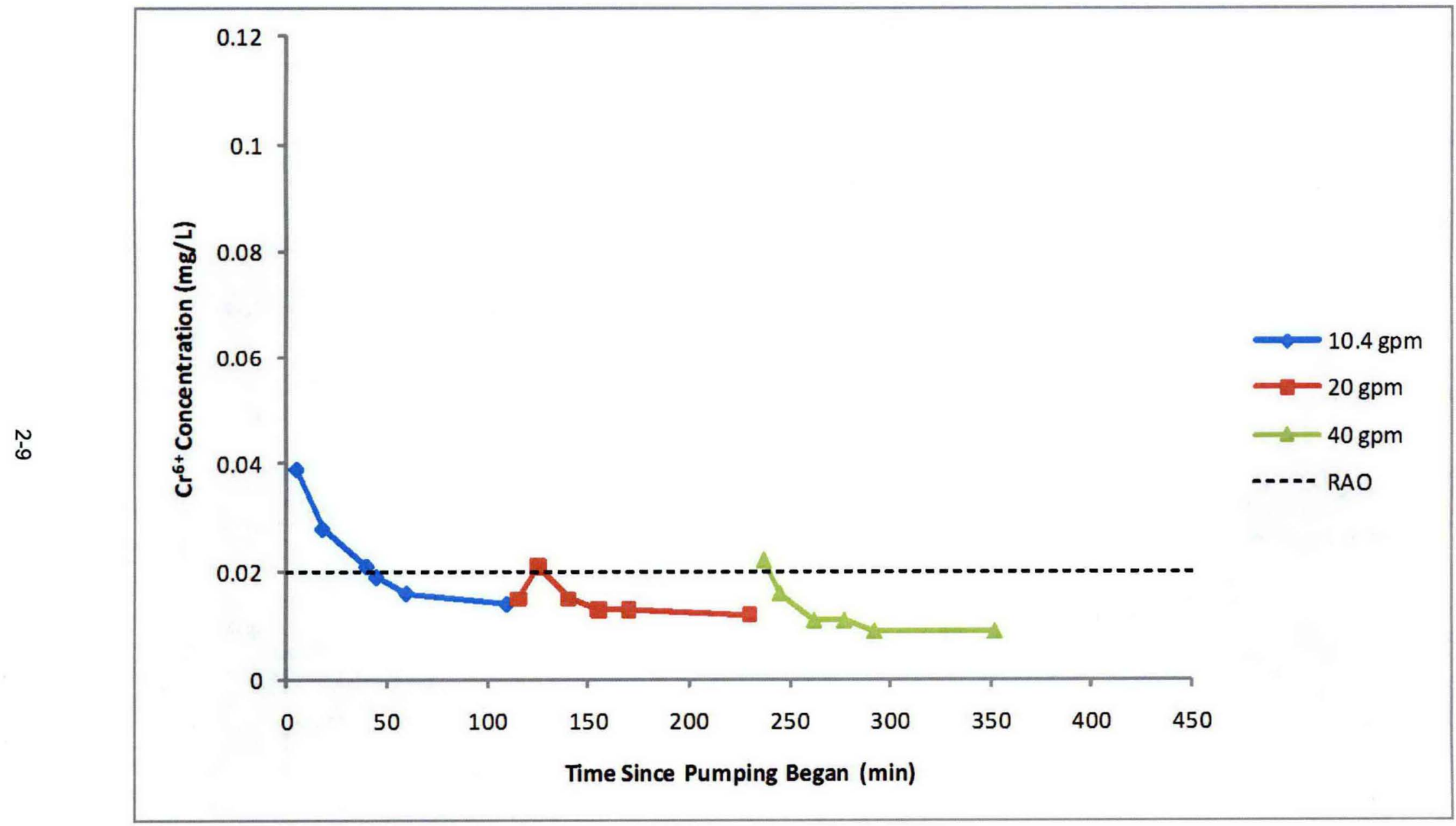

Figure 2-5. Hexavalent Chromium Results for Step-Drawdown Test for Well 199-H3-2C 


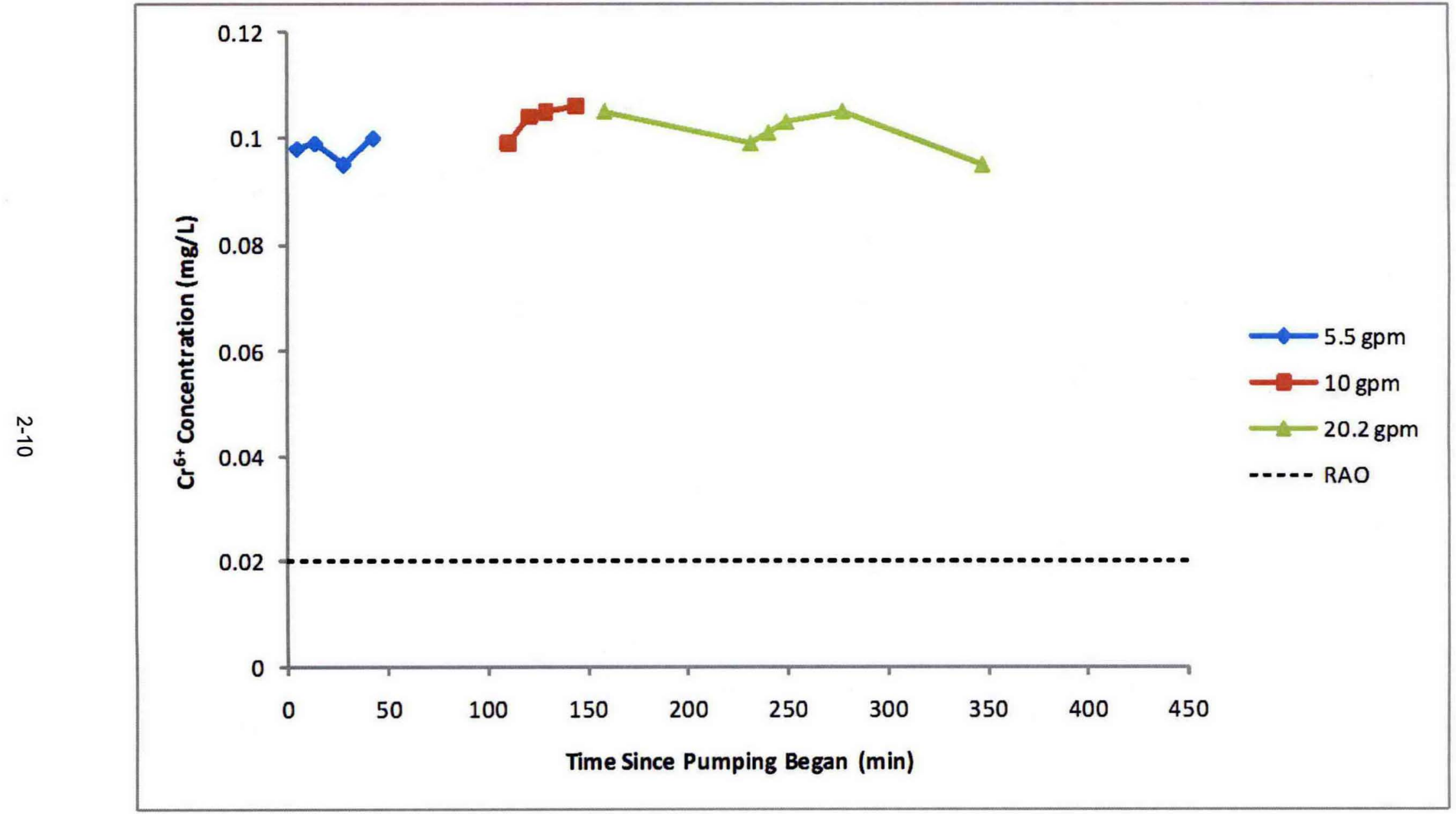

Figure 2-6. Hexavalent Chromium Results for Step-Drawdown Test for Well 199-H4-12C 


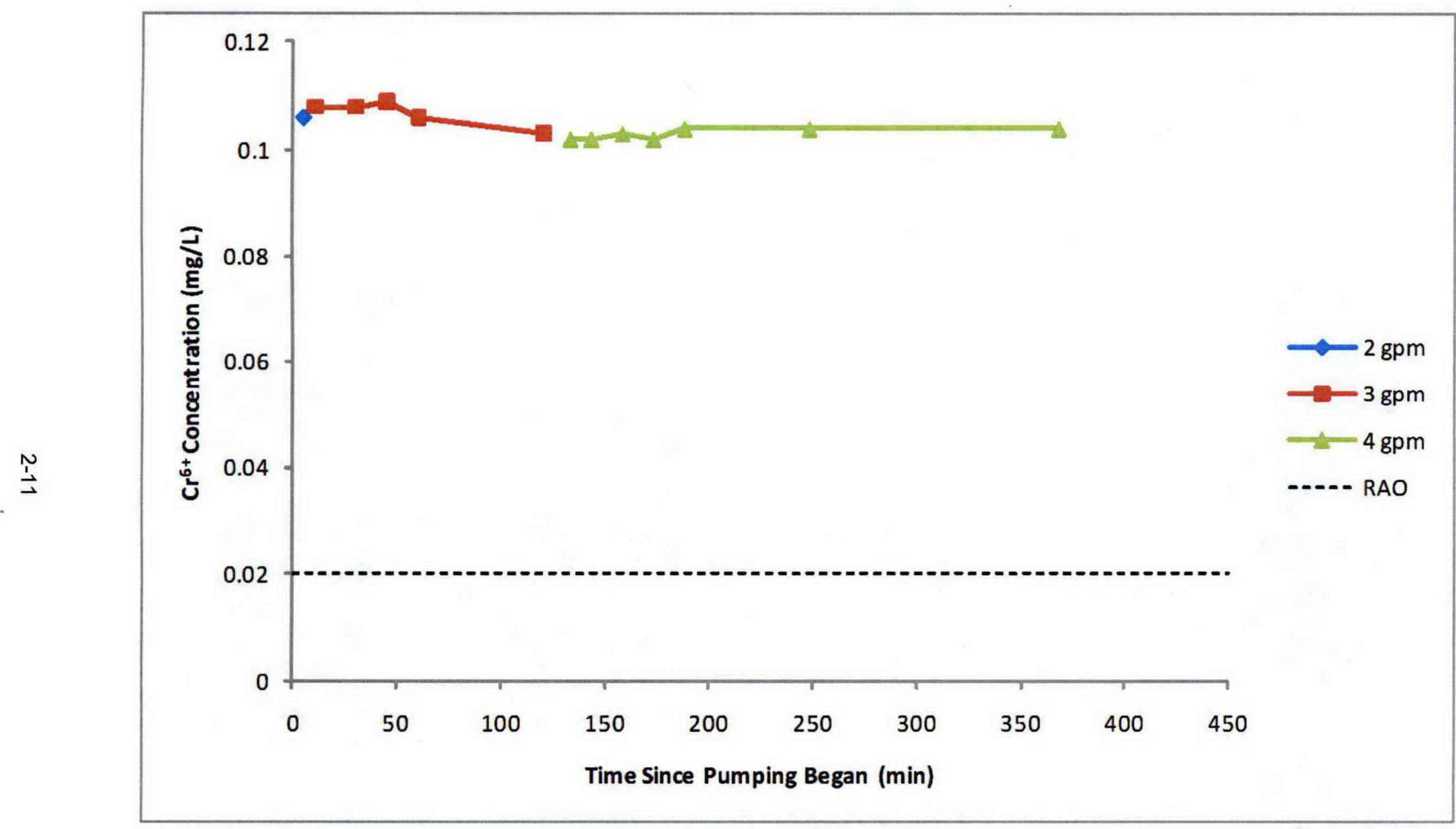

Figure 2-7. Hexavalent Chromium Results for Step-Drawdown Test for Well 199-H4-15CS 
Table 2-3. Summary of Constant-Rate Pumping Tests Performed

\begin{tabular}{|c|c|c|c|c|c|c|c|}
\hline $\begin{array}{c}\text { Pumping } \\
\text { Well Name }\end{array}$ & $\begin{array}{c}\text { Test Start } \\
\text { Date }\end{array}$ & 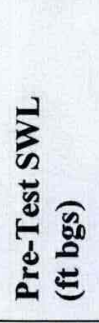 & 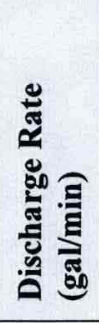 & 递 & 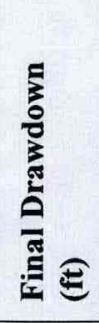 & 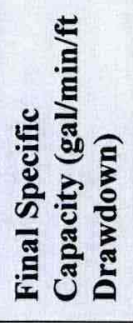 & $\begin{array}{l}\text { Observation } \\
\text { Well Names Associated } \\
\text { with Pumping Test }\end{array}$ \\
\hline $199-\mathrm{H} 3-2 \mathrm{C}$ & $9 / 21 / 2009$ & 40.95 & 40 & 43.2 & 48.77 & 0.82 & 199-H3-2A and 199-H3-2B \\
\hline $199-\mathrm{H} 4-12 \mathrm{C}$ & $9 / 21 / 2009$ & 38.84 & 20 & 43.2 & 14.56 & 1.28 & $199-\mathrm{H} 4-12 \mathrm{~A}$ and $199-\mathrm{H} 4-12 \mathrm{~B}$ \\
\hline $199-\mathrm{H} 4-15 \mathrm{CS}$ & $10 / 28 / 2009$ & 32.82 & 4 & 0.24 & 3.51 & 1.05 & $\begin{array}{l}\text { 199-H4-15A, 199-H4-15CP, } \\
199-\mathrm{H} 4-15 \mathrm{CQ} \text {, and } \\
199-\mathrm{H} 4-15 \mathrm{CR}\end{array}$ \\
\hline
\end{tabular}

Measured concentrations during the pumping test exhibited sustained concentrations that were constant or only slightly increasing. The highest concentrations (approximately $0.11 \mathrm{mg} / \mathrm{L}$ ) were measured closest to the Columbia River at wells $199-\mathrm{H} 4-15 \mathrm{CS}$ and $199-\mathrm{H} 4-12 \mathrm{C}$, and lower concentrations (0.02 to $0.05 \mathrm{mg} / \mathrm{L}$ ) were measured further inland at well 199-H3-2C. Assuming H Reactor cooling water hexavalent chromium concentrations of 0.7 to $1.0 \mathrm{mg} / \mathrm{L}$, the observed concentrations are on the order of one-tenth to one-thirtieth of the likely initial concentration, indicating mixing with groundwater in both the unconfined aquifer and underlying RUM. These concentrations seem consistent with a cooling water origin.

Three alternate hypotheses for the introduction of hexavalent chromium into the RUM, previously described in Chapter 1, include the following:

1. Local groundwater with higher concentrations of hexavalent chromium originating from reactor operations at $\mathrm{H}$ Reactor was driven by high heads from groundwater mounding in the unconfined aquifer into the RUM via permeable pathways in the upper surface of the RUM.

2. Local groundwater with hexavalent chromium was introduced from the unconfined aquifer via well boreholes, either during drilling or as a result of poor well construction, allowing hydraulic communication between the unconfined aquifer and the RUM.

3. Hexavalent chromium migrated across the Horn area within the more permeable zones of the RUM.

The last hypothesis seems unlikely, as the data from RUM sampling in the Horn area (DOE/RL-2008-42) show limited levels of hexavalent chromium (below the protective level for the Columbia River [20 ppb], the standard from Ecology Publication 94-06 [48 ppb], and the federal drinking water standard $[100 \mu \mathrm{g} / \mathrm{L}])$. 
Table 2-4. 100-H Area Hydrogeologic Details of Wells Pumped or Monitored During Testing

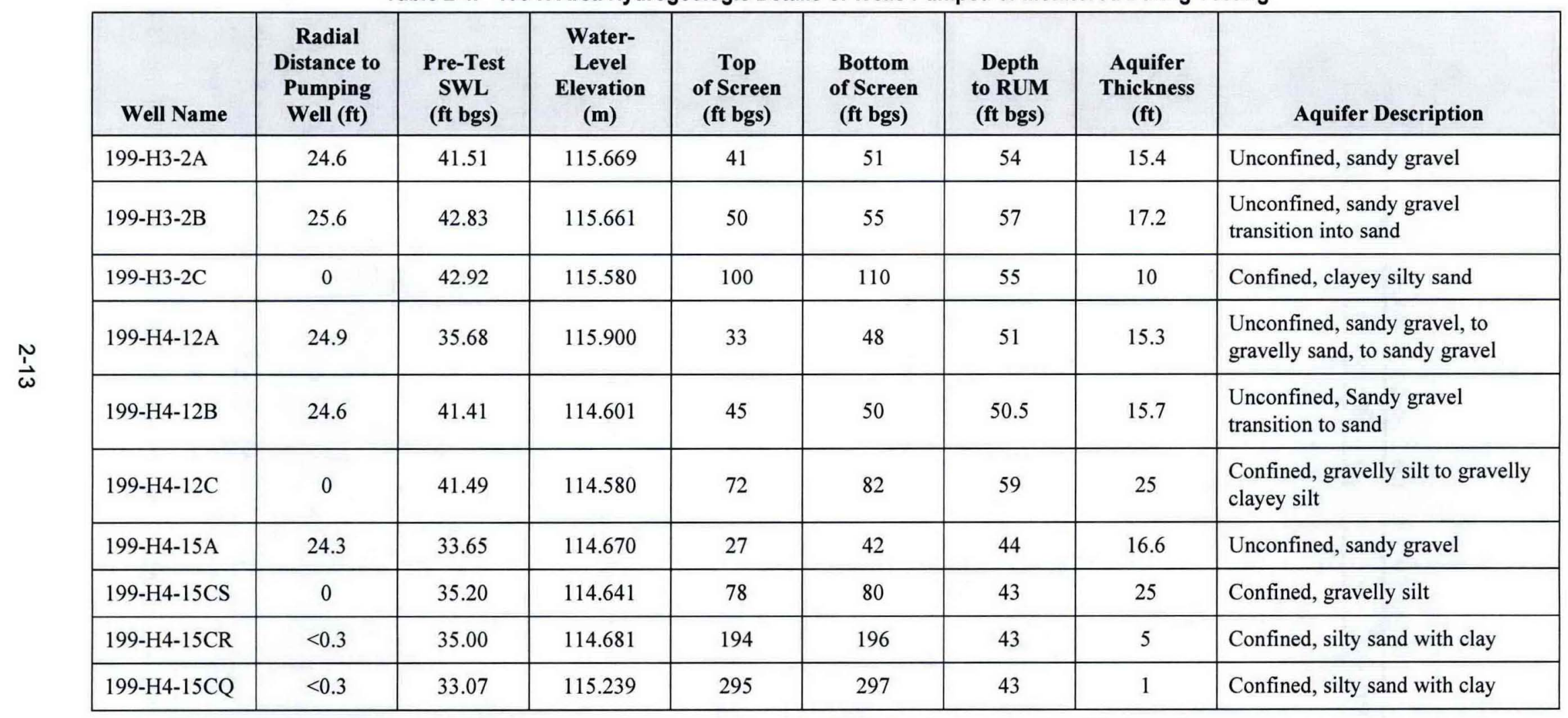

Notes: Piezometer 199-H4-15CP (completed in basalt, screened 325 to $327 \mathrm{ft}$ bgs and typically flows) was not monitored during testing. 

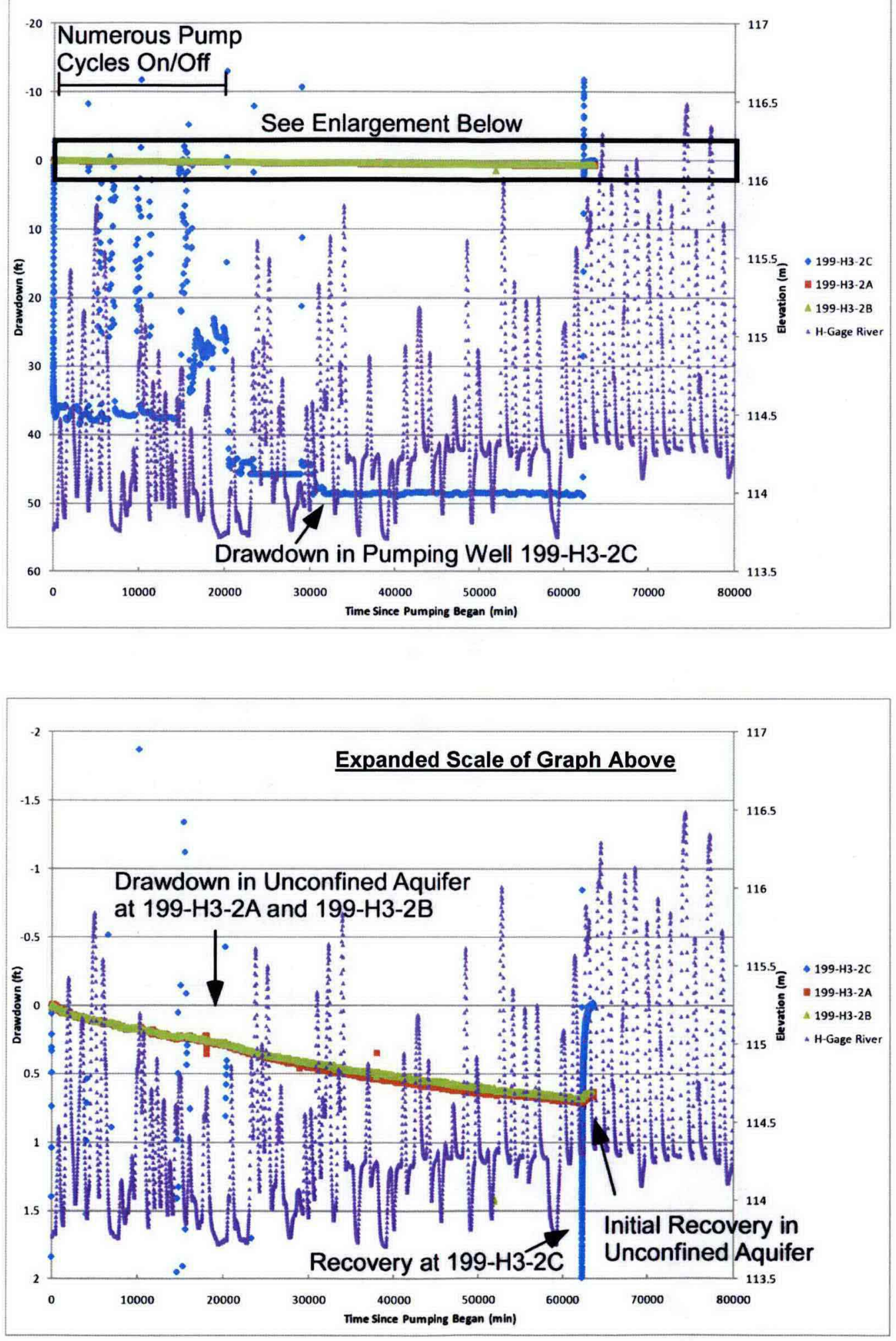

Figure 2-8. Hydrographs for Constant-Rate Pumping Test of Well 199-H3-2C 


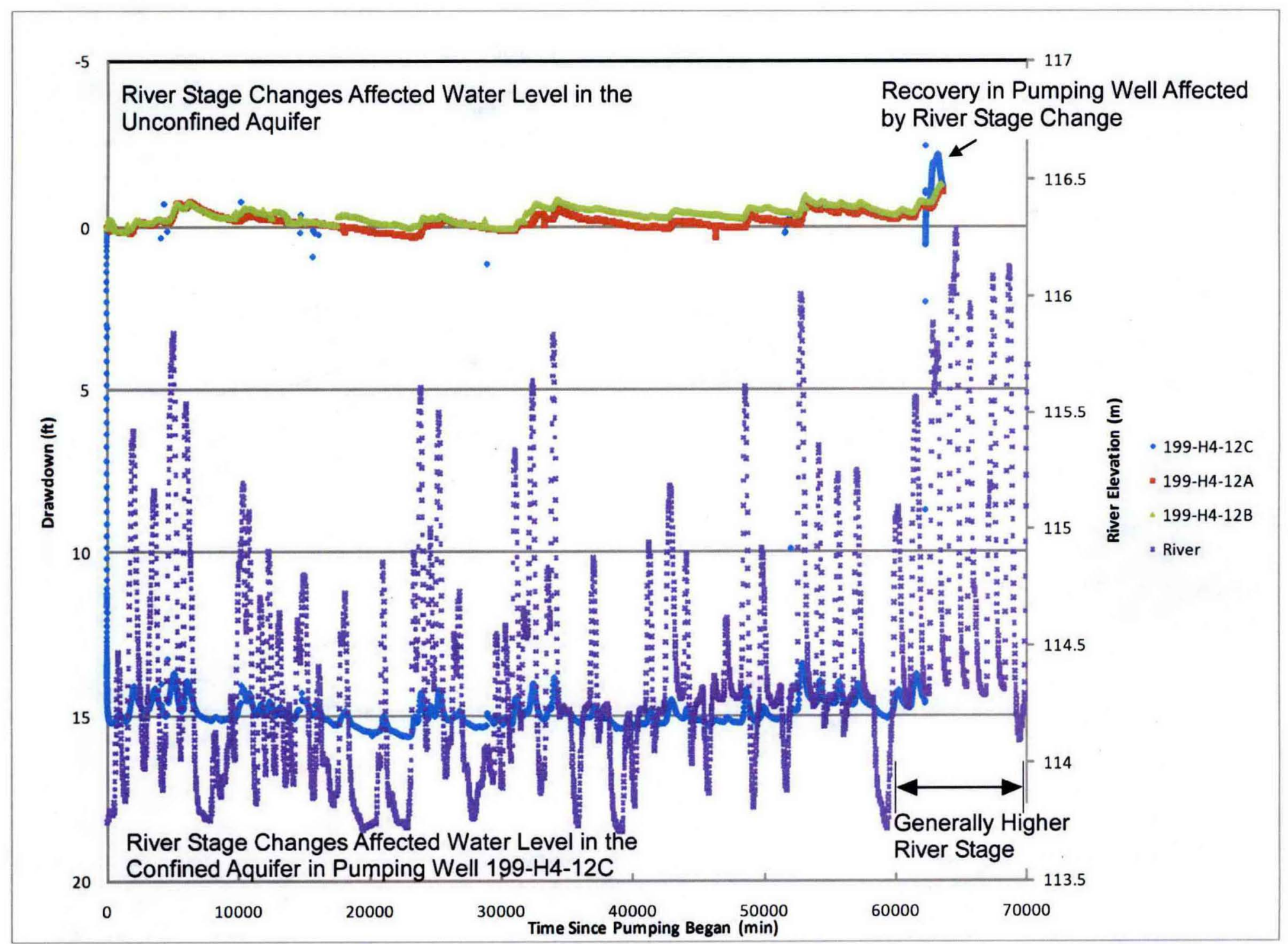

Figure 2-9. Hydrograph for Constant-Rate Pumping Test of Well 199-H4-12C 


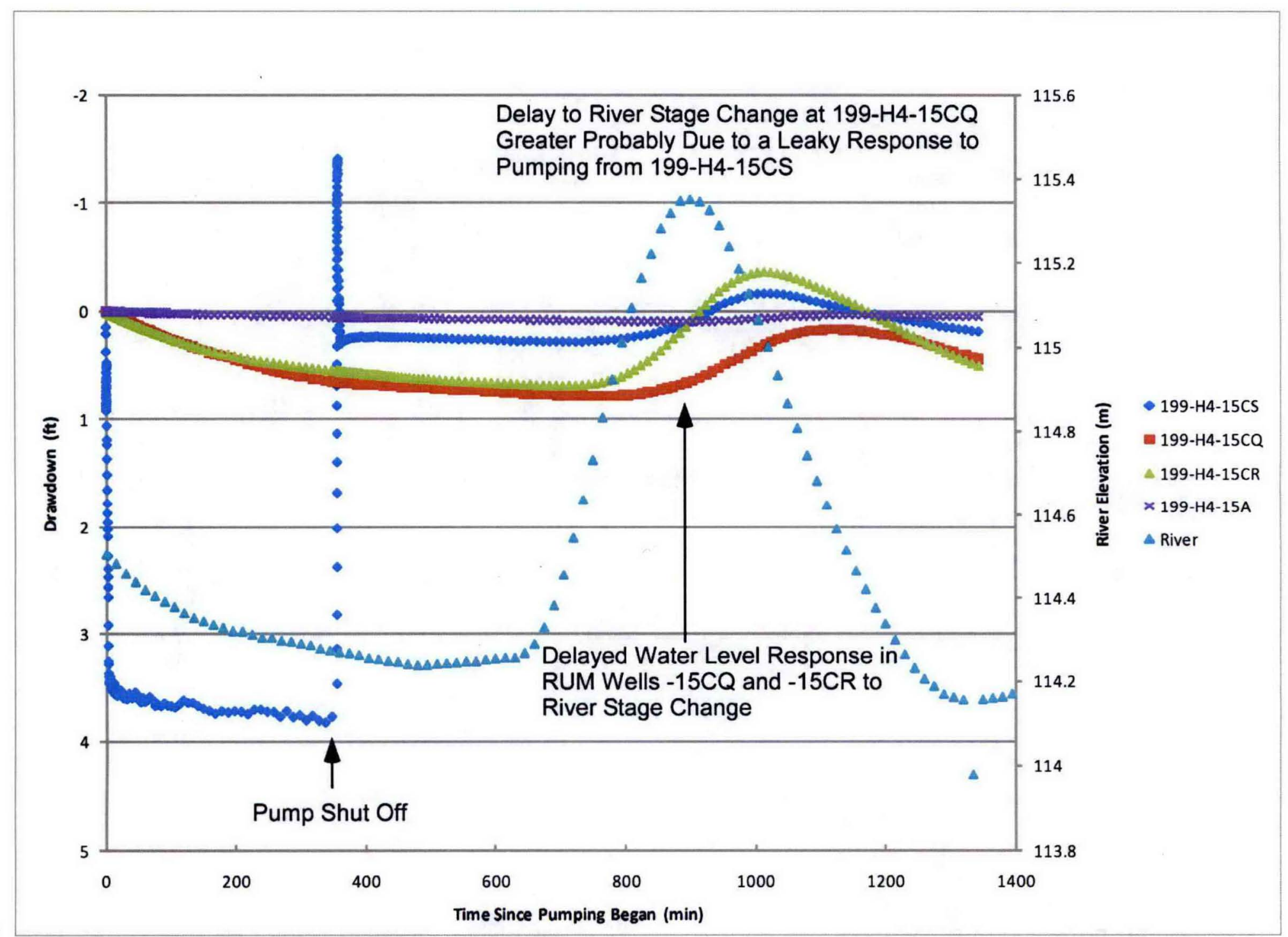

Figure 2-10. Hydrograph for Constant-Rate Pumping Test of Well 199-H4-15CS 


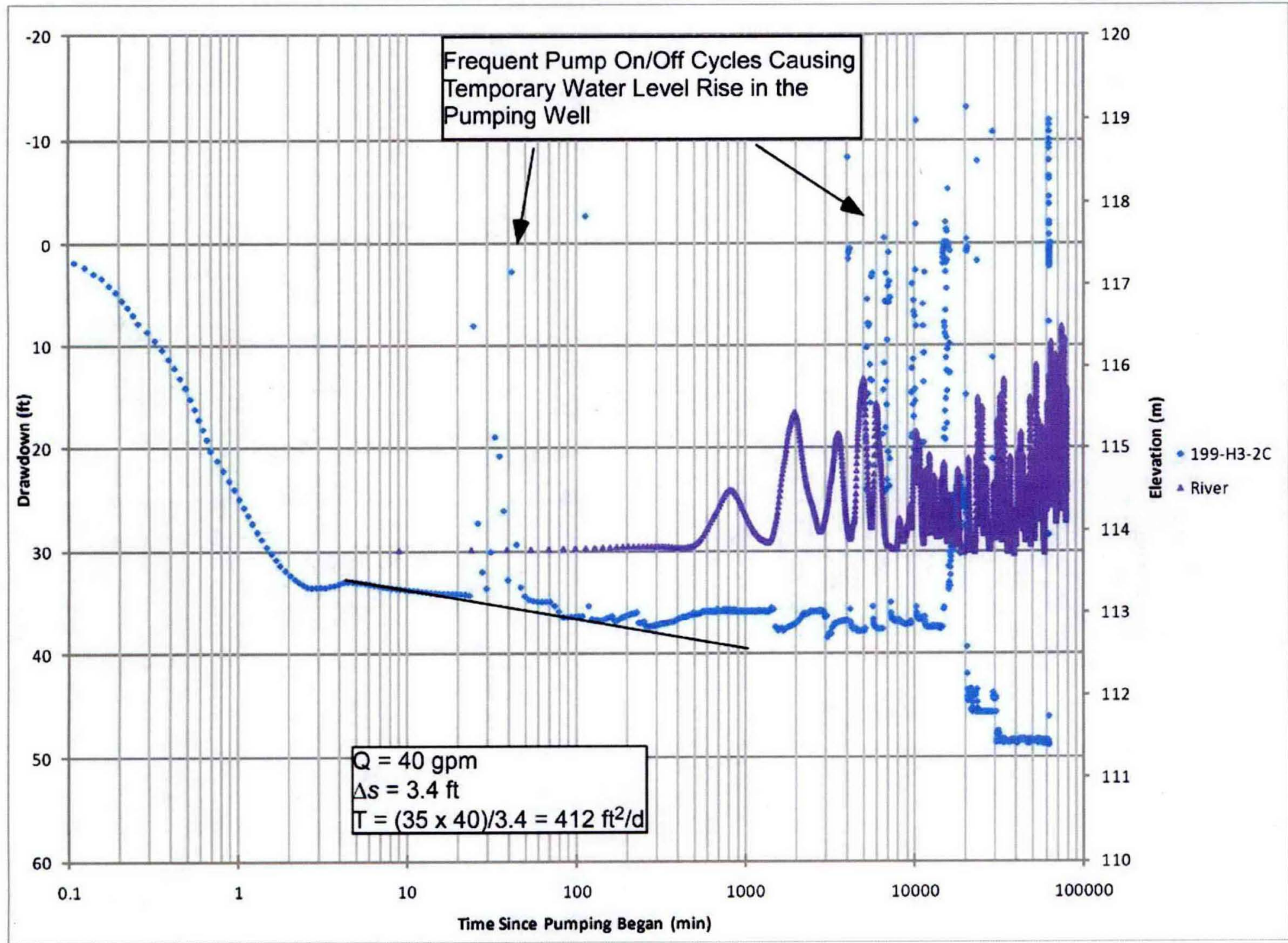

Figure 2-11. Drawdown Data for Constant-Rate Pumping Test of Well 199-H3-2C 


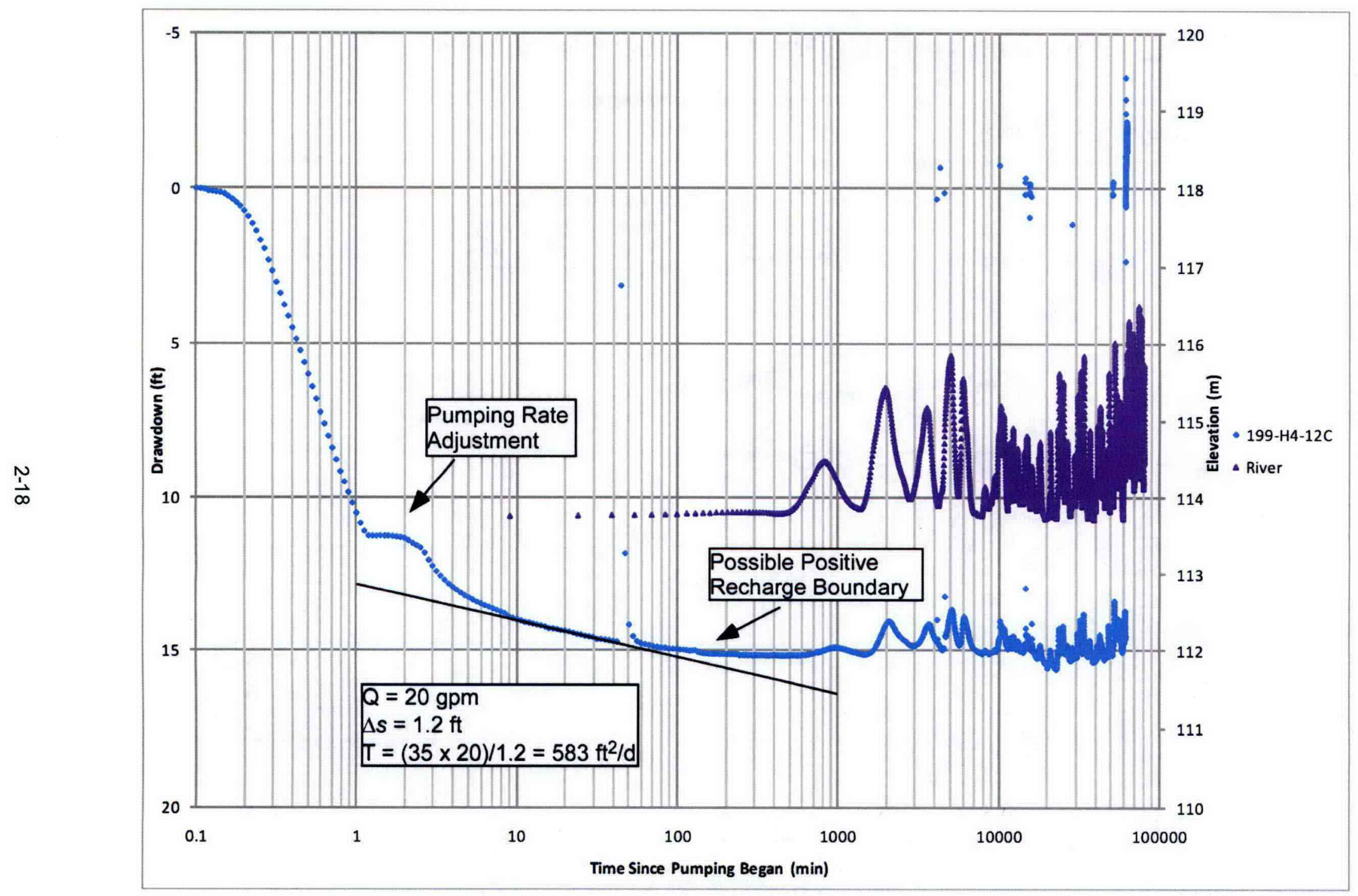

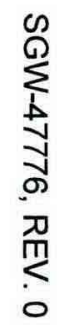

Figure 2-12. Drawdown Data for Constant-Rate Pumping Test of Well 199-H4-12C 


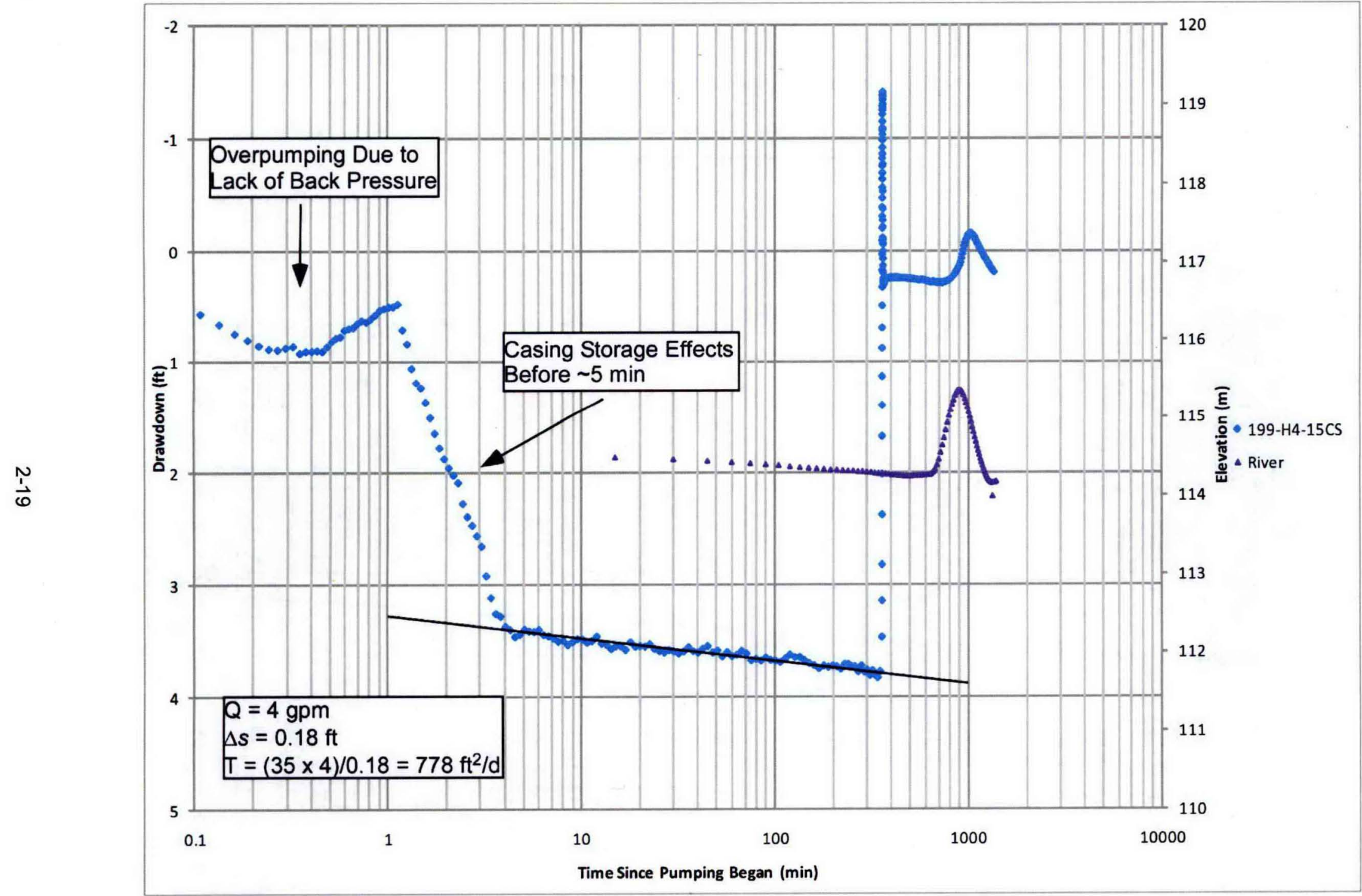

Figure 2-13. Drawdown Data for Constant-Rate Pumping Test of Well 199-H4-15CS 


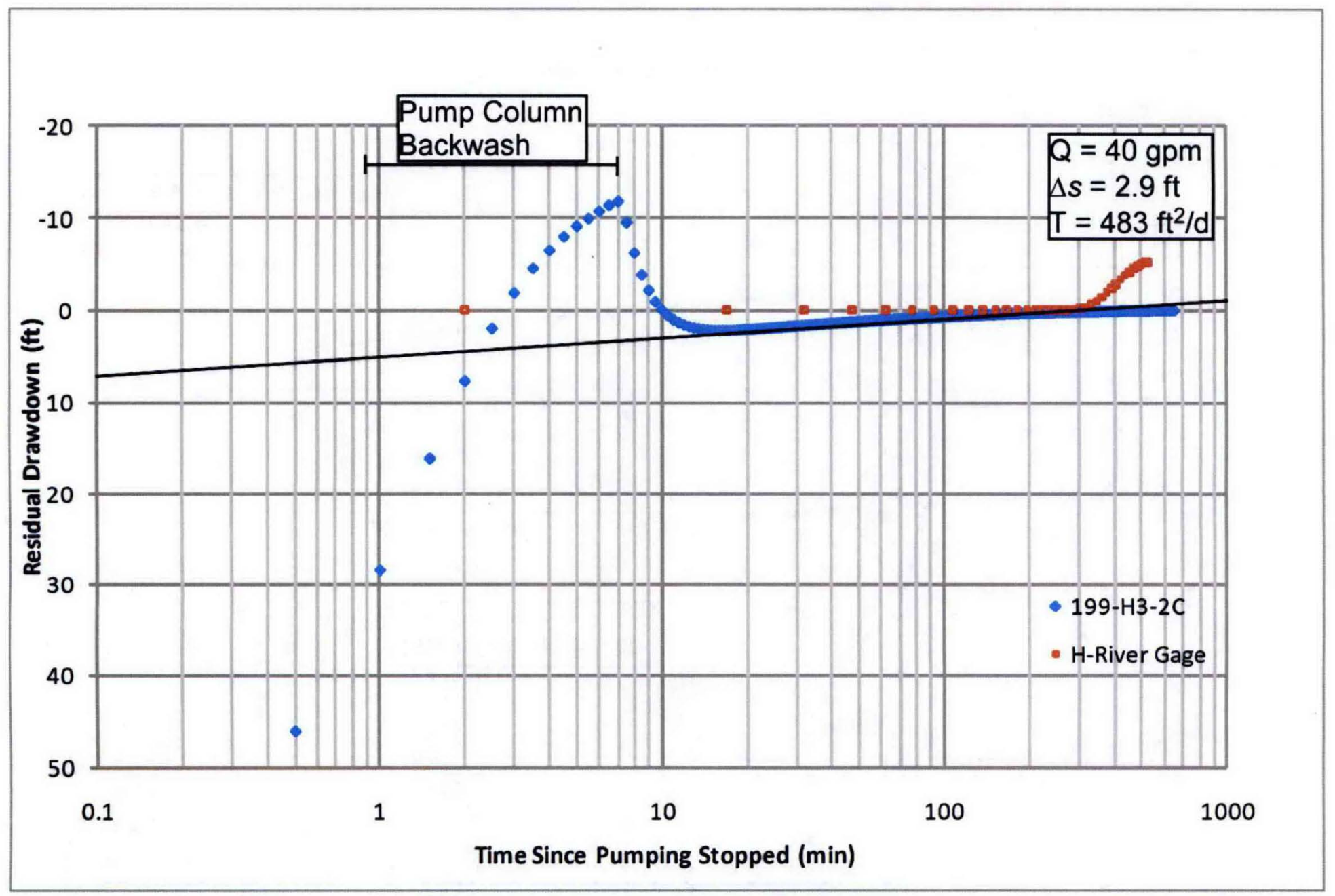

Figure 2-14. Recovery Data for Constant-Rate Pumping Test of Well 199-H3-2C 


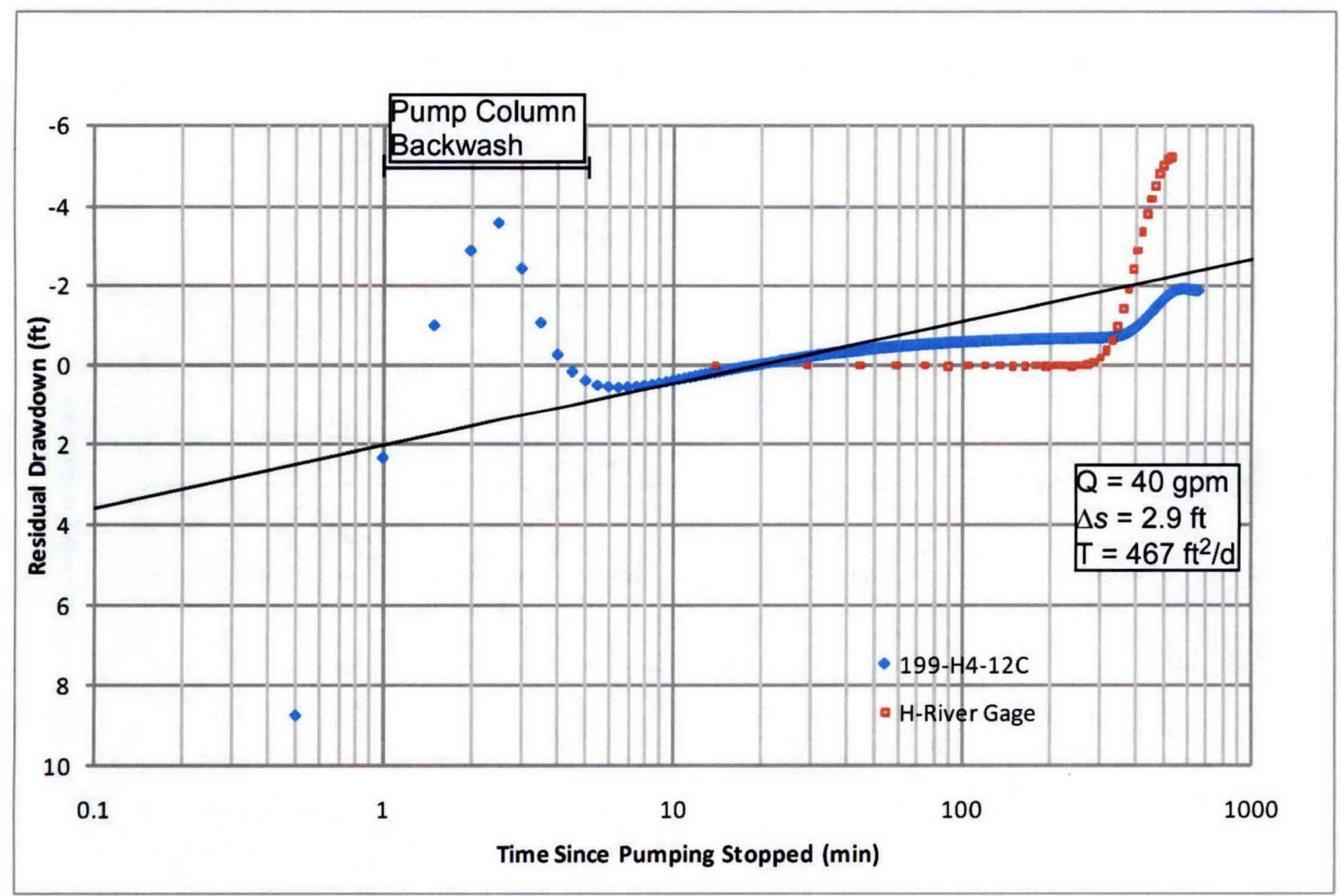

Figure 2-15. Recovery Data for Constant-Rate Pumping Test of Well 199-H4-12C 


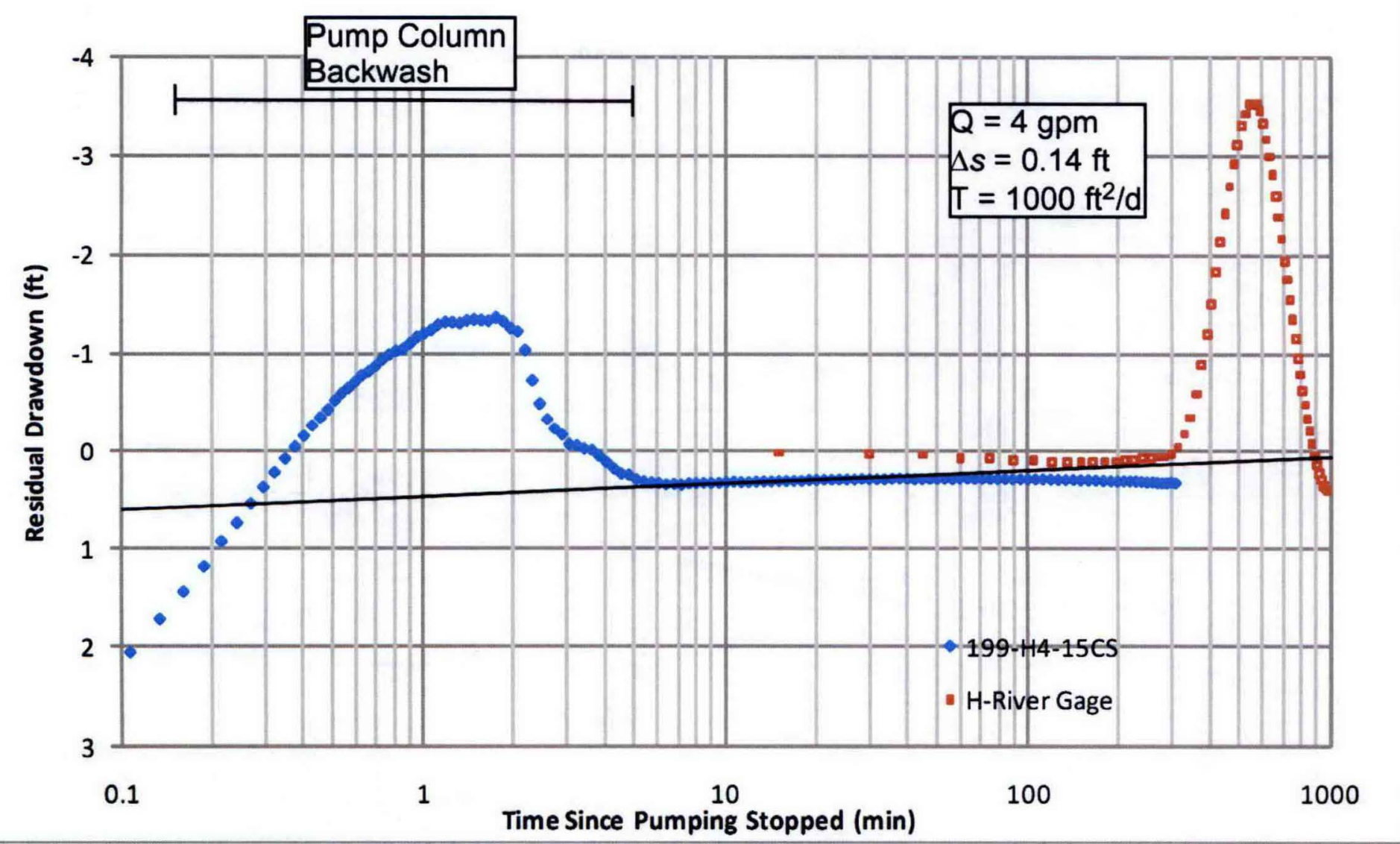

Figure 2-16. Recovery Data for Constant-Rate Pumping Test of Well 199-H4-15CS 


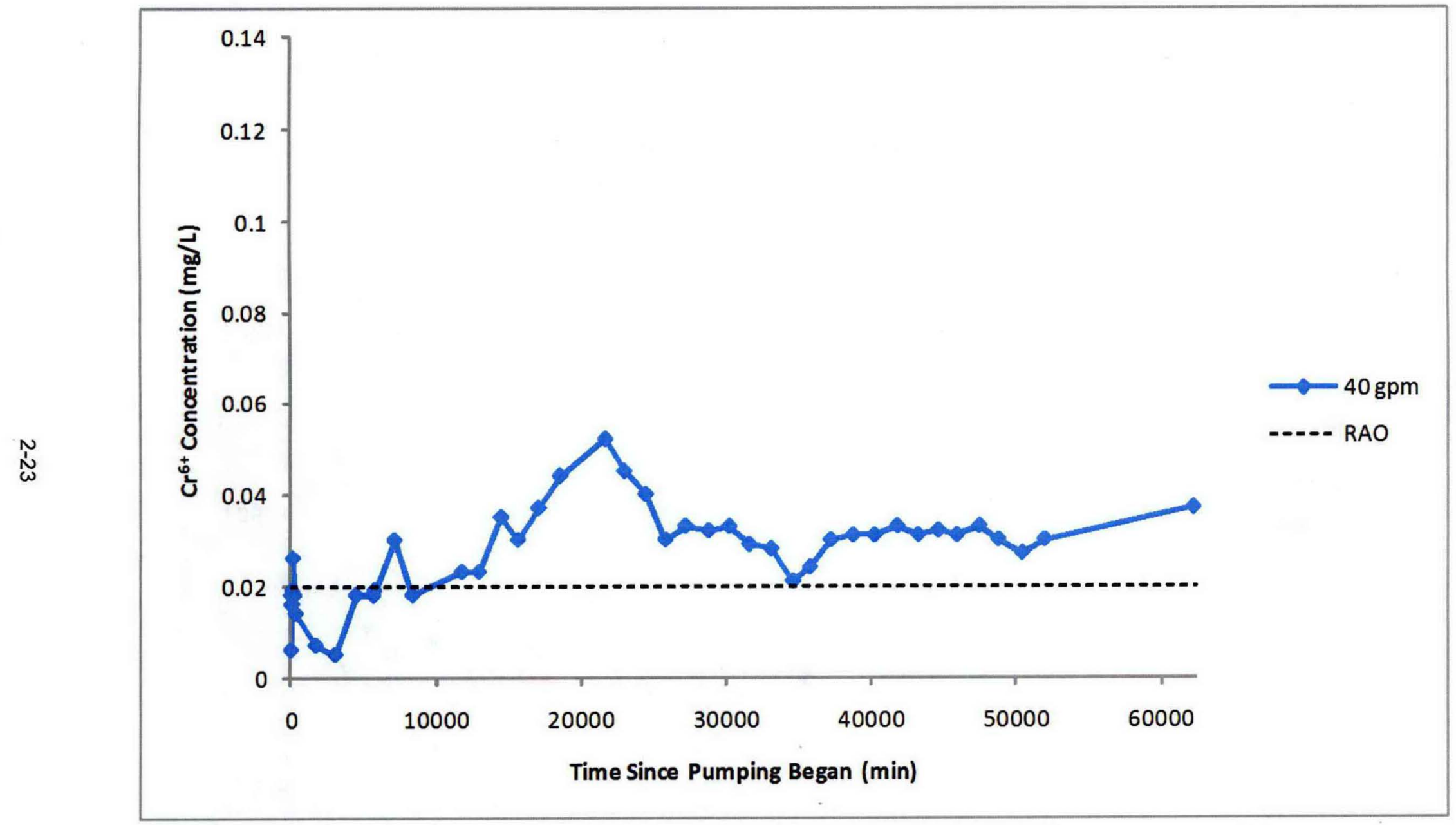

Figure 2-17. Hexavalent Chromium Sample Results for Constant-Rate Pumping Test of Well 199-H3-2C 


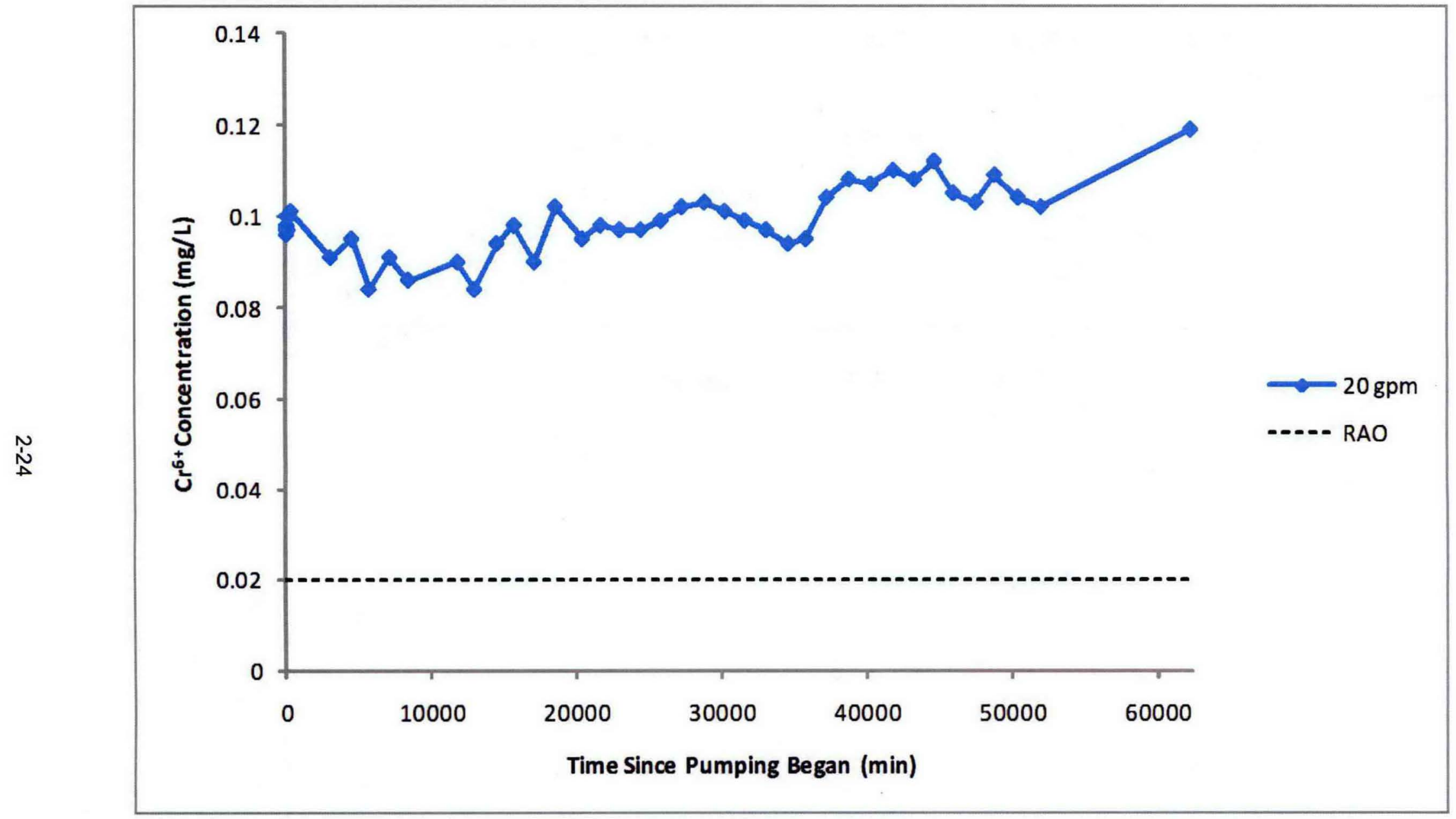

Figure 2-18. Hexavalent Chromium Sample Results for Constant-Rate Pumping Test of Well 199-H4-12C 


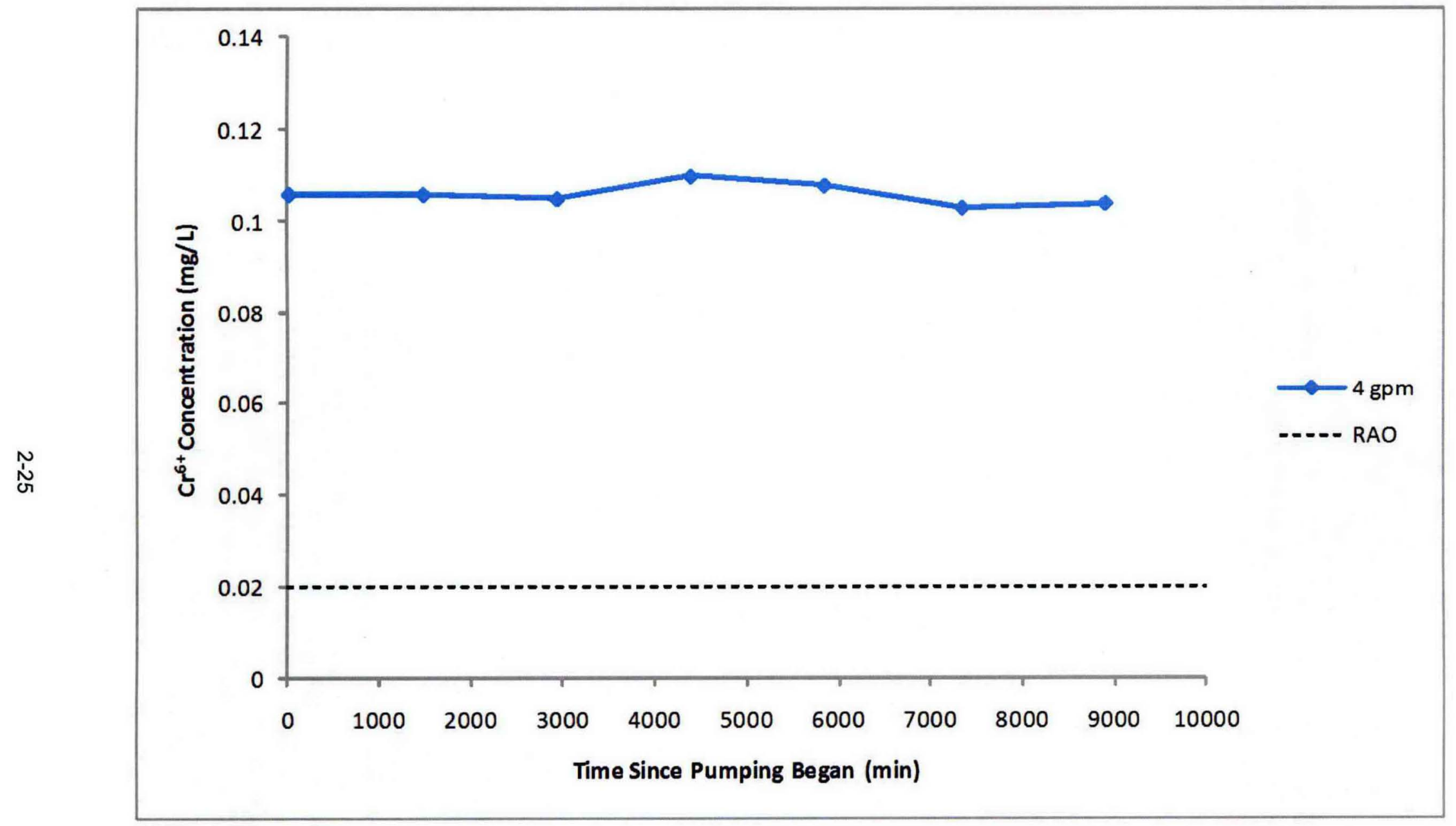

Figure 2-19. Hexavalent Chromium Sample Results for Constant-Rate Pumping Test of Well 199-H4-15CS 
The observed concentrations are consistent with the first hypothesis, given that concentrations are highest closer to the Columbia River, and that the concentrations are persistent, which suggests a large sustained source. The potential for downward intrusion along the well bore at the three locations is less likely. It is also unlikely that persistent concentrations could develop that could produce the observed steady concentrations over the duration of testing.

The lower observed concentrations at well 199-H3-2C, located inland from the higher concentration wells, suggest that the limit of chromium contamination in the RUM layer will be reached further west. This is consistent with sample measurements taken during the Horn area investigation (DOE/RL-2008-42), which showed minor amounts of hexavalent chromium contamination (less than $20 \mu \mathrm{g} / \mathrm{L}$ ) in the RUM on the west edge of the Horn area, near the 100-D Area at well 699-97-48C. The Horn area investigation attributed the contamination to a 1967 large-scale infiltration test at the 100-D Area.

\subsection{Rebound Study}

Shutdown of the 100-H Area P\&T system occurred from August 20 through November 11, 2009. This shutdown consisted of stopping all pumping of unconfined aquifer extraction wells and stopping all injection at recharge wells, except for well 199-H4-17 (Figure 2-1), which continued to receive approximately 265 to $379 \mathrm{~L} / \mathrm{min}$ ( 70 to $100 \mathrm{gal} / \mathrm{min}$ ) of treated water from the 100-D Area (and the $100-\mathrm{H}$ Area during two of the pumping tests). Wells in the shallow aquifer system of the $100-\mathrm{H}$ Area were sampled to measure the possible hexavalent chromium rebound effects of shutting off the 100-H Area P\&T system. The monitoring wells listed in Table 2-5 were sampled periodically from August 25, 2009, through March 20, 2010. Hexavalent chromium concentrations versus time for these wells are illustrated, along with river stage, in Figures 2-20 through 2-22.

Table 2-5. Rebound Study Well List

\begin{tabular}{|l|l|}
\hline \multicolumn{1}{|c|}{ Well Name } & Well Type \\
\hline 199-H4-12A, 199-H4-15A, 199-H4-3, 199-H4-4, 199-H4-63, and 199-H4-64 & Extraction \\
\hline 199-H4-14 and 199-H4-18 & Injection \\
\hline 199-H4-5, 199-H4-9, 199-H4-12B, 199-H4-13, 199-H4-15B, and 199-H4-65 & Near-field \\
\hline 199-H3-2A, 199-1-4-6, and 199-1-4-8 & Mid-field \\
\hline 199-H4-16, 199-H4-10, 199-H4-45, and 199-H4-48 & Far-field \\
\hline
\end{tabular}

The wells shown in Figures 2-20 through 2-22 were grouped by their location in regard to the three pumping wells. In general, the graphs in Figure 2-20 show no trend in hexavalent chromium concentrations during the rebound test period (August 20 through November 11, 2009), nor during the longer rebound study period (August 20 through March 25, 2010). The Columbia River stage was generally declining during most of the rebound test period. The 100-H Area P\&T system operations resumed November 11, 2009, as river stage was beginning an upward trend. Figure 2-23 shows the distribution of the wells sampled during the rebound study period and illustrates the upward and downward changes in hexavalent chromium concentration at each well sampled during the period of August 25, 2009, through March 20, 2010. This analysis was conducted to determine whether geographic trends could be recognized over the longer study period. 
Observations from the rebound study include the following:

- While the rebound study showed that most groundwater samples from monitoring wells within the 100-H Area did not have a significant change in hexavalent chromium concentrations, at least one well (far-field well 199-H4-48) did show an increase during the period when the P\&T system was shut down. From June to October 2009, hexavalent chromium concentrations increased from 5.2 to $38.6 \mu \mathrm{g} / \mathrm{L}$. However, after the average river stage increased in November 2009 and the P\&T system was restarted, the hexavalent chromium concentration in the groundwater sample from well 199-H4-48 declined sharply.

- Of the pumped wells, groundwater from only well 199-H4-12C displayed a consistent trend of increasing hexavalent chromium concentration during the constant-rate pumping test (Figure 2-18). The increase of 10 to 20 percent is not indicative of any particular source of the hexavalent chromium, and it is consistent with generally widespread occurrence of trace hexavalent chromium in the confined RUM aquifer zones in the vicinity of the 100-H Area.

- Inspection of hexavalent chromium concentration versus time (Figures 2-20 through 2-22) does not indicate clear concentration trends for hexavalent chromium in unconfined aquifer monitoring wells subsequent to temporary shutdown of the 100-H Area P\&T system. 


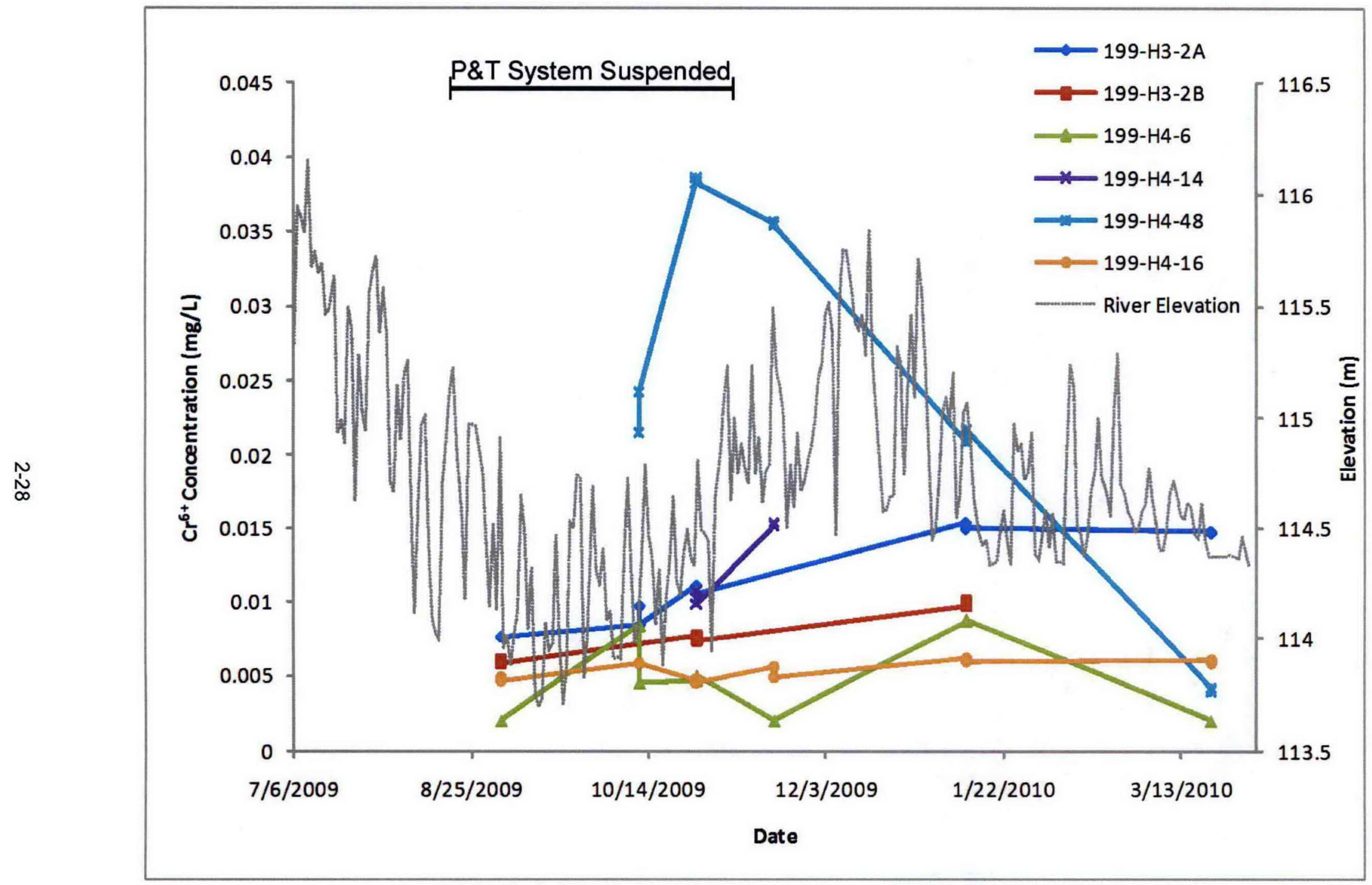

Figure 2-20. Rebound Study Hexavalent Chromium Concentrations Near Well 199-H3-2C 


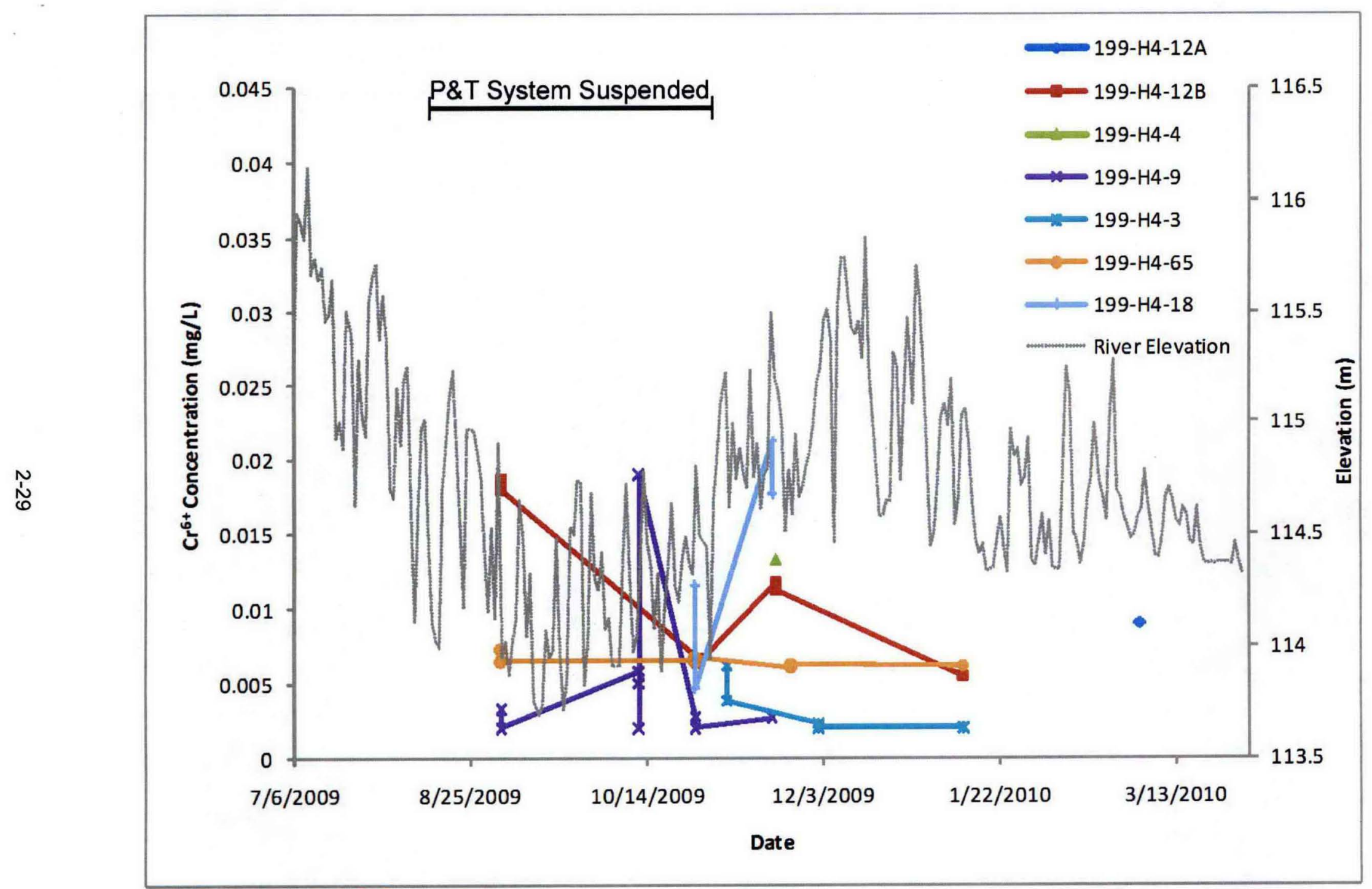

Figure 2-21. Rebound Study Hexavalent Chromium Concentrations Near Well 199-H4-12C 


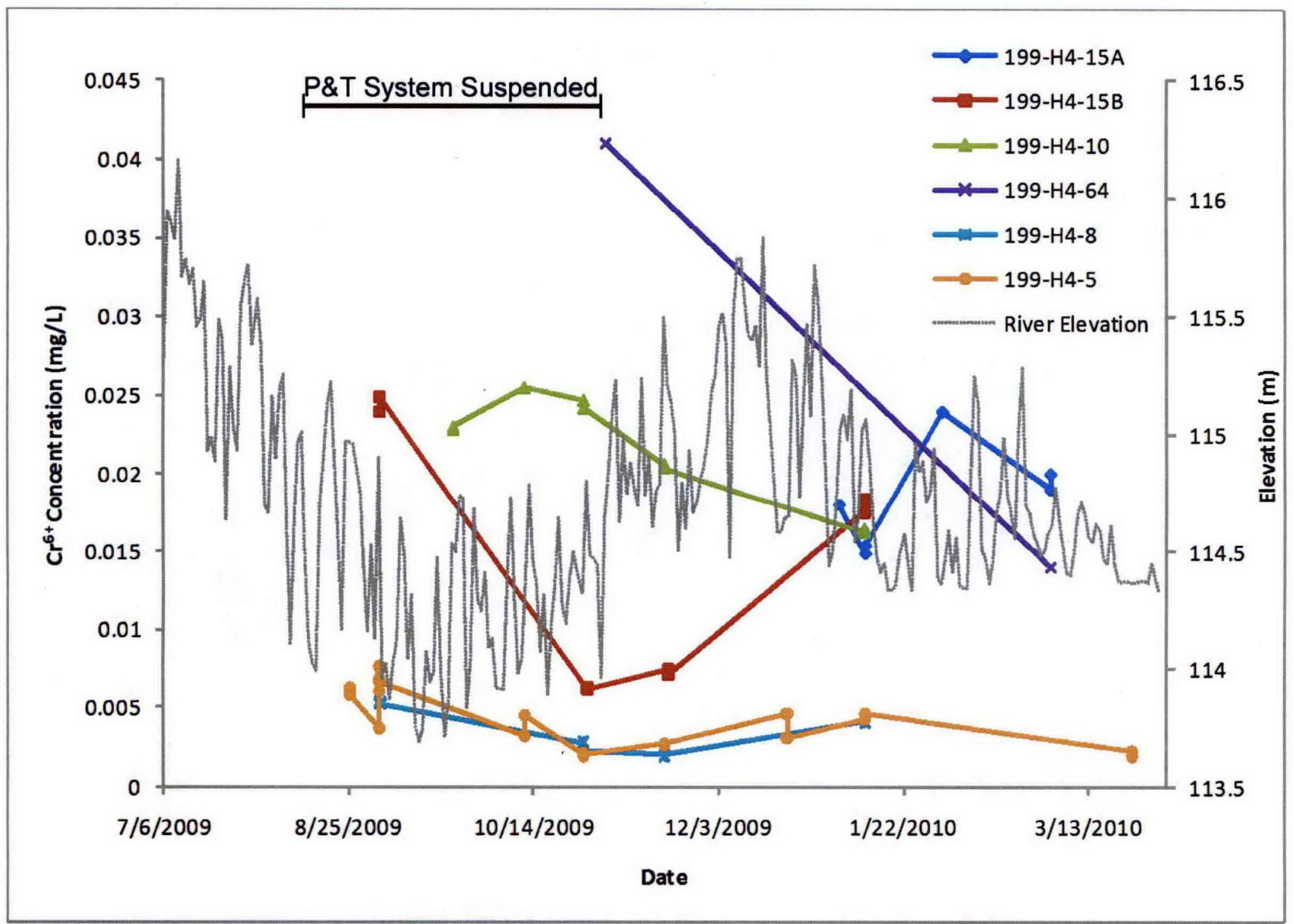

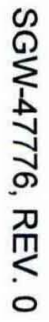

Figure 2-22. Rebound Study Hexavalent Chromium Concentrations Near Well 199-H4-15CS 


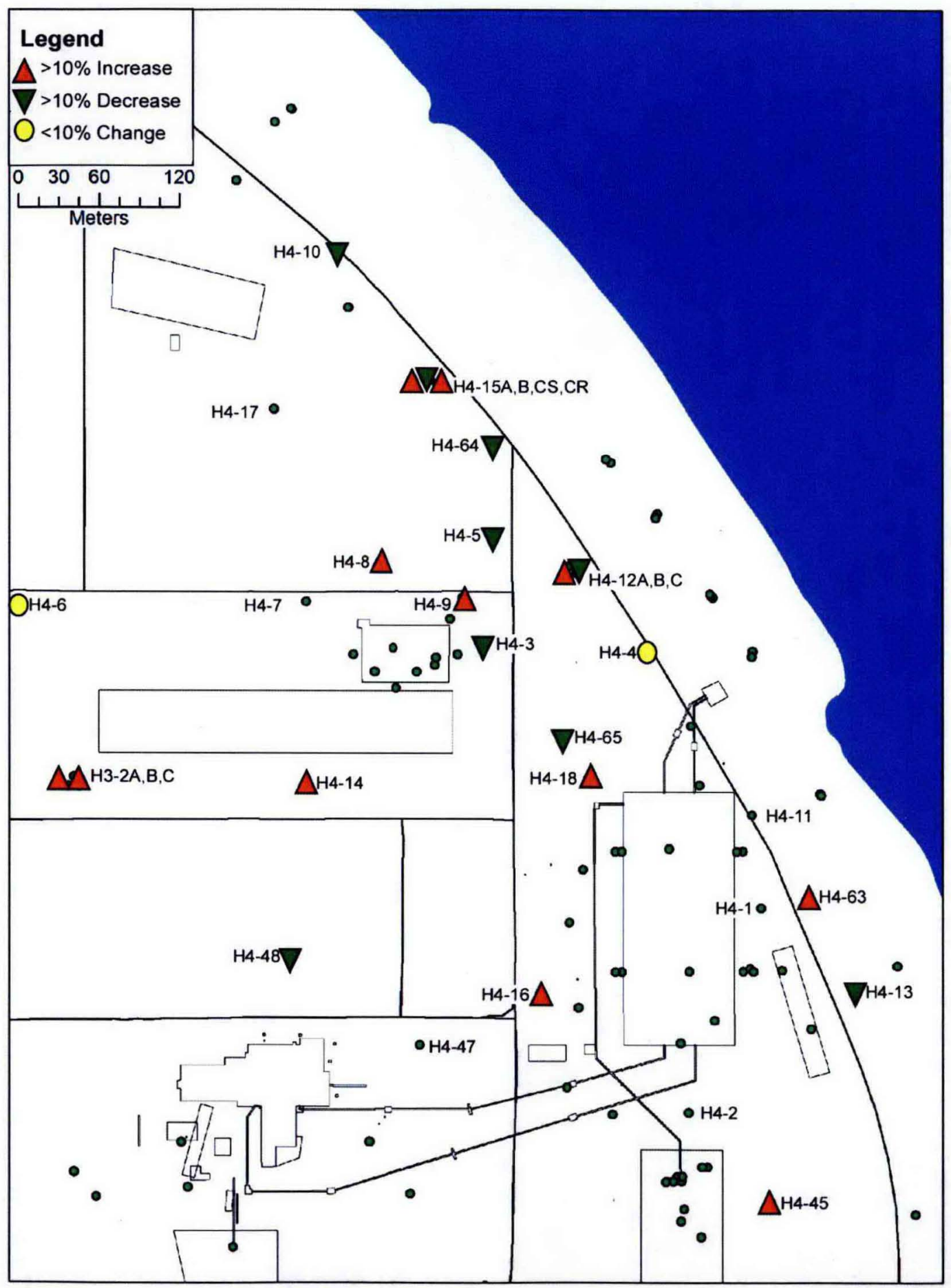

Figure 2-23. Change in Hexavalent Chromium Concentration in 100-H Area Wells, August 25, 2009, Through March 24, 2010 
SGW-47776, REV. 0 


\section{Test Analysis}

This chapter provides an analysis of the data sets described in Chapter 2, including the following:

- Pre-test water levels for wells and Columbia River stage

- Step-drawdown tests for three confined aquifer wells

- Constant-rate pumping tests for three confined aquifer wells

- Rebound test analysis for unconfined and confined aquifer wells.

\subsection{Analysis of the Pre-Test Water-Level Data}

To understand the effects of Columbia River stage on groundwater levels at different wells, a total of 16 pre-test hydrographs were analyzed, representing 16 different wells. The pre-test hydrographs showed water-level transducer data gathered during the period of July 1 through mid-September 2009, which clearly illustrate the effect of river stage on water level in all of the wells. Some of the hydrographs show detectable hydraulic effect of groundwater withdrawal at nearby P\&T wells. For example, Figure 3-1 shows that the water level in well 199-H4-12A increased approximately $0.15 \mathrm{~m}(0.5 \mathrm{ft})$ on August 14 and again on August 18 in response to possible pump shutoff at nearby $100-\mathrm{H}$ Area extraction well 199-H4-12B.

Three ways that river stage may affect groundwater levels include the following:

- Hydraulic connection through permeable sediments (buried channel)

- Hydraulic connection through a leaky aquitard

- Loading on a compressible aquitard.

With a direct hydraulic connection (including a connection through a leaky aquitard), a response delay to changes in Columbia River change would be expected, whereas with a loading effect on a compressible aquitard, the hydraulic response should be almost immediate. Table 3-1 presents the ratio of groundwaterlevel response to changes in Columbia River stage. Table 3-1 also summarizes the time delay for groundwater-level response after peak river stage, calculated from the pre-test data.

Impact from the injection of treated water from 100-D Area extraction wells to the unconfined aquifer via well 199-H4-17 was estimated for the test. This well is approximately $320 \mathrm{~m}(1,050 \mathrm{ft})$ from the test wells with injection rates less than $265 \mathrm{~L} / \mathrm{min}(70 \mathrm{gal} / \mathrm{min})$. The injection was not estimated to cause significant water-level mounding effects in the unconfined aquifer at the pumping test locations. Calculations to estimate the radius of influence and the magnitude of water-level changes due to injection showed that little to no water-level change would occur at distances of approximately $320 \mathrm{~m}(1,050 \mathrm{ft})$ from the injection well. However, the ability to make precise calculations to estimate the vertical hydraulic conductivity of the upper RUM between the pumped layer and the unconfined aquifer potentially could be impacted. 


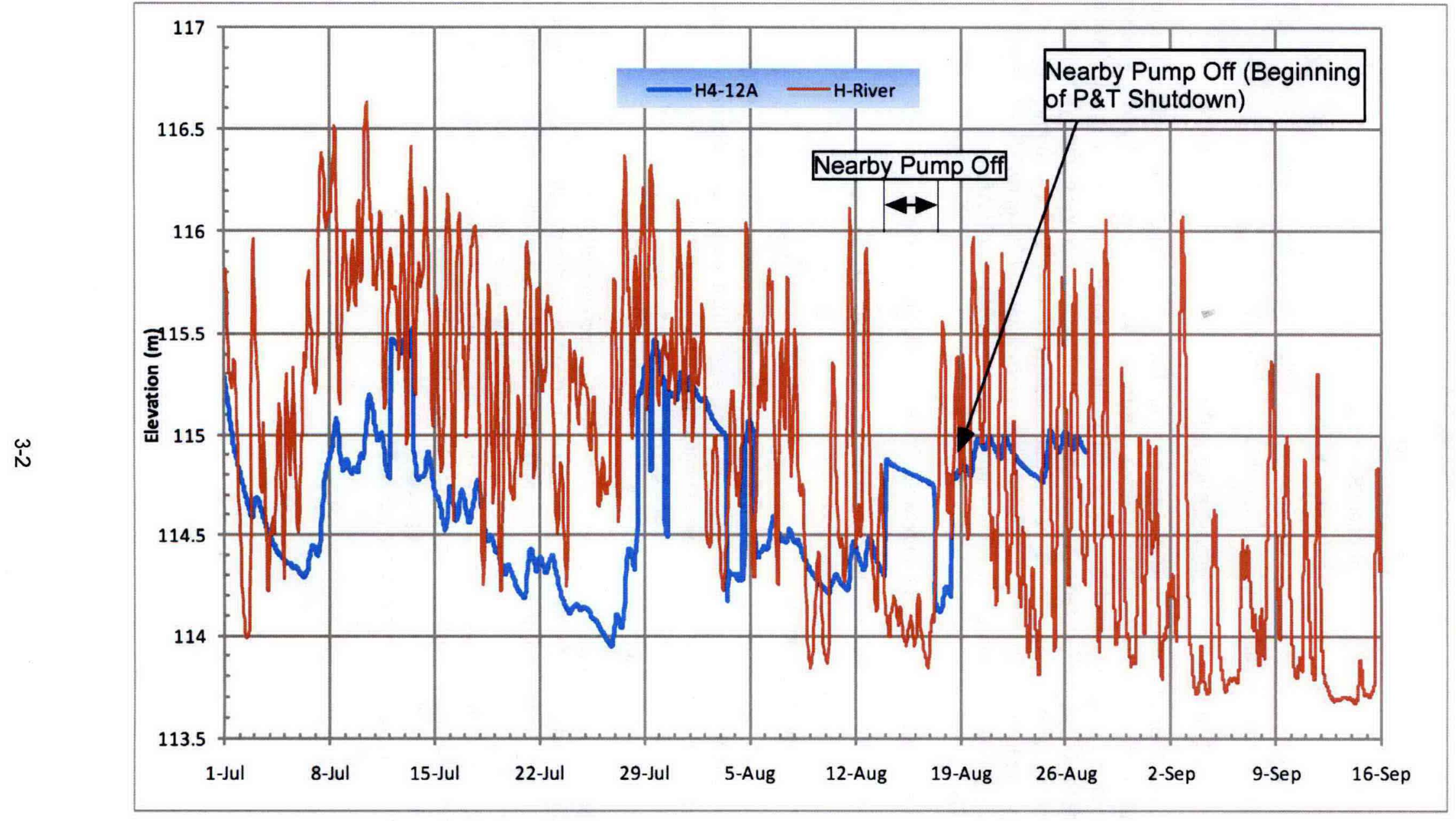

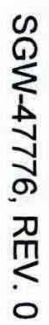

Figure 3-1. Pre-Test Hydrograph of Well 199-H4-12A and the Columbia River 
Table 3-1. Summary of Water-Level Response to Pre-Test River Stage Changes

\begin{tabular}{|c|c|c|c|}
\hline $\begin{array}{c}\text { Well } \\
\text { Name }\end{array}$ & $\begin{array}{c}\text { Distance to } \\
\text { Columbia River } \\
\text { Shoreline } \\
\text { (ft) }\end{array}$ & $\begin{array}{c}\text { Ratio of Well } \\
\text { Response (River } \\
\text { Stage Change) }\end{array}$ & $\begin{array}{c}\text { Water-Level Delay to } \\
\text { Columbia River Stage } \\
\text { Change (hours) }\end{array}$ \\
\hline $199-\mathrm{H} 3-2 \mathrm{C}$ & 1,820 & 0.08 & 13 \\
\hline $199-\mathrm{H} 4-12 \mathrm{C}$ & 440 & 0.30 & Immediate to less than 0.5 \\
\hline $199-\mathrm{H} 4-15 \mathrm{CS}$ & 470 & 0.26 & 3 \\
\hline
\end{tabular}

\subsection{Analysis of the Step-Drawdown Test Data}

Step-drawdown test data were analyzed to determine if well losses increased significantly at higher pumping rates. Typically, if entrance velocities are maintained below $0.03 \mathrm{~m} / \mathrm{sec}(0.1 \mathrm{ft} / \mathrm{sec})$ laminar flow of groundwater through the well screen, the well efficiency will be near 100 percent, provided that the well is properly developed (Groundwater and Wells [Driscol, 1986]). Given the well diameters and screen-slot configurations of the pumping wells, entrance velocities should not exceed $0.03 \mathrm{~m} / \mathrm{sec}$ $(0.1 \mathrm{ft} / \mathrm{sec})$ at even the highest pumping rates used during the tests. Specific capacities did not change significantly (or at all) during the step-drawdown tests; thus, well losses were expected to be negligible. Open area at well 199-H4-15CS is limited by small screen diameter (5.1 cm [2-in.]) and small screen

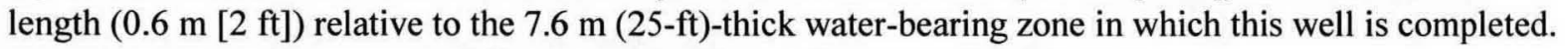
The other two wells appear to fully screen their respective water-bearing zones.

The concentration of hexavalent chromium in pumped water during step-drawdown testing (Figures 2-5 through 2-7) was generally stable in each well throughout the tests. Small temporary spikes in apparent chromium concentration seen immediately after pumping rate increases in wells 199-H3-2C and 199-H4-12C may be related to increased turbidity caused by effectively surging the well.

\subsection{Analysis of the Constant-Rate Pumping Test Data}

The effects of changes in river stage, positive recharge boundaries (i.e., injection well 199-H4-17), and slight variations in the discharge rate created challenges for estimating aquifer transmissivity. The storage coefficient could not be determined from the pumping test data because the observation wells are not completed in the same aquifer as the pumping wells. However, the close vertical proximity of observation well screens in water-bearing zones, relative to the pumped water-bearing zone, could be useful for qualitative interpretation of hydrologic properties of the RUM.

Empirical methods can be used to estimate aquifer transmissivity from specific capacity data; however, these methods do not allow for the effects of positive recharge boundaries. Interception of such boundaries during constant-rate pumping tests was likely due to the proximity of the Columbia River, especially at well 199-H4-12C. The steep upward vertical gradient demonstrated by the nested piezometers at well 199-H4-15C would be expected to cause an apparent positive recharge boundary if the underlying aquitard was leaking. Columbia River stage fluctuated many times throughout the 42-day testing period, and a general increase in average Columbia River stage elevation of approximately 0.3 to $0.6 \mathrm{~m}$ ( 1 to $2 \mathrm{ft})$ was observed. 
The unconfined aquifer monitored by wells $199-\mathrm{H} 3-2 \mathrm{~A}$ and $199-\mathrm{H} 3-2 \mathrm{~B}$ was affected by pumping from a water-bearing zone in the RUM at well 199-H3-2C (Figure 2-8). Total drawdown in these two wells, located 7.5 and $7.8 \mathrm{~m}(24.5$ and $25.7 \mathrm{ft})$ from the pumping well, was $0.2 \mathrm{~m}(0.7 \mathrm{ft})$ during the test period. When the pump in well 199-H4-12C was shut off, the water level in the two observation wells began to recover, confirming that the water-level decline at these two wells was due to drawdown caused by the pumping well. Closer to the Columbia River, the water-level elevation in the unconfined aquifer monitored by wells 199-H4-12A and 199-H4-12B increased during the pumping test of well 199-H4-12C, showing the effect of generally rising river stage on these observation wells. The water level in observation wells monitoring the unconfined aquifer near well 199-H4-12C did not react to the pump shutoff but instead continued to follow the changing river stage.

The water-level response at wells 199-H3-2A and 199-H3-2B (Figure 2-8) suggests a hydraulic connection between the water-bearing zone in the RUM pumped by well 199-H3-2C and the unconfined aquifer. It is difficult to determine from pumping test data whether the hydraulic connection is through a leaky aquitard or due to poor sealing of the well 199-H3-2C borehole; however, the steady drop in water level in the unconfined aquifer suggests that this is not a borehole issue but rather an issue of leakage between zones. The geologic descriptions in the borehole log suggest that the RUM layers at well 199-H3-2C, which overlie the well screen, are more permeable than the geologic materials adjacent to the screen. The completion information in borehole log for well 199-H3-2C shows the existence of a bentonite seal above the well screen. The positive recharge boundary seen in the drawdown data (Figure 2-11) at approximately 250 minutes was likely due to the expanding cone of drawdown within the pumped water-bearing zone encountering leakage from the unconfined aquifer.

An analysis of the drawdown and recovery data was conducted using the Cooper-Jacob straight-line method ("A Generalized Graphical Method for Evaluating Formation Constants and Summarizing Well Field History" [Cooper and Jacob, 1946]). This single-well analysis method was chosen due to the confined nature of each water-bearing zone tested and the lack of suitable same-aquifer observation wells. The Cooper-Jacob straight-line method was applied to the drawdown results in Figures 2-11 through 2-13 and the recovery results in Figures 2-14 through 2-16. The calculations are marked on the graphs in these figures and are summarized in Table 3-2.

Table 3-2. Estimates of Aquifer Transmissivity

\begin{tabular}{|c|c|c|c|}
\hline Analysis Method & $\begin{array}{c}\text { 199-H3-2C } \\
\left(\mathrm{ft}^{2} / \mathrm{day}\right)\end{array}$ & $\begin{array}{c}199-\mathrm{H} 4-12 \mathrm{C} \\
\left(\mathrm{ft}^{2} / \mathrm{day}\right)\end{array}$ & $\begin{array}{c}\text { 199-H4-15CS } \\
\left(\mathrm{ft}^{2} / \mathrm{day}\right)\end{array}$ \\
\hline Cooper-Jacob $^{a}$ method using drawdown data ${ }^{b}$ & 412 & 583 & 778 \\
\hline Cooper-Jacob $^{\mathrm{a}}$ method using recovery data & 483 & 467 & 1,000 \\
\hline Empirical - Driscol ${ }^{\mathrm{c}}$ from specific capacity data & 220 & 342 & 281 \\
\hline
\end{tabular}

a. "A Generalized Graphical Method for Evaluating Formation Constants and Summarizing Well Field History" (Cooper and Jacob, 1946).

b. Transmissivity values estimated from the semi-log plots of drawdown data are considered best estimates in this document.

c. Groundwater and Wells (Driscol, 1986). 
During each test, the first 4 to 6 minutes of drawdown data from each pumping well are affected by casing storage effects. This is most clearly illustrated in Figure 2-13, where a sharp change in drawdown slope for pumping well 199-H4-15CS is encountered at approximately 6 minutes. The sand pack in this $27.9 \mathrm{~cm}$ (11-in.)-diameter borehole extends from 22.9 to $25.3 \mathrm{~m}$ (75 to $83 \mathrm{ft}$ ) below ground surface (bgs), which likely has different hydraulic properties than the surrounding natural formation, thereby potentially creating a more pronounced casing storage effect than would normally be expected. Therefore, drawdown data were analyzed after casing storage effects were negligible, and prior to when it appeared that a positive recharge boundary was encountered. Recovery data were analyzed after the effects of pump column backwash. A positive recharge boundary was encountered after approximately 110 minutes at well 199-H4-12C (Figure 2-12) and after approximately 300 minutes at well 199-H3-2C (Figure 2-11).

For comparison purposes, an empirical method (the Driscoll method, based on Estimating the Transmissivity of a Water Table Aquifer from the Specific Capacity of a Well [Theis, 1963]) was used to derive transmissivity estimates directly from long-term specific capacity data (Table 3-2); however, in this document, the transmissivity values derived using the Cooper-Jacob straight-line method (applied to the drawdown data) are considered to be the most valid estimate. Application of the Cooper-Jacob method to drawdown and recovery data provided similar transmissivity results for pumping wells 199-H3-2C and 199-H4-12C, with slight differences (about 10 percent) likely attributed to river stage effects. The recovery plot of well 199-H4-15CS was more strongly influenced by slightly declining river stage and, therefore, generated an exaggerated estimate of transmissivity $\left(92.9 \mathrm{~m}^{2} /\right.$ day $\left[1,000 \mathrm{ft}^{2} /\right.$ day $]$ ). The estimate of transmissivity obtained from the drawdown data for well 199-H4-15CS is considered the better estimate $\left(72.3 \mathrm{~m}^{2} /\right.$ day $\left[778 \mathrm{ft}^{2} /\right.$ day $\left.]\right)$.

The transmissivity values obtained using the Cooper-Jacob drawdown method were approximately 1.7 to 2.8 times greater than the transmissivity estimates obtained directly from specific capacity data using the empirical method, which is based on specific capacity of each well.

Partial penetration of the water-bearing zones within the RUM, especially in the case of well 199-H4-15CS, can explain why observed specific capacity was low relative to the transmissivity estimated using the Cooper-Jacob method. The borehole log for the four nested well completion at well 199-H4-15 describes numerous thin, fine-grained, possible water-bearing zones within the RUM between the screened depth interval of well 199-H4-15CS and the underlying basalt surface (Appendix A). The upward vertical gradient illustrated by the water levels in the nested observation wells (e.g., the basalt piezometer shows flowing artesian conditions) may explain both the apparent positive boundary effects as well as the higher-than-expected transmissivity given the relatively low specific capacity.

As previously noted, borehole $199-\mathrm{H} 4-15 \mathrm{C}$ contains four nested, $5.1 \mathrm{~cm}$ (2-in.)-diameter piezometers, each completed within separate, confined, water-bearing zones within and beneath the RUM. The bottom piezometer (199-H4-15CP) is screened within the basalt aquifer and contains flowing artesian water pressure (Table 2-4). This piezometer was not monitored during testing due to the flowing condition. Prior to the pumping test, the static groundwater levels demonstrated a fairly steep upward vertical gradient within the borehole (Table 2-4 and Appendix A).

Figure 2-10 shows groundwater levels declining at the beginning of testing due to declining river stage. A hydraulic connection between different water-bearing zones within the RUM is possible; however, direct vertical leakage within borehole $199-\mathrm{H} 4-15 \mathrm{C}$ was not evident from testing. Instead, it appears that a leaky aquitard exists between the aquifer zone monitored by well screen ( 23.8 to $24.4 \mathrm{~m}$ [78 to $80 \mathrm{ft}$ bgs) of the pumping well (199-H4-15CS) and the lower aquifer zone monitored by piezometer 199-H4-15CR (screened 59.1 to $59.7 \mathrm{~m}$ [194 to $196 \mathrm{ft}$ ] bgs). Figure 2-10 clearly shows that the water 
level in well 199-H4-15CR did not respond to pump shut off at well 199-H4-15CS for at least 400 minutes. If the well borehole were poorly sealed, a more immediate response would have occurred at well 199-H4-15CR following pump shutoff. There appears to be a delayed response to pumping wells 199-H4-15CS at 199-H4-15CR, which can be explained by leakage through the aquitard between the pumped water-bearing zone and the zone monitored by well 199-H4-15CR. This interpretation is based on the delayed response at well 199-H4-15CR relative to the response at wells 199-H4-15CS or 199-H4-15CQ. Similar groundwater-level elevations and similar groundwater-level response at wells 199-H4-15CS and 199-H4-15CR to river stage changes in Figure 2-10 suggest that these two RUM water-bearing zones are distinct from the zone monitored by the deeper piezometer 199-H4-15CQ and the unconfined zone monitored by well 199-H4-15A.

No discernable response was observed in the unconfined aquifer during testing, which is likely is due to masking of the drawdown due to river stage changes and contribution from injection at well 199-H4-17. The potential exists for more robust testing with less interference after the DX P\&T system comes online and injection can be completely shut off in the 100-H Area prior to start up of the HX P\&T system.

\subsection{Comparison to Previous Testing Results}

Previous testing and estimation of aquifer transmissivity and hydraulic conductivity were performed at two of the three wells (PNL-6448, Ground-Water Monitoring Compliance Projects for Hanford Site Facilities, Progress Report for the Period April 1 to June 30, 1987). Table 3-3 lists information summarized in PNL-6468 for these wells.

Table 3-3. Summary of Hydrologic Testing Performed in 1987

\begin{tabular}{|l|c|c|c|c|c|c|}
\hline $\begin{array}{c}\text { Well } \\
\text { Name }\end{array}$ & $\begin{array}{c}\text { Screened } \\
\text { Interval } \\
\text { (ft bgs) }\end{array}$ & Formation & $\begin{array}{c}\text { Height } \\
\text { Water } \\
\text { Column }\end{array}$ & $\begin{array}{c}\text { Transmissivity } \\
\text { (ft }{ }^{2} / \text { day) }\end{array}$ & $\begin{array}{c}\text { Hydraulic } \\
\text { Conductivity } \\
\text { (ft/day) }\end{array}$ & $\begin{array}{c}\text { Date } \\
\text { Tested }\end{array}$ \\
\hline 199-H3-2C & 100 to 110 & Ringold & 70 & 600 & 60 & $4 / 23 / 1987$ \\
\hline 199-H4-12C & 72 to 82 & Ringold & 46 & 1,400 & 140 & $4 / 28 / 1987$ \\
\hline 199-H4-15(S) & 78 to 80 & Ringold & 50 & -- & -- & - \\
\hline
\end{tabular}

Notes: Data in this table are from PNL-6468, Ground-Water Monitoring Compliance Projects for Hanford Site Facilities, Progress Report for the Period April 1 to June 30, 1987.

Only a summary of the two tests was included in PNL-6468, and it was not clear if the results were included in any other published document. The information in Table 3-3 suggests that separate pumping tests were performed at wells 199-H3-2C and 199-H4-12C in April 1987; transmissivity was estimated from the drawdown data, and hydraulic conductivity was estimated by dividing the transmissivity value by the length of the screened interval. The 1987 transmissivity values listed for wells $199-\mathrm{H} 3-2 \mathrm{C}$ and 199-H4-12C (Table 3-3) are similar in magnitude to the estimates generated from the 2009 data, although the positive recharge boundary may be responsible for higher estimate of transmissivity listed for well 199-H4-12C in PNL-6468. 


\section{Conclusions}

General conclusions based on the deep hexavalent chromium study at 100-H Area wells 199-H3-2C, 199-H4-12C, and 199-H4-15CS are presented below:

- Wells 199-H3-2C, 199-H4-12C, and 199-H4-15CS successfully yielded 151.4, 75.7, and 15.1 L/min $(40,20$, and $4 \mathrm{gal} / \mathrm{min})$, respectively. Final specific capacities of these wells were $10.18,15.90$, and $13.04 \mathrm{~L} / \mathrm{min}$ per meter $(0.82,1.28$, and $1.05 \mathrm{gal} / \mathrm{min} / \mathrm{ft})$ of drawdown, respectively. Drawdown at two unconfined aquifer wells near pumping well 199-H3-2C was observed. Drawdown was not observed in the unconfined aquifer near pumping wells $199-\mathrm{H} 4-12 \mathrm{C}$ and 199-H4-15CS.

- Based on the production objective of using no more than 50 percent of available drawdown, the ideal pumping rate for well 199-H3-2C would have been no greater than $90.8 \mathrm{~L} / \mathrm{min}$ ( $24 \mathrm{gal} / \mathrm{min})$. Pumping at well 199-H4-12C could be marginally increased by 5 percent to $79.5 \mathrm{~L} / \mathrm{min}$ (21 gal/min) using the same criterion. Pumping significantly more than $15.1 \mathrm{~L} / \mathrm{min}$ (4 gal $/ \mathrm{min}$ ) from well 199-H4-15CS (a $5.1 \mathrm{~cm}$ [2-in.] well) would likely result in excessive drawdown, although the test used only 8 percent of available drawdown.

- Analysis of the drawdown data indicated transmissivity of tested zones of the RUM ranges from 38.3 to $72.3 \mathrm{~m}^{2} /$ day ( 412 to $778 \mathrm{ft}^{2} /$ day) using the Cooper-Jacob straight-line method. The recovery data were slightly more affected by changes in Columbia River stage but had good correlation to the drawdown data for both wells 199-H3-2C and 199-H4-12C. Changes in Columbia River stage strongly affect groundwater levels in all three confined aquifer wells at ratios, ranging from 0.08 (at well 199-H3-2C) to 0.30 (at well 199-H4-12C). The delay in relation to river stage changes ranged from 13 hours at well 199-H3-2C to less than 30 minutes at well 199-H4-12C.

- Hexavalent chromium concentrations in wells $199-\mathrm{H} 4-12 \mathrm{C}$ (pumping $75.7 \mathrm{~L} / \mathrm{min}$ [20 gal $/ \mathrm{min}$ ] for 43 days) and 199-H4-15CS (pumping $15.1 \mathrm{~L} / \mathrm{min}$ [ $4 \mathrm{gal} / \mathrm{min}$ ] for nearly 6 hours) remained at approximately $100 \mu \mathrm{g} / \mathrm{L}$ during constant-rate pumping tests. Further inland at well 199-H3-2C (pumping $15.1 \mathrm{~L} / \mathrm{min}$ [4 gal/min]), hexavalent chromium concentrations ranged from 5 to $52 \mu \mathrm{g} / \mathrm{L}$ (generally increasing) during the 43-day constant-rate pumping test.

- A water-level drawdown response of $0.2 \mathrm{~m}(0.7 \mathrm{ft})$ in the unconfined aquifer resulted from pumping a shallow RUM water-bearing zone for 42.3 days at well 199-H3-2C. The recovery response confirmed the hydraulic connection at this inland location. Examination of the borehole log for well 199-H3-2C suggests that layered RUM sediments with possibly higher permeability separate the screened zone from the unconfined aquifer, and leakage through these sediments accounts for the positive recharge boundary during the pumping test as well as the gradual drawdown in the unconfined aquifer. Groundwater mounding near the $\mathrm{H}$ Reactor or at the $183-\mathrm{H}$ solar evaporation basins may have provided enough head to allow hexavalent chromium to enter permeable seams within the RUM that may be exposed to the unconfined aquifer beneath this area.

- The pumping test data sets, including groundwater-level data from upper unconfined zones at all three test locations and lower zones at the 199-H4-15 nested well site, did not indicate borehole leakage effects (i.e., the data did not show evidence that the pumping well boreholes were acting as conduits for the exchange of groundwater between different water-bearing zones). The data indicated that possible recharge boundaries may have strongly influenced the mid- to late drawdown data for wells 199-H3-2C and 199-H4-12C. Late-time leakage through RUM aquitards below and possibly above the zone tapped by well 199-H4-15CS appears to have influenced the drawdown in 
well 199-H4-15CS. Partial penetration effects appear to affect data at this well due to the short screen length relative to the thickness of the water-bearing zone.

- Comparison of historic and recent groundwater levels in well 199-H4-15 nested piezometers suggests the steepness of the upward vertical gradient has decreased in recent years. This decrease in vertical gradient may help explain concentration trends in both the confined RUM and unconfined aquifer zones.

- While the rebound study showed that most monitoring wells sampled within the 100-H Area did not have a significant change in hexavalent chromium concentrations, at least one well (far-field well 199-H4-48) did show an increase when the P\&T system was shut down. From June to October 2009, hexavalent chromium concentrations increased from 5.2 to $38.6 \mu \mathrm{g} / \mathrm{L}$. However, after average river stage climbed in November 2009 and the P\&T system was restarted, hexavalent chromium concentration declined sharply at well 199-H4-48.

- Of the pumped wells, only 199-H4-12C displayed a consistent trend of increasing hexavalent chromium concentration during the constant-rate pumping test (Figure 2-18). The increase of 10 to 20 percent is not indicative of any particular source of the hexavalent chromium, and it is consistent with generally widespread occurrence of trace hexavalent chromium in the confined RUM waterbearing zones in the vicinity of the 100-H Area.

- Inspection of hexavalent chromium concentration versus time (Figures 2-20 through 2-22) does not indicate any clear concentration trends for hexavalent chromium in unconfined aquifer monitoring wells subsequent to temporary shutdown of the 100-H Area P\&T system. Therefore, there is no support for any significant rebound of hexavalent chromium concentrations.

- The results suggest that the most likely explanation for the origin of the hexavalent chromium in the RUM at the $100-\mathrm{H}$ Area is from contaminated water that had passed through the reactor for cooling with up to $1 \mathrm{ppm}$ hexavalent chromium and was subsequently discharged to the ground in sufficient quantities to form a mound. This mound provided sufficient hydraulic driving force to push into the upper RUM and mix with existing groundwater in the RUM, resulting in concentrations of one-tenth to one-thirtieth of the original cooling water. Concentrations decline inland, suggesting that a $100-\mathrm{H}$ Area source is persistent and that cross-contamination via well bores is unlikely.

- The results suggest that the zone of contamination has a finite areal extent, which can be remediated using P\&T. Further characterization will be conducted via P\&T. 


\section{References}

Comprehensive Environmental Response, Compensation, and Liability Act of 1980, 42 USC 9601, et seq. Available at: http://uscode.house.gov/download/pls/42C103.txt.

Cooper, H.H. and C.E. Jacob, 1946, "A Generalized Graphical Method for Evaluating Formation Constants and Summarizing Well Field History," Trans. Am. Geophys. Union, 27:524-526.

DOE/RL-2006-20, 2006, The Second CERCLA Five-Year Review Report for the Hanford Site, Rev. 1, U.S. Department of Energy, Richland Operations Office, Richland, Washington. Available at: http://www5.hanford.gov/arpir/?content=findpage\&AKey=DA04570094.

DOE/RL-2008-42, 2009, Hydrogeological Summary Report for 600 Area Between 100-D and 100-H for the 100-HR-3 Groundwater Operable Unit, Rev. 0, U.S. Department of Energy, Richland Operations Office, Richland, Washington. Available at:

http://www2.hanford.gov/arpir/?content=findpage\&AKey=0911161139.

Driscol, F.G., 1986, Groundwater and Wells, Second Edition, Johnson Division, St. Paul, Minnesota.

Ecology Publication 94-06, 2007, Model Toxics Control Act Cleanup Statute and Regulation, as revised, Washington State Department of Ecology, Olympia, Washington. Available at: http://www.ecy.wa.gov/pubs/9406.pdf

GRP-FS-04-G-001, Chromium Analysis of Water Samples at Pump and Treat Facilities, CH2M HILL Plateau Remediation Company, Richland, Washington.

PNL-6468, 1987, Ground-Water Monitoring Compliance Projects for Hanford Site Facilities, Progress Report for the Period April 1 to June 30, 1987, Rev. 0, Pacific Northwest Laboratory, Richland, Washington. Available at:

http://www2.hanford.gov/ARPIR/?content=findpage\&AKey=D196104305.

SGW-41302, 2009, Description of Work for Aquifer Testing in Support of the 100-H Deep Chromium Investigation, Rev. 0 Reissue, CH2M HILL Plateau Remediation Company, Richland, Washington. Available at:

http://www5.hanford.gov/arpir/?content=findpage\&AKey=0909081364.

Theis, C.V., 1963, Estimating the Transmissivity of a Water Table Aquifer from the Specific Capacity of a Well, U.S. Geological Survey, Water Supply Paper 1536-I, pp. 332-336. 
SGW-47776, REV. 0 
SGW-47776, REV. 0

\section{Appendix A}

Test Well Construction Logs and Pump-and-Treat System Map 
SGW-47776, REV. 0 
SGW-47776, REV. 0

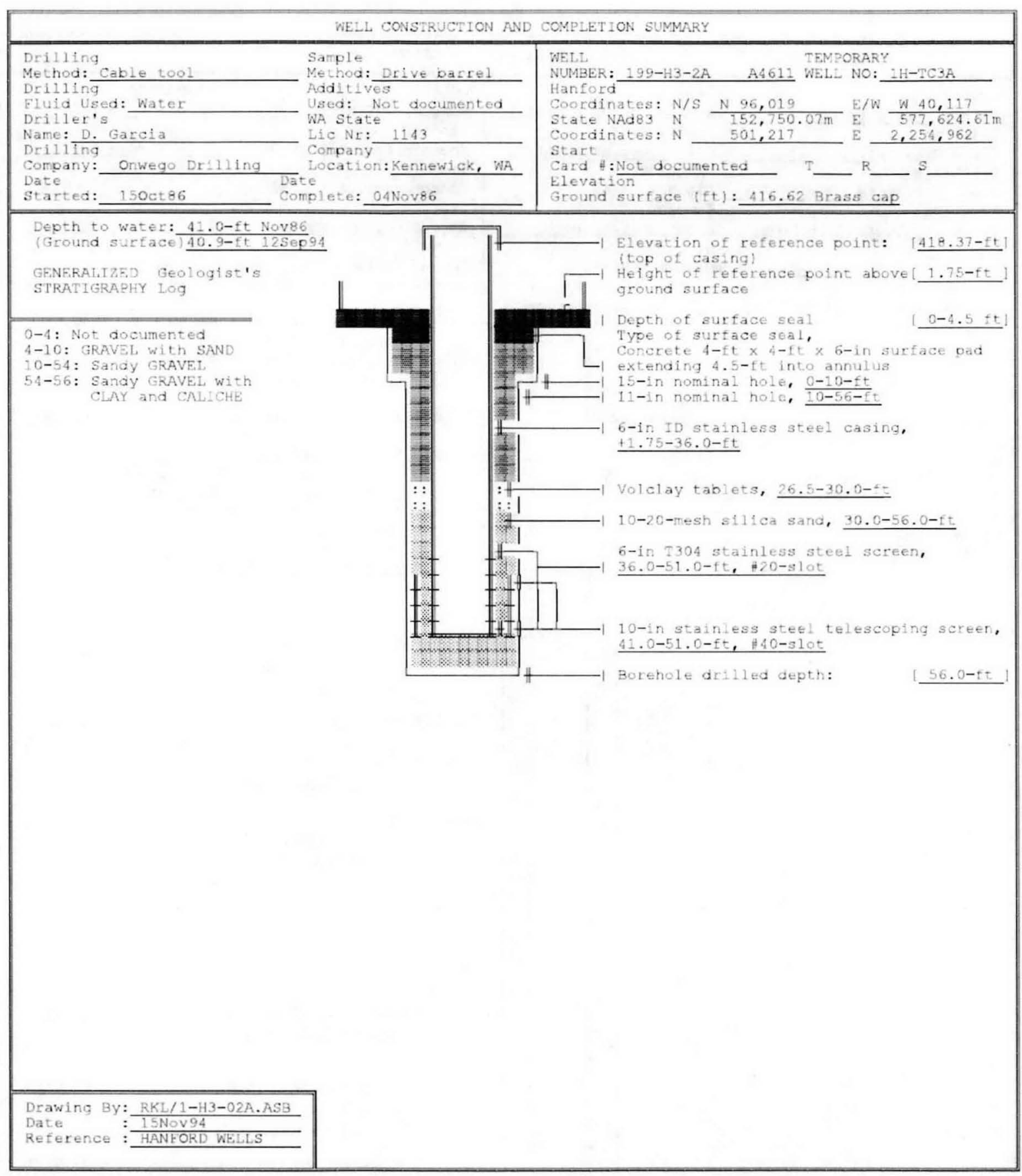




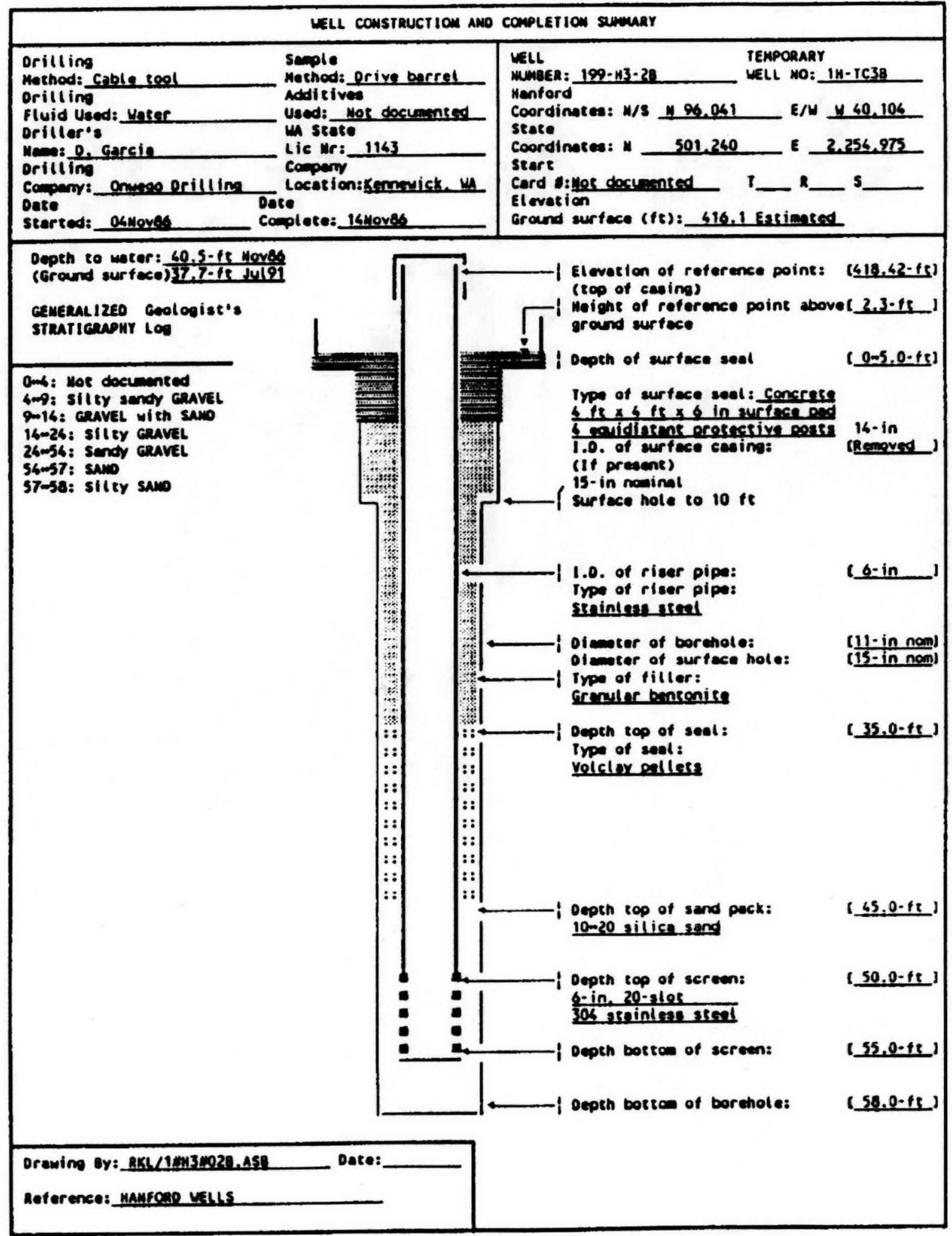




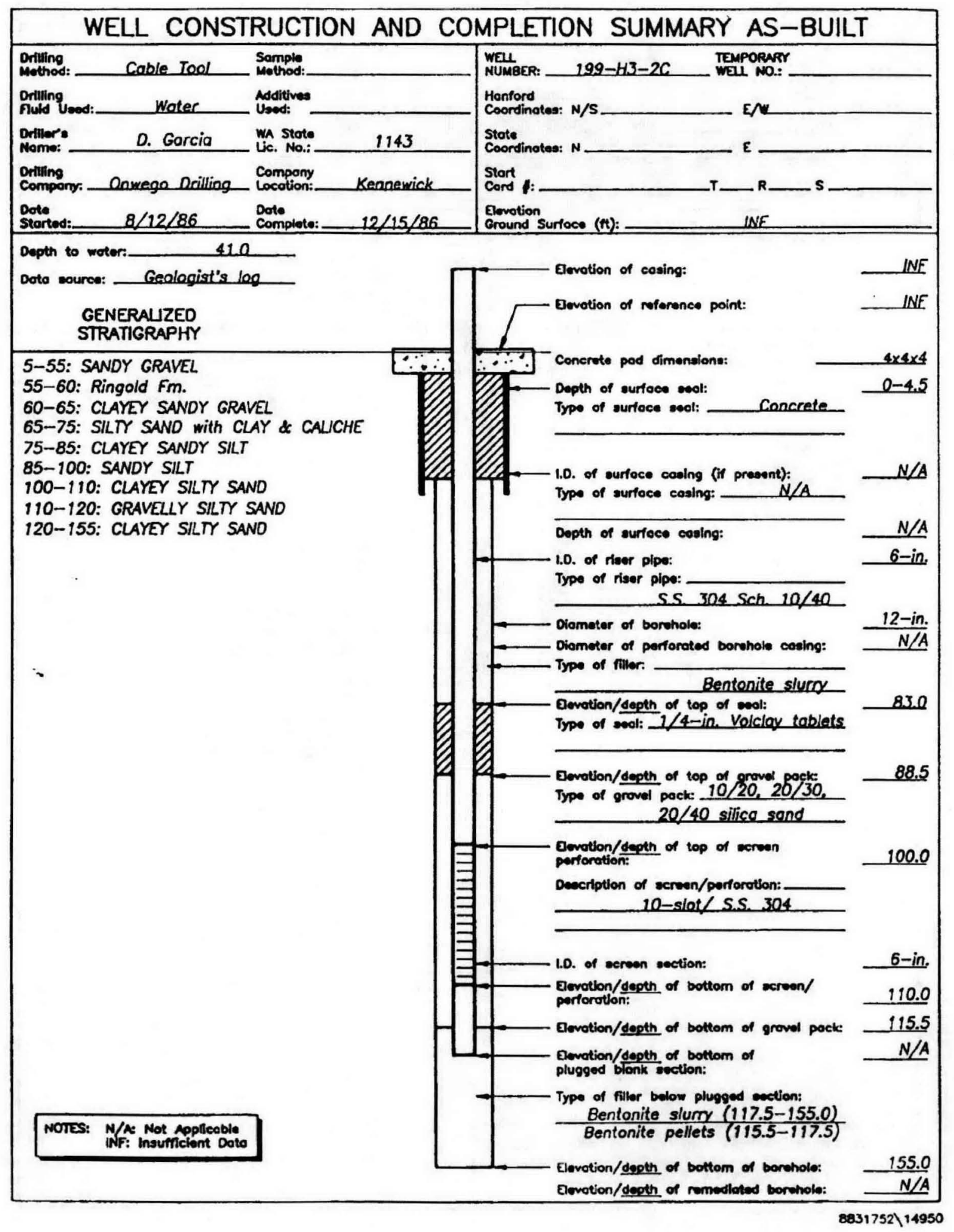




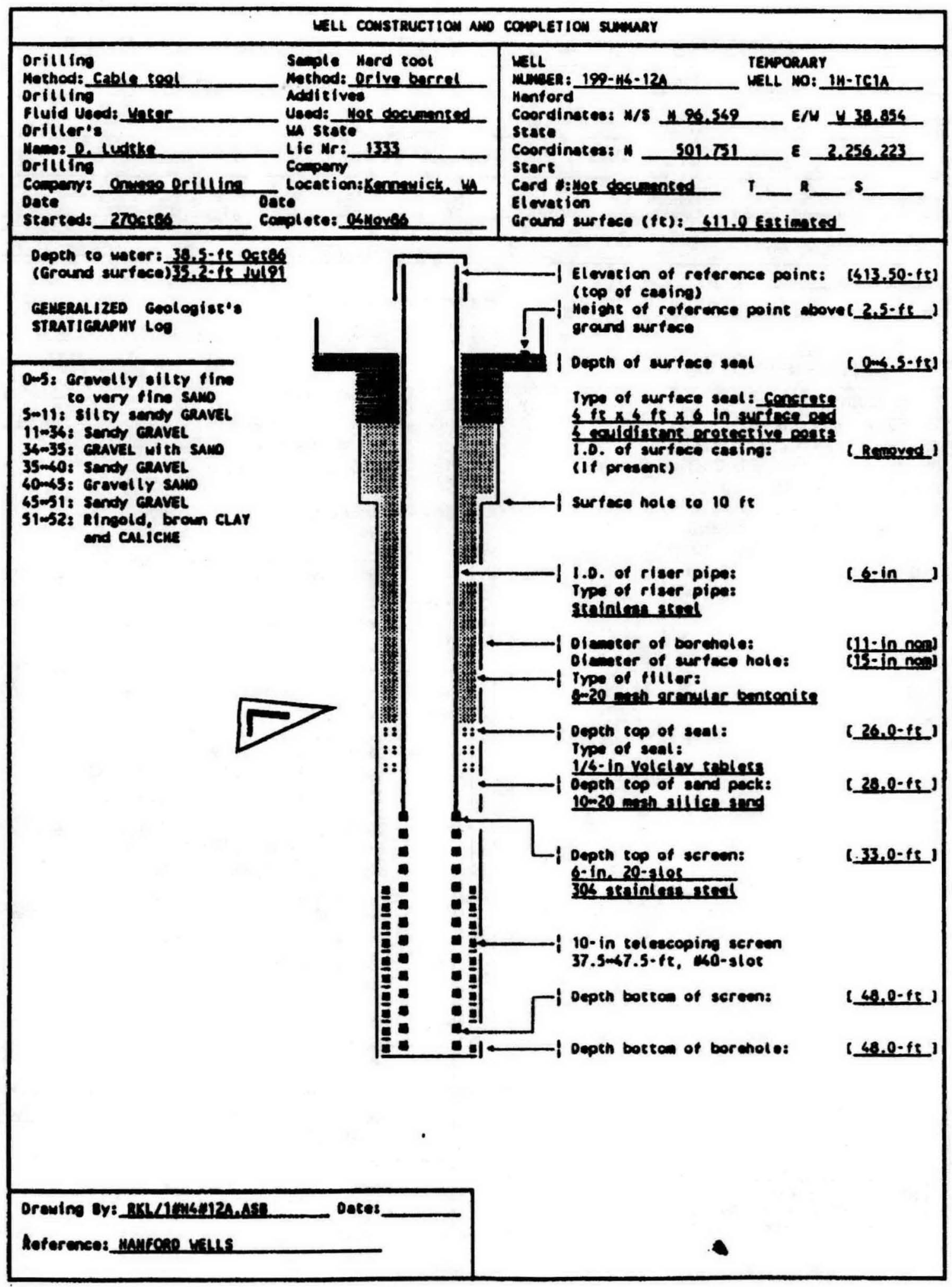




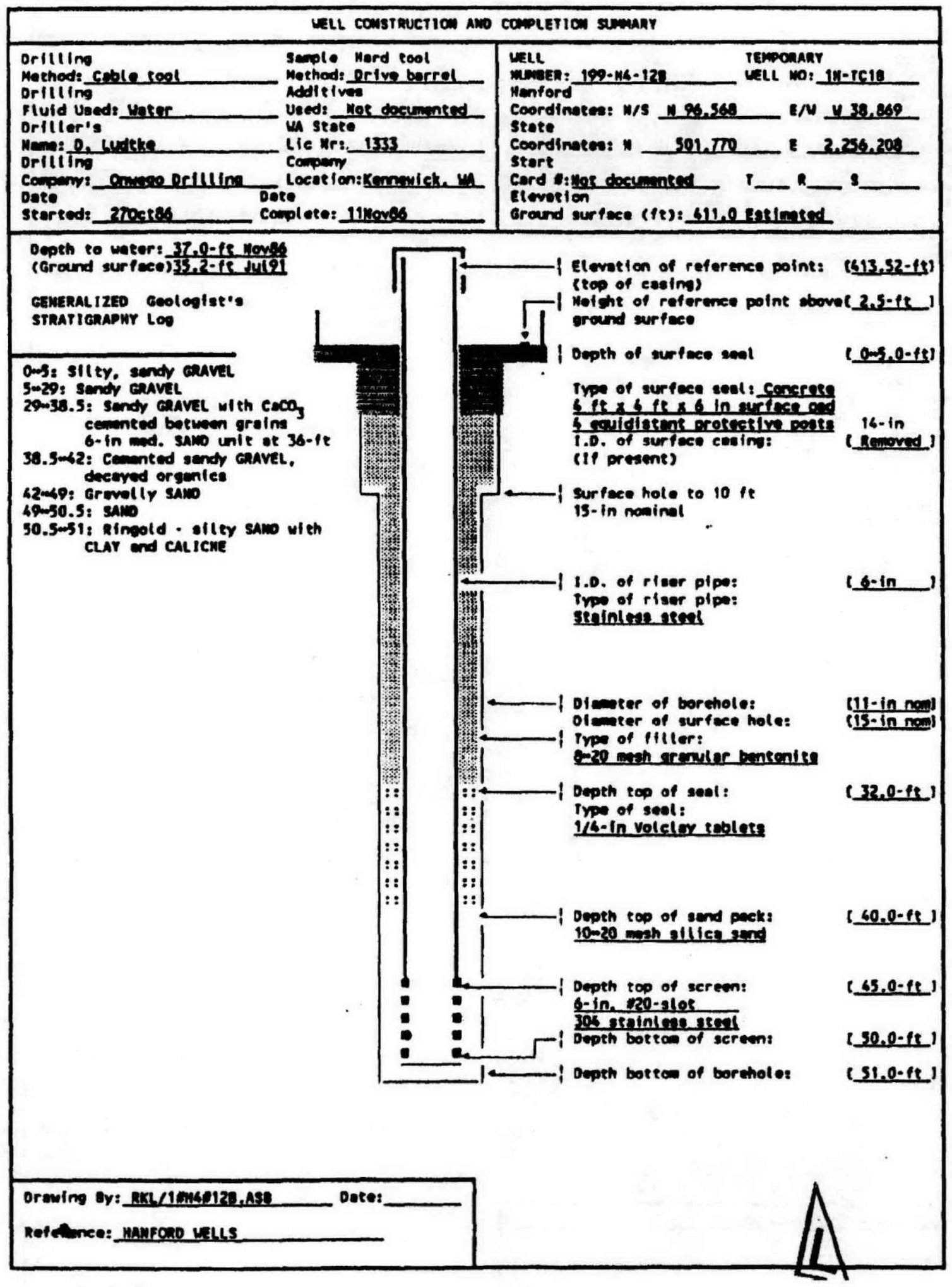




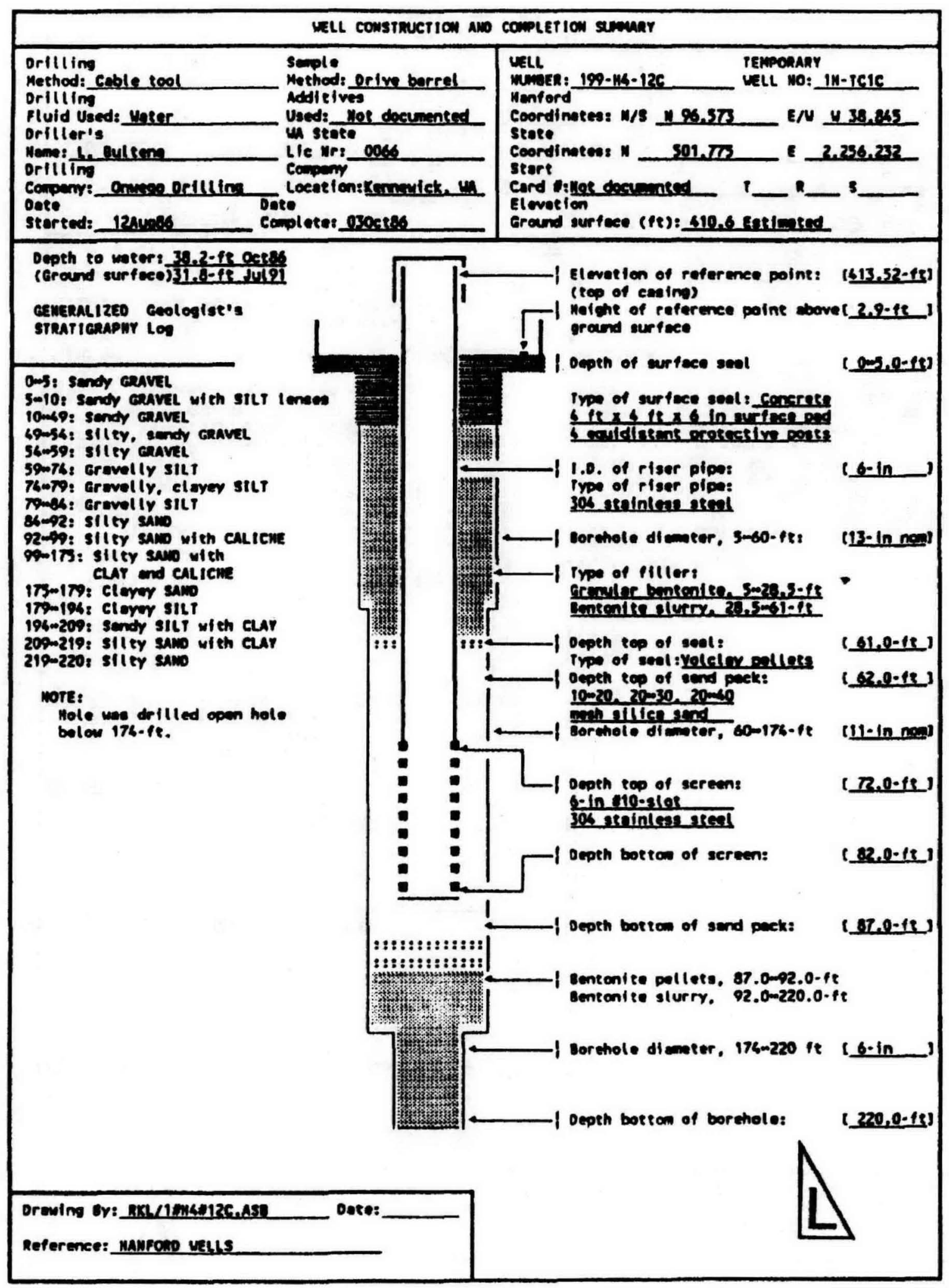




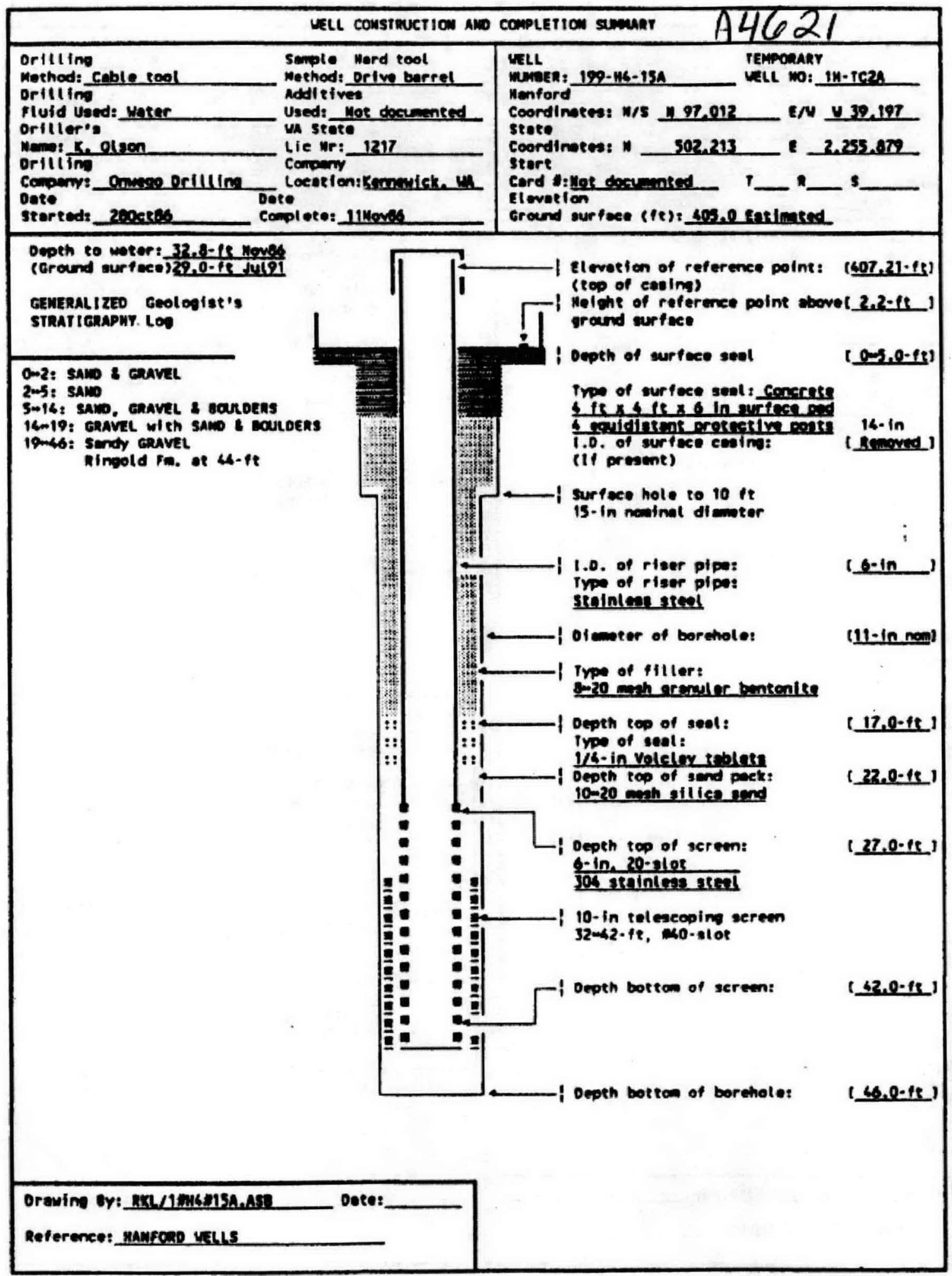




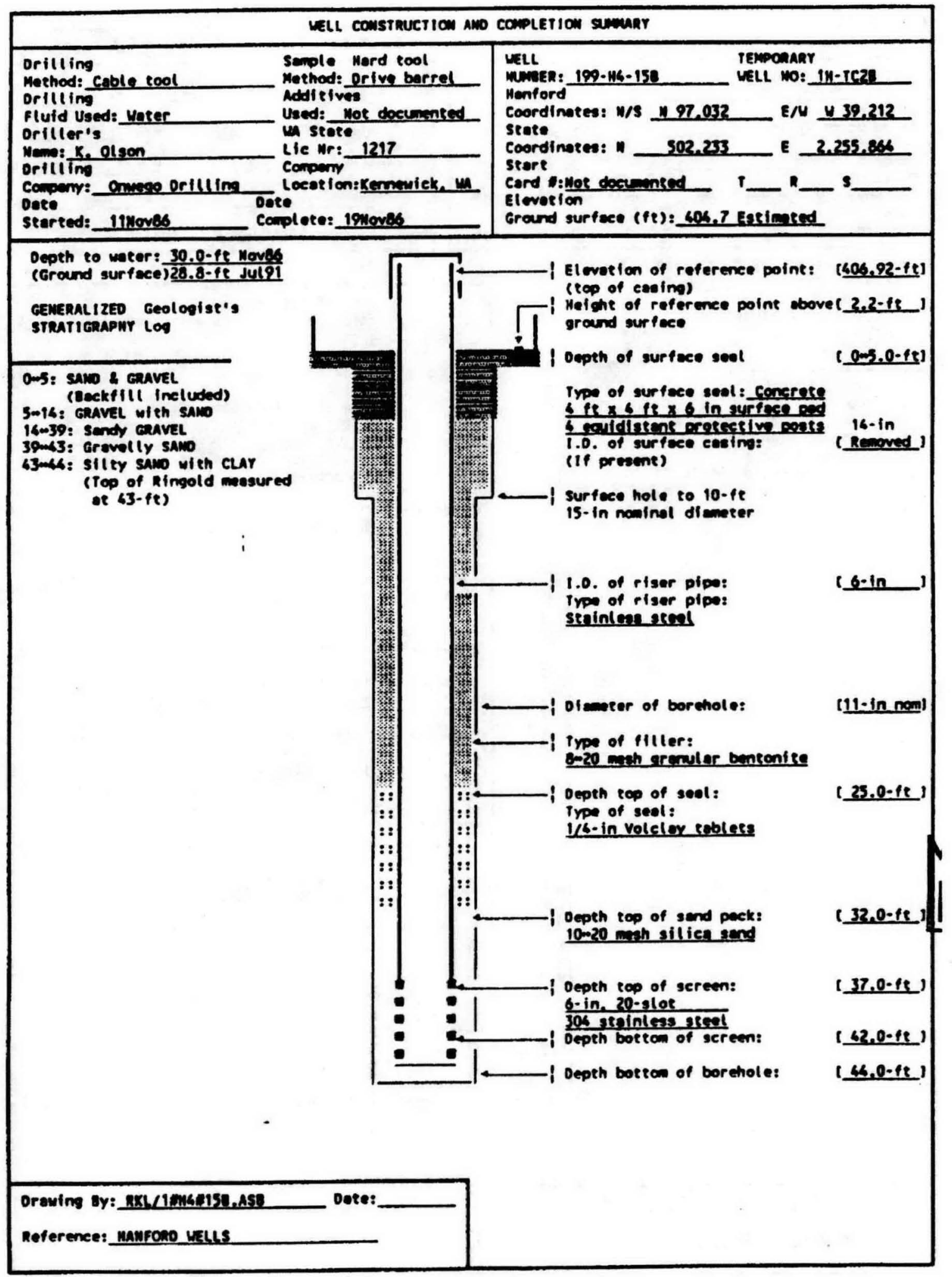




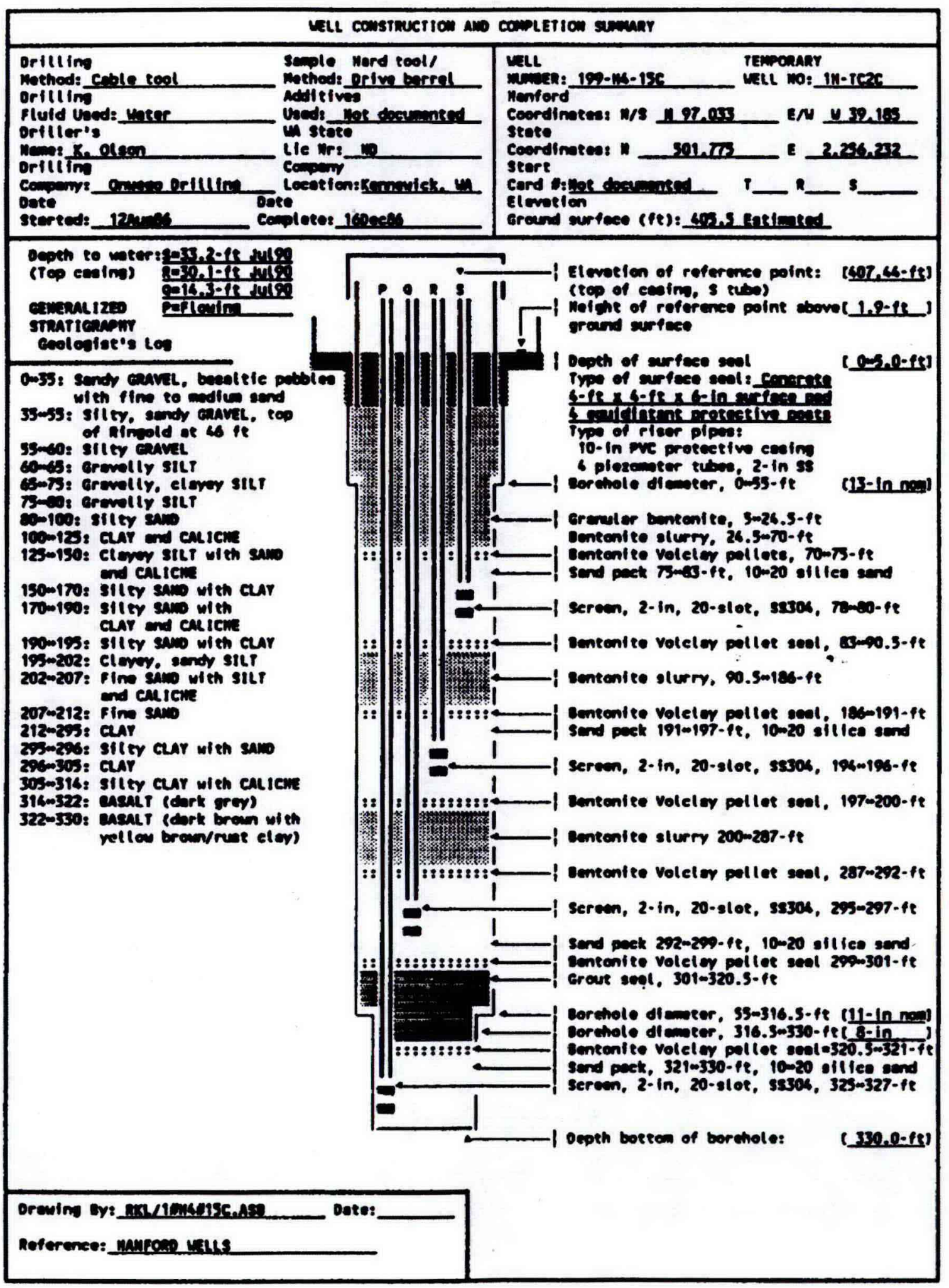




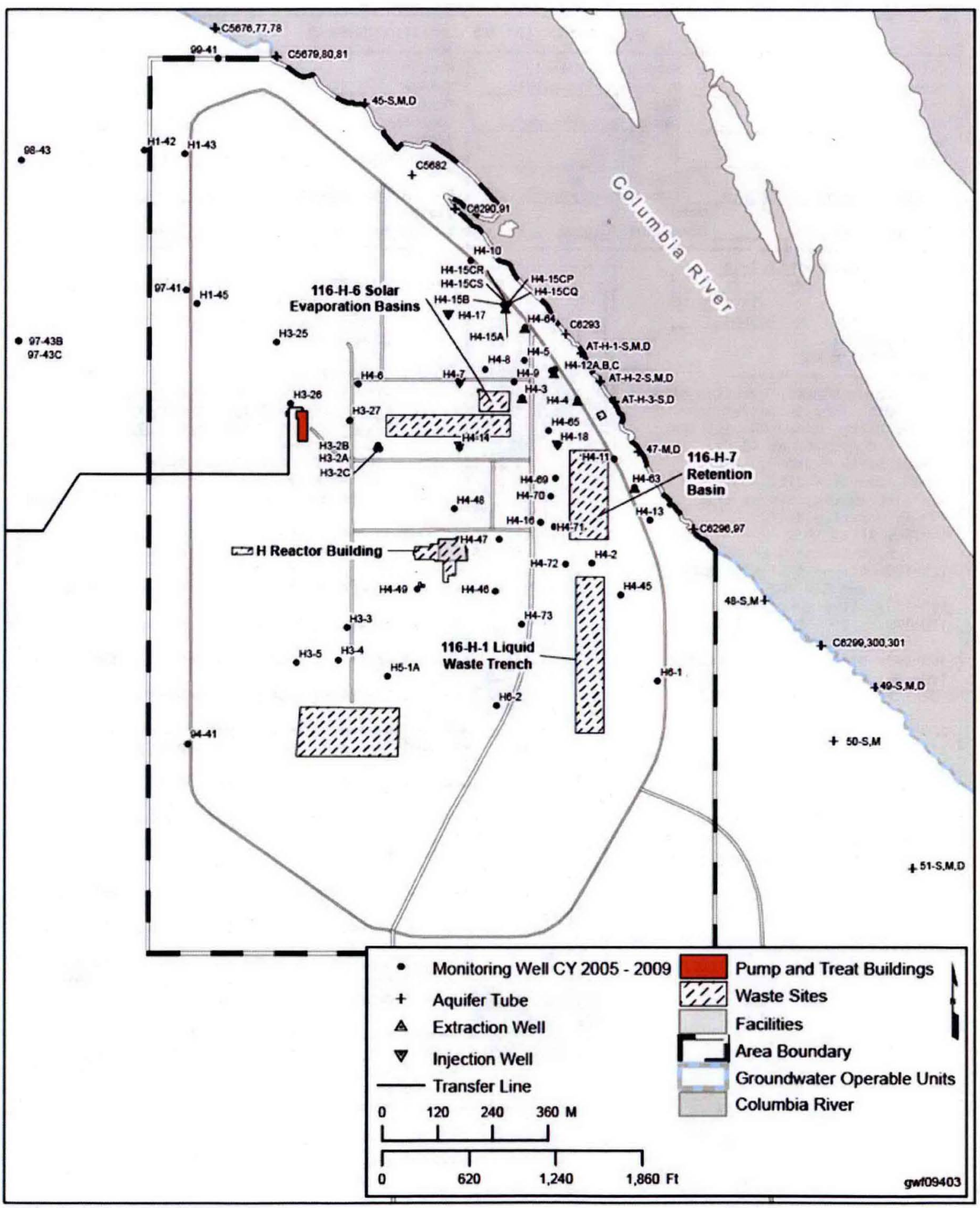

Source: DOE/RL-2010-11, Hanford Site Groundwater Monitoring and Performance Report for 2009. 
SGW-47776, REV. 0

\section{Reference}

DOE/RL-2010-11, 2010, Hanford Site Groundwater Monitoring and Performance Report for 2009, Volumes 1 \& 2, Rev. 1, U.S. Department of Energy, Richland Operations Office, Richland, Washington. 
SGW-47776, REV. 0

A-12 
SGW-47776, REV. 0

\section{Appendix B}

Step-Drawdown and Constant-Rate Sample Results 
SGW-47776, REV. 0

B-ii 
SGW-47776, REV. 0

Table B-1. Well 199-H3-2C Step-Drawdown Test Sample Results

\begin{tabular}{|c|c|c|c|c|c|c|c|}
\hline $\begin{array}{l}\text { Pumping } \\
\text { Time } \\
\text { (min) }\end{array}$ & Time & $\begin{array}{c}\text { Pump } \\
\text { Rate } \\
\text { (gal/min) }\end{array}$ & $\begin{array}{c}\text { Hexavalent } \\
\text { Chromium } \\
(\mathrm{mg} / \mathrm{L})\end{array}$ & $\begin{array}{c}\text { Turbidity } \\
\text { (NTU) }\end{array}$ & $\begin{array}{l}\text { Cond. } \\
(\mu \mathrm{S} / \mathrm{cm})\end{array}$ & $\begin{array}{c}\text { Temp. } \\
\text { (C) }\end{array}$ & pH \\
\hline 0 & $09: 15$ & 0 & -- & - & -- & -- & -- \\
\hline 5 & 09:20 & 10.4 & 0.039 & -- & -- & - & - \\
\hline 18 & $09: 33$ & 10.4 & 0.028 & -- & -- & -- & -- \\
\hline 40 & $09: 55$ & 10.6 & 0.021 & -- & -- & -- & -- \\
\hline 45 & $10: 00$ & 10.4 & 0.019 & -- & -- & -- & -- \\
\hline 60 & $10: 15$ & 10.6 & 0.016 & -- & -- & -- & -- \\
\hline 110 & $11: 05$ & 10.6 & 0.014 & 0.94 & 247.6 & 23.4 & 8.05 \\
\hline 115 & $11: 10$ & 20.8 & 0.015 & -- & -- & -- & -- \\
\hline 125 & $11: 20$ & 20.6 & 0.021 & -- & -- & -- & -- \\
\hline 140 & $11: 35$ & 20.6 & 0.015 & -- & -- & -- & -- \\
\hline 155 & $11: 50$ & 20.6 & 0.013 & -- & -- & -- & -- \\
\hline 170 & $12: 05$ & 20.6 & 0.013 & -- & -- & -- & -- \\
\hline 230 & $13: 05$ & 20.6 & 0.012 & 0.64 & 254.1 & 23.2 & 8.03 \\
\hline 237 & $13: 12$ & 40.9 & 0.022 & -- & -- & -- & -- \\
\hline 245 & $13: 20$ & 41 & 0.016 & -- & -- & -- & -- \\
\hline 262 & $13: 37$ & 41 & 0.011 & -- & -- & -- & -- \\
\hline 277 & $13: 52$ & 40.8 & 0.011 & -- & -- & -- & -- \\
\hline 292 & $14: 07$ & 40.8 & 0.009 & -- & -- & -- & -- \\
\hline 352 & $15: 07$ & 40.2 & 0.009 & 0.64 & 270.8 & 23.2 & 8.05 \\
\hline 359 & $15: 14$ & $\begin{array}{l}\text { Pump } \\
\text { shut off }\end{array}$ & -- & -- & -- & -- & -- \\
\hline
\end{tabular}


SGW-47776, REV. 0

Table B-2. Well 199-H4-12C Step-Drawdown Test Sample Results

\begin{tabular}{|c|c|c|c|c|c|c|c|}
\hline $\begin{array}{c}\text { Pumping } \\
\text { Time } \\
\text { (min) }\end{array}$ & Time & $\begin{array}{c}\text { Pump } \\
\text { Rate } \\
\text { (gal/min) }\end{array}$ & $\begin{array}{c}\text { Hexavalent } \\
\text { Chromium } \\
(\mathrm{mg} / \mathrm{L})\end{array}$ & $\begin{array}{c}\text { Turbidity } \\
\text { (NTU) }\end{array}$ & $\begin{array}{c}\text { Cond. } \\
(\mu \mathrm{S} / \mathrm{cm})\end{array}$ & $\begin{array}{c}\text { Temp. } \\
\left({ }^{\circ} \mathrm{C}\right)\end{array}$ & pH \\
\hline 0 & 09:10 & 0 & -- & -- & -- & -- & -- \\
\hline 5 & 09:15 & 5.5 & 0.098 & -- & -- & -- & -- \\
\hline 14 & 09:24 & 5.5 & 0.099 & -- & -- & -- & -- \\
\hline 28 & 09:38 & 5.5 & 0.095 & - & -- & -- & -- \\
\hline 43 & 09:53 & 5.5 & 0.1 & -- & -- & - & -- \\
\hline 110 & $11: 00$ & 10.1 & 0.099 & 0.49 & 257.9 & 22.4 & 7.85 \\
\hline 121 & 11:11 & 10.3 & 0.104 & -- & -- & -- & -- \\
\hline 129 & $11: 19$ & 10.1 & 0.105 & -- & -- & -- & -- \\
\hline 144 & 11:34 & 9.9 & 0.106 & -- & -- & -- & -- \\
\hline 158 & $11: 48$ & 20.2 & 0.105 & -- & -- & -- & -- \\
\hline 231 & 13:01 & 20.3 & 0.099 & 0.59 & 250 & 20.8 & 8.1 \\
\hline 240 & $13: 10$ & 20.3 & 0.101 & -- & -- & -- & -- \\
\hline 249 & $13: 19$ & 20.2 & 0.103 & -- & -- & -- & -- \\
\hline 277 & $13: 47$ & 20.2 & 0.105 & -- & -- & -- & -- \\
\hline 347 & $14: 57$ & 20.2 & 0.095 & 0.57 & 248 & 21.2 & 8.11 \\
\hline 355 & $15: 05$ & $\begin{array}{l}\text { Pump } \\
\text { shut off }\end{array}$ & -- & -- & -- & -- & -- \\
\hline
\end{tabular}


SGW-47776, REV. 0

Table B-3. Well 199-H4-15CS Step-Drawdown Test Sample Results

\begin{tabular}{|c|c|c|c|c|c|c|c|}
\hline $\begin{array}{c}\text { Pumping } \\
\text { Time } \\
(\mathbf{m i n})\end{array}$ & $\begin{array}{c}\mathbf{1 0 / 2 7 / 2 0 0 9} \\
\text { Time }\end{array}$ & $\begin{array}{c}\text { Pump } \\
\text { Rate } \\
(\mathrm{gal} / \mathbf{m i n})\end{array}$ & $\begin{array}{c}\text { Hexavalent } \\
\text { Chromium } \\
(\mathbf{m g} / \mathbf{L})\end{array}$ & $\begin{array}{c}\text { Turbidity } \\
(\mathbf{N T U})\end{array}$ & $\begin{array}{c}\text { Cond. } \\
(\boldsymbol{\mu} \mathbf{S} / \mathbf{c m})\end{array}$ & $\begin{array}{c}\text { Temp. } \\
(\mathbf{C})\end{array}$ & $\mathbf{p H}$ \\
\hline 0 & $07: 38$ & 0 & -- & -- & -- & -- & -- \\
\hline 5 & $07: 43$ & 2 & 0.106 & -- & -- & -- & -- \\
\hline 10 & $07: 48$ & 3 & 0.108 & 28 & 285 & 15.3 & 7.45 \\
\hline 30 & $08: 08$ & 3 & 0.108 & 0.6 & 273 & 16.7 & 8.03 \\
\hline 45 & $08: 23$ & 3 & 0.109 & -- & -- & -- & -- \\
\hline 60 & $08: 38$ & 3 & 0.106 & -- & -- & -- & -- \\
\hline 120 & $09: 38$ & 3 & 0.103 & 0.32 & 272 & 18.3 & 8.14 \\
\hline 133 & $09: 51$ & 4 & 0.102 & 0.36 & 280 & 18.6 & 8.01 \\
\hline 143 & $10: 01$ & 4 & 0.102 & -- & -- & -- & -- \\
\hline 158 & $10: 16$ & 4 & 0.103 & 0.27 & 278 & 18.9 & 8.17 \\
\hline 173 & $10: 31$ & 4 & 0.102 & -- & -- & -- & -- \\
\hline 188 & $10: 46$ & 4 & 0.104 & 0.39 & 265 & 19.1 & 8.2 \\
\hline 248 & $11: 46$ & 4 & 0.104 & 0.32 & 269 & 18.9 & 8.22 \\
\hline 368 & $13: 46$ & 4 & 0.104 & 0.62 & 265 & 19.1 & 8.25 \\
\hline 428 & $14: 46$ & $\begin{array}{c}\text { Pump } \\
\text { shut off }\end{array}$ & 0.108 & 0.5 & 266 & 19.1 & 8.24 \\
\hline
\end{tabular}


Table B-4. Chemical Sample Data for Constant-Rate Aquifer Test at Well 199-H3-2C

\begin{tabular}{|c|c|c|c|c|c|c|}
\hline $\begin{array}{l}\text { Sample Date } \\
\text { (Time) }\end{array}$ & $\begin{array}{c}\text { Hexavalent } \\
\text { Chromium } \\
(\mathrm{mg} / \mathrm{L})\end{array}$ & $\begin{array}{c}\text { Laboratory Results } \\
\text { for Hexavalent } \\
\text { Chromium } \\
(\mathrm{mg} / \mathrm{L})\end{array}$ & $\begin{array}{c}\text { Turbidity } \\
\text { (NTU) }\end{array}$ & pH & $\begin{array}{l}\text { Temp. } \\
\text { ('C) }\end{array}$ & $\begin{array}{l}\text { Cond. } \\
(\mu S / \mathrm{cm})\end{array}$ \\
\hline $9 / 21 / 2009(09: 33)$ & 0.006 & -- & 2.12 & 7.83 & 19.3 & 259.8 \\
\hline $9 / 21 / 2009(09: 43)$ & 0.018 & -- & 2.12 & 7.19 & 19.5 & 302.6 \\
\hline $9 / 21 / 2009(09: 58)$ & 0.016 & 0.0102 & 2.79 & 7.77 & 19.9 & 329.7 \\
\hline $9 / 21 / 2009(10: 14)$ & 0.016 & -- & 2.03 & 7.79 & 19.9 & 265.8 \\
\hline $9 / 21 / 2009(10: 29)$ & 0.019 & -- & 1.53 & 7.94 & 19.6 & 272.8 \\
\hline $9 / 21 / 2009(11: 29)$ & 0.026 & -- & 4.54 & 7.93 & 20.1 & 257.4 \\
\hline $9 / 21 / 2009(13: 29)$ & 0.018 & -- & 0.37 & 7.6 & 20.7 & 259.3 \\
\hline $9 / 21 / 2009(15: 00)$ & 0.014 & $\begin{array}{c}0.0109 \\
\text { (duplicate 0.0107) }\end{array}$ & 0.57 & 6.98 & 20.5 & 256.4 \\
\hline $9 / 22 / 2009(13: 49)$ & 0.007 & -- & N/D & 7.8 & 21.5 & 462 \\
\hline $9 / 23 / 2009(12: 30)$ & 0.005 & -- & 0.23 & 8.05 & 21.8 & 257 \\
\hline $9 / 24 / 2009(12: 45)$ & 0.018 & -- & 0.51 & 7.77 & 21.8 & 792 \\
\hline $9 / 25 / 2009(08: 35)$ & 0.018 & -- & 1.76 & 7.95 & 20.7 & 250 \\
\hline $9 / 25 / 2009(10: 00)$ & 0.019 & -- & 0.14 & 8.05 & 20.4 & 240 \\
\hline $9 / 26 / 2009(08: 45)$ & 0.030 & -- & 5.19 & 7.31 & 20.3 & 238 \\
\hline $9 / 27 / 2009(05: 45)$ & 0.018 & -- & 0.69 & 7.8 & 19 & 241 \\
\hline $9 / 29 / 2009(14: 36)$ & 0.023 & -- & 0.24 & 7.83 & 20.1 & 266 \\
\hline $9 / 30 / 2009(10: 00)$ & 0.023 & $\begin{array}{c}0.0304 \\
\text { (duplicate } 0.0305 \text { ) }\end{array}$ & 0.13 & 8.1 & 20.4 & 244 \\
\hline $10 / 1 / 2009(11: 20)$ & 0.035 & 0.0350 & 0.35 & 8.07 & 20.1 & 233.7 \\
\hline $10 / 2 / 2009(07: 00)$ & 0.030 & -- & 41.9 & 8.2 & 17.9 & 232.2 \\
\hline $10 / 3 / 2009(06: 20)$ & 0.037 & -- & 1.83 & 8.11 & 18.3 & 233.3 \\
\hline $10 / 4 / 2009(07: 00)$ & 0.044 & -- & 0.87 & 7.84 & 19.6 & 236.8 \\
\hline $10 / 5 / 2009(13: 50)$ & 0.990 & -- & 35.2 & 7.92 & 21.5 & 783.9 \\
\hline $10 / 6 / 2009(10: 51)$ & 0.052 & 0.0287 & 10.6 & 8.2 & 20.7 & 236.3 \\
\hline $10 / 7 / 2009(08: 40)$ & 0.045 & -- & 4.59 & 8.16 & 19.4 & 237.6 \\
\hline $10 / 8 / 2009(09: 00)$ & 0.04 & -- & 6.57 & 8.05 & 19.8 & 236.9 \\
\hline
\end{tabular}


SGW-47776, REV. 0

Table B-4. Chemical Sample Data for Constant-Rate Aquifer Test at Well 199-H3-2C

\begin{tabular}{|c|c|c|c|c|c|c|}
\hline $\begin{array}{l}\text { Sample Date } \\
\text { (Time) }\end{array}$ & $\begin{array}{l}\text { Hexavalent } \\
\text { Chromium } \\
\text { (mg/L) }\end{array}$ & $\begin{array}{c}\text { Laboratory Results } \\
\text { for Hexavalent } \\
\text { Chromium } \\
(\mathbf{m g} / \mathrm{L})\end{array}$ & $\begin{array}{c}\text { Turbidity } \\
\text { (NTU) }\end{array}$ & pH & $\begin{array}{l}\text { Temp. } \\
\text { (C) }\end{array}$ & $\begin{array}{l}\text { Cond. } \\
(\mu \mathrm{S} / \mathrm{cm})\end{array}$ \\
\hline $10 / 9 / 2009(08: 08)$ & 0.03 & 0.0335 & 0.49 & 8.06 & 20.3 & 237.4 \\
\hline $10 / 10 / 2009(06: 50)$ & 0.033 & -- & 0.07 & 7.89 & 18.1 & 237.7 \\
\hline $10 / 11 / 2009(10: 00)$ & 0.032 & -- & 0.15 & 7.59 & 19.1 & 254 \\
\hline $10 / 12 / 2009(09: 30)$ & 0.033 & -- & 0.61 & 8.01 & 19.5 & 234.9 \\
\hline $10 / 13 / 2009(08: 15)$ & 0.029 & 0.0349 & 0.14 & 8.12 & 20.8 & 244 \\
\hline $10 / 14 / 2009(09: 45)$ & 0.028 & -- & 0.17 & 8.13 & 19.2 & 244.1 \\
\hline $10 / 15 / 2009(10: 21)$ & 0.021 & -- & 0.06 & 8.05 & 20.6 & 244.6 \\
\hline $10 / 16 / 2009(06: 00)$ & 0.024 & -- & 0.06 & 7.24 & 19.1 & 249.1 \\
\hline $10 / 17 / 2009(06: 00)$ & 0.03 & $\therefore$ & 0.05 & 7.71 & 18.7 & 240.3 \\
\hline $10 / 18 / 2009(07: 43)$ & 0.031 & -- & 0.07 & 7.95 & 18.1 & 250.9 \\
\hline $10 / 19 / 2009(08: 28)$ & 0.031 & -- & 0.21 & 7.92 & 19.3 & 243.2 \\
\hline $10 / 20 / 2009(10: 25)$ & 0.033 & 0.0331 & 0.25 & 7.81 & 20.9 & 252 \\
\hline $10 / 21 / 2009(10: 40)$ & 0.031 & -- & 0.21 & 7.73 & 21.9 & 253 \\
\hline $10 / 22 / 2009(09: 30)$ & 0.032 & -- & 0.26 & 7.88 & 21.2 & 250 \\
\hline $10 / 23 / 2009(06: 50)$ & 0.031 & $\begin{array}{c}0.0337 \\
\text { (duplicate } 0.0333 \text { ) }\end{array}$ & 0.09 & 7.89 & 20.8 & 243 \\
\hline $10 / 24 / 2009(09: 00)$ & 0.033 & -- & 0.16 & 7.81 & 20.7 & 254 \\
\hline $10 / 25 / 2009(06: 30)$ & 0.03 & -- & 0.21 & 7.8 & 19.2 & 252 \\
\hline $10 / 26 / 2009(09: 40)$ & 0.027 & -- & 0.11 & 7.81 & 20.4 & 251 \\
\hline $10 / 27 / 2009(11: 32)$ & 0.03 & -- & 0.18 & 7.86 & 20.1 & 245 \\
\hline $11 / 3 / 2009(15: 02)$ & 0.037 & -- & 0.16 & 7.33 & 20.1 & 265 \\
\hline
\end{tabular}


SGW-47776, REV. 0

Table B-5. Chemical Sample Data for Constant-Rate Aquifer Test at Well 199-H4-12C

\begin{tabular}{|c|c|c|c|c|c|c|}
\hline $\begin{array}{l}\text { Sample Date } \\
\text { (Time) }\end{array}$ & $\begin{array}{c}\text { Hexavalent } \\
\text { Chromium } \\
(\mathrm{mg} / \mathrm{L})\end{array}$ & $\begin{array}{c}\text { Laboratory Results } \\
\text { for Hexavalent } \\
\text { Chromium } \\
(\mathrm{mg} / \mathrm{L})\end{array}$ & $\begin{array}{c}\text { Turbidity } \\
\text { (NTU) }\end{array}$ & pH & $\begin{array}{l}\text { Temp. } \\
\left({ }^{\circ} \mathrm{C}\right)\end{array}$ & $\begin{array}{l}\text { Cond. } \\
(\mu \mathrm{S} / \mathrm{cm})\end{array}$ \\
\hline $9 / 21 / 2009(09: 44)$ & 0.098 & -- & 2.47 & 7.8 & 20.2 & 258.3 \\
\hline $9 / 21 / 2009(09: 54)$ & 0.097 & -- & 2.05 & 8.03 & 18.9 & 250.4 \\
\hline $9 / 21 / 2009(10: 09)$ & 0.096 & 0.093 & 0.88 & 8.06 & 18.6 & 249.8 \\
\hline $9 / 21 / 2009(10: 23)$ & 0.098 & -- & 1.01 & 7.95 & 18.9 & 248.9 \\
\hline $9 / 21 / 2009(10: 37)$ & 0.100 & -- & 0.97 & 7.9 & 18.9 & 249.6 \\
\hline 9/21/2009 (11:38) & 0.097 & -- & 0.44 & 8.1 & 19.4 & 249 \\
\hline $9 / 21 / 2009(13: 38)$ & 0.100 & -- & 0.25 . & 8.13 & 19.8 & 247.9 \\
\hline $9 / 21 / 2009(15: 00)$ & 0.101 & 0.093 & 0.25 & 8.12 & 19.8 & 247.1 \\
\hline $9 / 23 / 2009(12: 30)$ & 0.091 & - & 0.23 & 7.89 & 21.8 & 243 \\
\hline $9 / 24 / 2009(12: 45)$ & 0.095 & -- & 0.14 & 7.9 & 21.6 & 357.7 \\
\hline $9 / 25 / 2009(08: 35)$ & 0.084 & -- & 0.14 & 8.04 & 19.7 & 246 \\
\hline 9/25/2009 (08:35) & 0.084 & -- & 0.14 & 8.04 & 19.7 & 246 \\
\hline $9 / 26 / 2009(08: 45)$ & 0.091 & -- & 0.14 & 7.82 & 20.3 & 244 \\
\hline 9/27/2009 (05:45) & 0.086 & -- & 0.22 & 8 & 19 & 246 \\
\hline 9/29/2009 (14:36) & 0.090 & -- & 0.18 & 7.08 & 21 & 308 \\
\hline $9 / 30 / 2009(10: 00)$ & 0.084 & $\begin{array}{c}0.091 \\
\text { (duplicate } 0.091 \text { ) }\end{array}$ & 0.09 & 7.88 & 22 & 375.1 \\
\hline $10 / 1 / 2009(11: 20)$ & 0.094 & -- & 0.08 & 7.97 & 21.1 & 232.2 \\
\hline 10/2/2009 (07:15) & 0.098 & -- & 0.17 & 7.8 & 19.4 & 235.9 \\
\hline $10 / 3 / 2009(06: 20)$ & 0.090 & -- & 0.14 & 7.93 & 18 & 236.3 \\
\hline $10 / 4 / 2009(07: 00)$ & 0.102 & -- & 1.13 & 8.08 & 19 & 233.3 \\
\hline $10 / 5 / 2009(13: 50)$ & 0.095 & -- & 0.11 & 8.06 & 20.2 & 230.6 \\
\hline $10 / 6 / 2009(10: 51)$ & 0.098 & 0.099 & 0.22 & 7.99 & 20.8 & 228.7 \\
\hline 10/7/2009 (08:35) & 0.097 & -- & 0.15 & 8.02 & 19.1 & 231.3 \\
\hline $10 / 8 / 2009(09: 00)$ & 0.097 & -- & 0.07 & 8.07 & 21.1 & 242.3 \\
\hline 10/9/2009 (08:00) & 0.099 & 0.102 & 0.07 & 7.8 & 20.1 & 230.9 \\
\hline $10 / 10 / 2009(07: 50)$ & 0.102 & -- & 0.08 & 7.98 & 18 & 230.8 \\
\hline
\end{tabular}


SGW-47776, REV. 0

Table B-5. Chemical Sample Data for Constant-Rate Aquifer Test at Well 199-H4-12C

\begin{tabular}{|c|c|c|c|c|c|c|}
\hline $\begin{array}{l}\text { Sample Date } \\
\text { (Time) }\end{array}$ & $\begin{array}{c}\text { Hexavalent } \\
\text { Chromium } \\
\text { (mg/L) }\end{array}$ & $\begin{array}{c}\text { Laboratory Results } \\
\text { for Hexavalent } \\
\text { Chromium } \\
(\mathbf{m g} / \mathbf{L})\end{array}$ & $\begin{array}{c}\text { Turbidity } \\
\text { (NTU) }\end{array}$ & pH & $\begin{array}{l}\text { Temp. } \\
\left({ }^{\circ} \mathrm{C}\right)\end{array}$ & $\begin{array}{c}\text { Cond. } \\
(\mu S / \mathrm{cm})\end{array}$ \\
\hline $10 / 11 / 2009(10: 00)$ & 0.103 & -- & 0.14 & 8.03 & 19.2 & 245 \\
\hline $10 / 12 / 2009(09: 30)$ & 0.101 & -- & 0.07 & 8.01 & 20.5 & 230.5 \\
\hline $10 / 13 / 2009(08: 15)$ & 0.099 & 0.107 & 0.09 & 8.02 & 21.9 & 236.7 \\
\hline $10 / 14 / 2009(08: 55)$ & 0.097 & -- & 0.07 & 8.15 & 20 & 237.4 \\
\hline $10 / 15 / 2009(10: 14)$ & 0.094 & -- & 0.05 & 7.98 & 20.4 & 236.3 \\
\hline $10 / 16 / 2009(06: 00)$ & 0.095 & -- & 0.06 & 8.11 & 19.6 & 235.8 \\
\hline $10 / 17 / 2009(06: 00)$ & 0.104 & -- & 0.03 & 7.72 & 18.7 & 253.5 \\
\hline $10 / 18 / 2009(07: 38)$ & 0.108 & -- & 0.08 & 7.76 & 18.5 & 238.4 \\
\hline $10 / 19 / 2009(08: 34)$ & 0.107 & 0.113 & 0.25 & 8.03 & 20 & 237.1 \\
\hline $10 / 20 / 2009(10: 55)$ & 0.11 & 0.110 & 0.17 & 7.98 & 20.5 & 243 \\
\hline $10 / 21 / 2009(10: 30)$ & 0.108 & -- & 0.37 & 7.84 & 21 & 243 \\
\hline $10 / 22 / 2009(09: 30)$ & 0.112 & - & 0.28 & 7.7 & 20.9 & 246 \\
\hline $10 / 23 / 2009(07: 15)$ & 0.105 & $\begin{array}{c}0.112 \\
\text { (duplicate } 0.111 \text { ) }\end{array}$ & 0.09 & 7.92 & 20.1 & 241 \\
\hline $10 / 24 / 2009(09: 00)$ & 0.103 & -- & 0.34 & 7.95 & 19.5 & 244 \\
\hline $10 / 25 / 2009(06: 30)$ & 0.109 & -- & 0.38 & 7.95 & 20 & 245 \\
\hline $10 / 26 / 2009(09: 40)$ & 0.104 & - & 0.06 & 8.06 & 20.2 & 244 \\
\hline $10 / 27 / 2009(11: 45)$ & 0.102 & -- & 0.36 & 7.96 & 19.8 & 243 \\
\hline $11 / 3 / 2009(15: 05)$ & 0.119 & -- & 0.14 & 7.9 & 20.2 & 326 \\
\hline
\end{tabular}


SGW-47776, REV. 0

Table B-6. Chemical Sample Data for Constant-Rate Aquifer Test at Well 199-H4-15CS

\begin{tabular}{|c|c|c|c|c|c|}
\hline $\begin{array}{c}\text { Sample Date } \\
\text { (Time) }\end{array}$ & $\begin{array}{c}\text { Hexavalent } \\
\text { Chromium } \\
(\mathbf{m g} / \mathbf{L})\end{array}$ & $\begin{array}{c}\text { Turbidity } \\
(\mathrm{NTU})\end{array}$ & $\mathbf{p H}$ & $\begin{array}{c}\text { Temp. } \\
\left({ }^{\circ} \mathbf{C}\right)\end{array}$ & $\begin{array}{c}\text { Cond. } \\
(\boldsymbol{\mu S} / \mathbf{c m})\end{array}$ \\
\hline $10 / 28 / 2009(09: 00)$ & 0.106 & 0.27 & 7.42 & 19.7 & 258.5 \\
\hline $10 / 29 / 2009(09: 20)$ & 0.106 & 0.33 & 7.43 & 19.3 & 261.2 \\
\hline $10 / 30 / 2009(09: 35)$ & 0.105 & 0.27 & 7.7 & 18.9 & 266.5 \\
\hline $10 / 31 / 2009(09: 50)$ & 0.110 & 0.24 & 7.68 & 19.2 & 258.5 \\
\hline $11 / 1 / 2009(10: 05)$ & 0.108 & 0.25 & 7.65 & 19.1 & 258.8 \\
\hline $11 / 2 / 2009(11: 05)$ & 0.103 & 0.25 & 7.8 & 19.7 & 259.1 \\
\hline $11 / 3 / 2009(13: 05)$ & 0.104 & 0.28 & 7.77 & 20.2 & 256.5 \\
\hline
\end{tabular}




\section{Distribution}

$\underline{\text { MS }}$ Quantity

U.S. Department of Energy, Richland Operations Office

DOE Public Reading Room - Onsite

$\mathrm{H} 2-53$

1

CH2M HILL Plateau Remediation Company-Electronic Distribution

$\begin{array}{ll}\text { F. H. Biebesheimer } & \text { R3-60 }\end{array}$

$\begin{array}{ll}\text { D. E. Dooley } & \text { R3-60 }\end{array}$

$\begin{array}{ll}\text { R. S. Edrington } & \text { R3-50 }\end{array}$

$\begin{array}{ll}\text { J. A. Eluskie } & \text { R3-50 }\end{array}$

A. L. Esparza $\quad$ T3-01

$\begin{array}{ll}\text { R. L. Fleshman } & \text { R3-50 }\end{array}$

J. P. Hanson A5-11

$\begin{array}{ll}\text { M. J. Hartman } & \text { R3-50 }\end{array}$

$\begin{array}{lr}\text { A. K. Lee } & \text { R3-60 }\end{array}$

$\begin{array}{ll}\text { J. L. Smoot R3-50 } & \text { R }\end{array}$

$\begin{array}{ll}\text { L. C. Swanson } & \text { R3-50 }\end{array}$

Pacific Northwest National Laboratory-Electronic Distribution

$\begin{array}{ll}\text { F.A. Spane } & \text { K6-96 }\end{array}$

Freestone Environmental Services, Inc.-Electronic Distribution

$\begin{array}{ll}\text { E. A. Garcia } & \text { R3-50 }\end{array}$

Administrative Record $\quad$ H6-08 1

Document Clearance $\quad$ H6-08 1 
SGW-47776, REV. 0

Distr-2 